\title{
EFEITO DE EXTRATOS DE ALBEDO DE LARANJA (Citrus sinensis) DOS INDUTORES DE RESISTÊNCIA ÁCIDO SALICÍLICO, ACILBENZOLAR-S- METIL E Saccharomyces cerevisiae NO CONTROLE DE Phyllosticta citricarpa (TELEOMORFO: Guignardia citricarpa)
}

\section{JÚLIO ALVES CARDOSO FILHO}

Tese apresentada à Escola Superior de Agricultura "Luiz de Queiroz", Universidade de São Paulo, para obtenção do título de Doutor em Agronomia, Área de Concentração: Microbiologia Agrícola.

\section{PIRACICABA}

Estado de São Paulo - Brasil

Fevereiro - 2003 
EFEITO DE EXTRATOS DE ALBEDO DE LARANJA (Citrus sinensis) DOS INDUTORES DE RESISTÊNCIA ÁCIDO SALICÍLICO, ACILBENZOLAR-SMETIL E Saccharomyces cerevisiae NO CONTROLE DE Phyllosticta citricarpa (TELEOMORFO: Guignardia citricarpa)

\author{
JÚLIO ALVES CARDOSO FILHO \\ ENGENHEIRO AGRÔNOMO
}

Orientador: Prof. Dr. SÉRGIO FLORENTINO PASCHOLATI

Tese apresentada à Escola Superior de Agricultura "Luiz de Queiroz", Universidade de São Paulo, para obtenção do título de Doutor em Agronomia, Área de Concentração: Microbiologia Agrícola.

\title{
PIRACICABA
}

\section{Estado de São Paulo - Brasil}

Fevereiro-2003 


\section{Dados Internacionais de Catalogação na Publicação (CIP) DIVISÃO DE BIBLIOTECA E DOCUMENTAÇÃO - ESALQ/USP}

\section{Cardoso Filho, Júlio Alves}

Efeito de extratos de a lbedo de laranja (C itrus sinensis), dos indutores de resistên-cia ácido sa lic îlico, a cilbenzolar-S-metil e Saccharomyces cerevisiae no controle de Phyllosticta citric arpa (Teleomorfo: Guignardia citric a rpa ) / Júlio AlvesCardoso Filho. - Piracicaba, 2003.

125 p. : il.

Tese (doutorado) - Escola Superior de Agricultura Luiz de Queiroz, 2003. Bibliografia.

1. Controle integrado 2. Extrato vegetal 3. Fungo patogênico 4. Laranja 5. Mancha-preta-dos-citros 6. Resistência a doença I. Título 


\section{À DEUS,}

pela oportunidade da vida,

Aos meus pais Júlio e Eunice Cardoso

(In memoria),

Aos meus pais de criação, Irene e Edvaldo,

os grandes responsáveis pela minha formação,

À minha querida esposa Tania, companheira e amiga

de todas as horas, pela paciência, apoio, incentivo e

amor, especialmente nos momentos difíceis,

Aos meus filhos Yuri e Natasha,

razão de alegria perene,

\section{DEDICO}

Aos meus familiares,

À todos que direta ou

indiretamente contribuíram

para com a realização deste trabalho,

\section{OFEREÇO}




\section{AGRADECIMENTOS}

Agradeço a todos os colegas, professores e funcionários do Setor de Fitopatologia do Departamento de Entomologia, Fitopatologia e Zoologia Agrícola da ESALQ/USP, que contribuíram para a realização deste trabalho, e em especial:

Ao Prof. Dr. Sérgio Florentino Pascholati pela valiosa oportunidade fornecida, incentivo, orientação, paciência, ajuda, confiança e amizade.

Ao meu amigo Marcel Sposito Belloto (Fundecitrus), pelo apoio, sugestões, colaboração, e amizade em todas as fases de realização deste trabalho.

Ao Pesquisador Carlos Ivan Aguilar-Vildoso (IAC-Estação de Citricultura de Cordeirópolis-SP), pela sugestões e colaboração.

Ao meu amigo Rodrigo Facchini Magnani (Laboratório de Espectrometria de Massas (LEM-DQ) - Departamento de Química - UFSCar ), pelas sugestões e colaboração na fase final do trabalho.

Aos amigos e colegas André, Eduardo, Elaine, Cândido, Daniel, Leonardo, Ivan, Marissônia, Nelson, Nívea, Renata, Robson, Patrícia e Solange pelas sugestões, colaboração, incentivo e carinho e amizade.

Aos funcionários e amigos do Departamento de Entomologia, Fitopatologia e Zoologia, Sílvia, Marise, Edivaldo, Jérfeson, Marina e seu Pedro.

A minha amiga, Prof. Dra. Tânia Marta (CECA/FIT/UFAL), pelo incentivo, apoio e amizade.

Ao Prof. Dr. Hiroshi Kimati, pelas sugestões e colaboração.

A todos os professores do CECA/FIT/UFAL, que incentivaram a minha saída para a realização do doutorado.

A CAPES, pela cessão da bolsa de estudos.

A todos membros da União Espírita de Piracicaba, pelo apoio, carinho e amizade.

A Deus pela presença constante, inspiração e força sempre mantidas.

E finalmente, a Universidade Federal de Alagoas (UFAL) e ao Deparatmento de Fitotecnia e Fitossanidade (FIT) pela minha liberação integral durante estes quatro anos. 


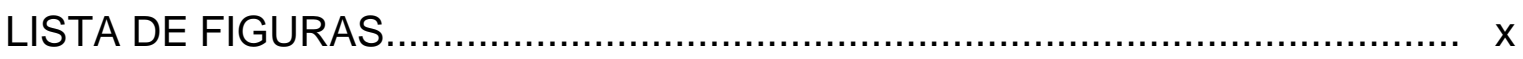

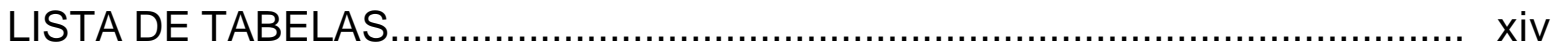

LISTA DE APÊNDICES.......................................................................

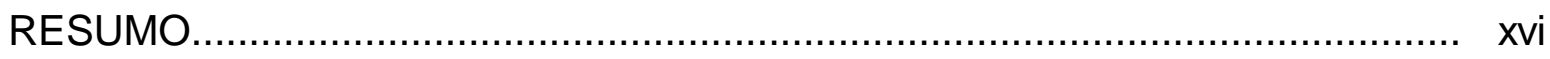

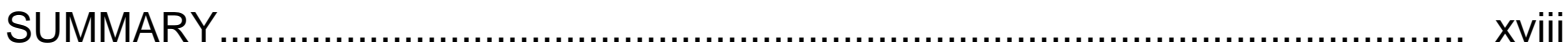

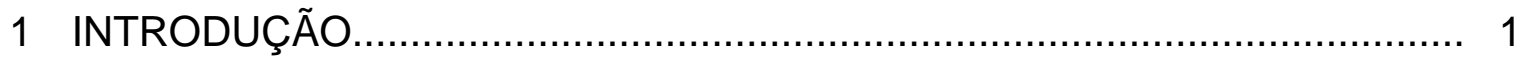

2 REVISÃO DE LITERATURA ............................................................... 3

2.1 Mancha preta dos citros......................................................................... 3

2.1.1 Ocorrência............................................................................. 3

2.1.2 Patógeno e hospedeiros............................................................. 4

2.1.3 Sintomatologia e epidemiologia .......................................................... 4

2.1.4 Medidas de controle................................................................... 9

2.2 Infecções latentes e quiescentes em doenças de pós-colheita.................... 9

2.2.1 A quiescência durante a germinação do esporo e alongamento de

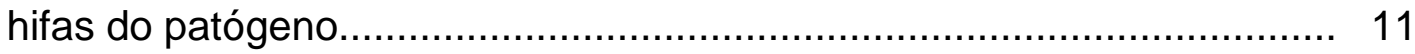

2.2.2 Quiescência durante a formação do apressório..................................... 12

2.2.3 Quiescência do apressório, formação da hifa de germinação e hifa

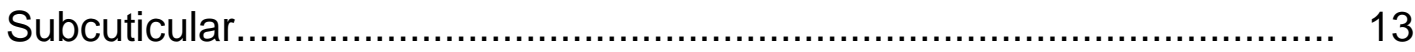

2.2.4 Mecanismos da quiescência.......................................................... 14

2.2.4.1 Fatores que afetam a quiescência de esporos germinados e não germinados............................................................................ 14 
2.2.4.2 Quiescência na formação de apressório

2.2.4.3 Quiescência durante a penetração das hifas e colonização do hospedeiro.

2.3 Indução de resistência em plantas contra patógenos................................ 18

2.3.1 Princípios da indução de resistência...................................................... 20

2.3.2 Alguns mecanismos de defesa induzidos exibidos pela planta resposta ao ataque de patógenos.

2.3.2.1 Proteínas vegetais relacionadas àpatogênese (proteínas-RP).

2.3.2.2 Fitoalexinas

2.3.3 Alguns sinais envolvidos na indução de resistência sistêmica a patógenos em plantas.

2.3.3.1 Ácido salicílico e seus derivados.

2.3.3.2 Jasmonatos e seus derivados..................................................... 26

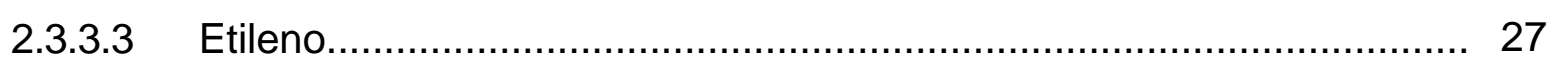

2.3.4 Indutores de resistência em vegetais................................................ 27

2.3.4.1 Indutores bióticos....................................................................... 27

2.3.4.2 Indutores bióticos........................................................................ 28

2.3.5 Potencial da indução de resistência no controle de doenças de plantas..

$2.4 \quad$ Compostos fenólicos...................................................................... 31

2.4.1 Compostos fenólicos em citros........................................................ 31

2.4.2 O papel dos compostos fenólicos na resistência de plantas às doenças.

3 EFEITO DE EXTRATOS DO ALBEDO DE Citrus sinensis NA GERMINAÇÃO E CRESCIMENTO MICELIAL DE Phyllosticta citricarpa in vitro

Resumo. 
3.1 Introdução.

3.2 Material e métodos.

3.2.1 Obtenção e extração dos extratos do albedo

3.2.2 Patógeno.

3.2.3 Análise qualitativa para compostos fenólicos do albedo.

3.2.4 Análise quantitativa do conteúdo total de compostos fenólicos do albedo e flavedo.

3.2.5 Detecção da atividade antifúngica dos extratos.

3.2.5.1 Influência na germinação de picnidiósporos e formação de apressório.

3.2.5.2 Influência no crescimento micelial.

3.2.5.3 Influência na formação de picnídios em folhas autoclavadas

3.2.5.4 Análise cromatográfica dos extratos e detecção da atividade antifúngica

3.2.5.5 Análise estatistica.............................................................. 51

3.3 Resultados e discussão................................................................ 51

3.3.1 Análise qualitativa para compostos fenólicos do albedo......................... 51

3.3.2 Análise quantitativa do conteúdo total de compostos fenólicos do albedo e flavedo.

3.3.3 Detecção da atividade antifúngica dos extratos.

3.3.4 Influência na germinação de picnidiósporos e formação de apressório.

3.3.5 Influência no crescimento micelial.................................................. 61

3.3.6 Influência na formação de picinídios em folhas autoclavadas.

3.3.7 Análise cromatográfica dos extratos e detecção da atividade antifúngica.

3.4 Conclusões.

4 Guignardia citricarpa EM LARANJA: BION®, ÁCIDO SALICÍLICO E Saccharomyces cereviseae não controlam o patógeno 
Resumo

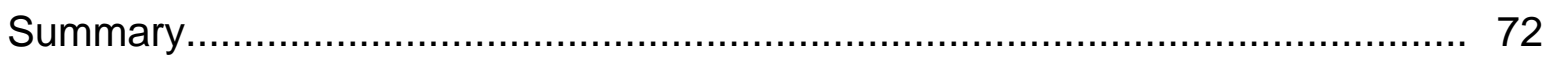

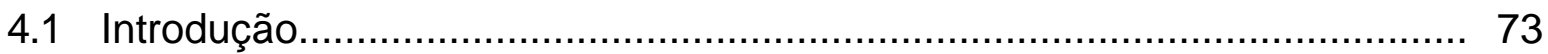

4.2 Material e métodos.................................................................... 74

4.2.1 Indução de resistência em pós-colheita.............................................. 74

4.2.2 Indução de resistência em pré-colheita................................................. 75

4.2.3 Influência dos indutores na germinação de picnidiósporos e formação

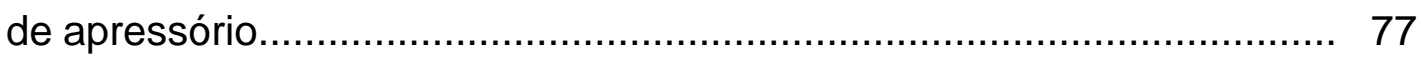

4.2.4 Delineamento experimental e avaliação estatística................................ 78

4.3 Resultados e discussão.................................................................. 78

4.3.1 Indução de resistência em pós-colheita............................................... 78

4.3.2 Indução de resistência em pré-colheita................................................ 84

4.3.3 Influência dos indutores na germinação de picnidiósporos e formação

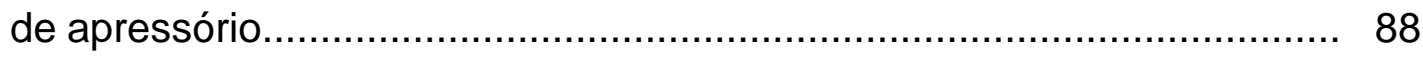

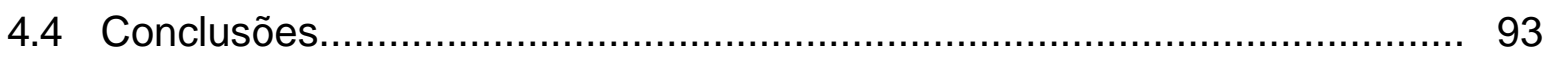

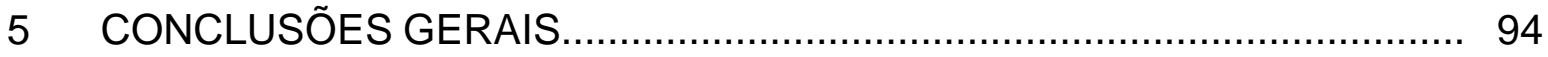
REFERÊNCIAS BIBLIOGRÁFICAS................................................... 95

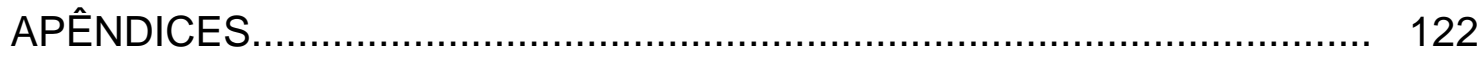


1 Mancha preta dos citros (MPC), observados nos frutos em condições de campo. Mancha sardenta (A), Mancha dura ou preta (B), Falsa melanose (C) e Mancha virulenta (D). Fotos $1 \mathrm{C}$ e 1 D obtidas de Fundecitrus (2000)

2 Germinação de picnidiósporos e formação de apressório de $P$. citricarpa (fase teleomórfica Guignardia citricarpa) em água destilada esterilizada, a partir de picnídios formados em folhas autoclavadas de limão Siciliano Massa de picnidiósporos na superfície do ostíolo do picnídio de $P$. citricarpa (A); Picnidiósporos não germinados de $P$. citricarpa (B); Seqüência de eventos durante a germinação de picnidiósporos e formação de apressório de $P$. citricarpa $(\mathrm{C}-\mathrm{F})$. Dimensões dos picnidiósporos 12,3 x 6,2 $\mu \mathrm{m}$. Figura $2 \mathrm{~A}$ (aumento de $100 \mathrm{x}$ ), $2 \mathrm{~B}-2 \mathrm{~F}$ (aumento de $400 \mathrm{x}$ ).

3 Corte transversal em fruto de laranja Pêra-Rio com sintoma de MPC, do tipo mancha virulenta, destacando a restrição do patógeno $P$. citricarpa ao flavedo (f), casca ou epicarpo, permanecendo o albedo (a) ou mesocarpo intacto. B - Detalhe na lesão da presença de picnídios de $P$. citricarpa. C - Detalhe da presença de picnidióporos de P. citricarpa (x 1950). Barra 4 $\mathrm{mm}$

4 Efeito de extratos (aquoso, etanólico, metanólico) dealbedo de laranja Pêra-Rio, na germinação de picnidiósporos de $P$. citricarpa. Os valores representam a média (seis repetições) dos dados percentuais observados, em relação ao total de 100 picnidiósporos, após $12 \mathrm{~h}$ de incubação à $26{ }^{\circ} \mathrm{C}$ em câmara de crescimento. As concentrações foram obtidas a partir de solução-estoque contendo $100 \mathrm{mg}$ de extrato de albedo liofilizado / $\mathrm{mL}$ de água destilada esterilizada. 
5 Efeito de extratos (aquoso, etanólico, metanólico) de albedo de laranja Pêra-Rio, na formação de apressórios de picnidiósporos de $P$. citricarpa. Os valores representam a média (seis repetições) dos dados percentuais observados, em relação ao total de 100 picnidiósporos, após $12 \mathrm{~h}$ de incubação à $26{ }^{\circ} \mathrm{C}$ em câmara de crescimento. As concentrações foram obtidas a partir de solução-estoque contendo $100 \mathrm{mg}$ de extrato de albedo liofilizado / $\mathrm{mL}$ de água destilada esterilizada. Foram considerados como formados os apressórios de comprimento iqual ou superior ao tamanho do picnidiósporo

6 Percentagem de inibição do crescimento micelial de $P$. citricarpa aos 15 dias, por extrato (aquoso, etanólico e metanólico) liofilizado de albedo de laranja Pêra-Rio. Os valores representam a média (seis repetições) de 4 medidas do diâmetro da colônia por repetição. O fungo foi crescido a 26 ${ }^{\circ} \mathrm{C}$, sob luz fluorescente, com alternância de luminosidade (12 h claro/ 12 $\mathrm{h}$ escuro). As concentrações dos extratos foram obtidas de soluçãoestoque contendo $100 \mathrm{mg}$ de extrato de albedo liofilizado / $\mathrm{mL}$ de água destilada esterilizada.

7 Efeito de água destilada esterilizada (A), da concentração albedo de laranja Pêra-Rio (100 (0\%); 4 (25\%); 2 (50\%); 1,3 (75\%) e 1 (100\%) mg $\mathrm{mL}^{-1}$ em água destilada esterilizada, v/v) (B) e benomil (C) $(0,35 \mathrm{~g}$ do p.a. $\left.\mathrm{L}^{-1}\right)$ na formação in vitro de picnídios de Phyllosticta citricarpa (teleomorfo: Guignardia citricarpa) em folhas de limão Siciliano autoclavadas.

8 Espéctro ultra violeta de absorção dos eluentes de extratos (200 mg mL $\mathrm{m}^{-1}$ $\mathrm{H}_{2} \mathrm{O}$ ) liofilizados metanólicos $(\mathrm{MeOH})$, etanólicos $(\mathrm{EtOH})$ e aquosos $\left(\mathrm{AqH}_{2} \mathrm{O}\right)$ de albedo de laranja Pêra-Rio em placas de sílica gel $\left(\mathrm{SiO}_{2} \mathrm{x}\right.$ $\mathrm{H}_{2} \mathrm{O} 20 ; 20 \mathrm{~cm}$; G $60 \mathrm{~F}_{250 \mathrm{~nm}}$ (Whatman) com indicador de luminescência através de cromatrografia de camada delgada (fase móvel: butanol, ácido acético, água; $4: 1: 1 ; \mathrm{v} / \mathrm{v} / \mathrm{v})$. Comprimento de onda máximo para $\mathrm{MeOH}=308,2$ e 278,7; $\mathrm{EtOH}=306,3$ e 276,9; $\mathrm{AqH}_{2} \mathrm{O}=307,9$ e 277,6. ABS = absorbância

9 Espéctro ultra violeta de absorção de eluentes das zonas de inibição 1 e 2 obtidas a partir da bioautografia com Penicillium digitatum em placas de sílica gel $\left(\mathrm{SiO}_{2} \times \mathrm{H}_{2} \mathrm{O} 20 ; 20 \mathrm{~cm}\right.$; $\mathrm{G} 60$ F $254 \mathrm{~nm}$ (Whatman) com indicador de luminescência em cromatrografia de camada delgada. Fase móvel butanol / ácido acético / água $(4: 1: 1, \mathrm{v} / \mathrm{v} / \mathrm{v})$. Os eluentes foram visualizados sob luz ultra violeta (365 e $254 \mathrm{~nm})$ antes da bioautografia..... 
10 Escala diagramática para avaliação da mancha preta dos citros (MPC) causada por Guignardia citricarpa em folhas de limão Siciliano (Citrus limonia) com cinco níveis de severidade da doença. (Noronha, 2003)

11 Efeito de ácido salicílico em pós-colheita, aplicado em frutos sintomáticos de laranja (var. Pêra-Rio), em diferentes concentrações e tempos de exposição. Ethrel aplicado $72 \mathrm{~h}$ antes e depois do indutor. 20

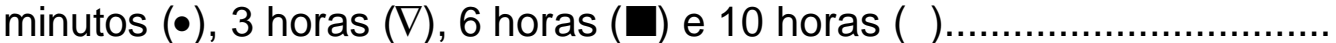

12 Efeito de Bion em pós-colheita, aplicado em frutos sintomáticos de laranja (var. Pêra-Rio), em diferentes concentrações e tempos de exposição. Ethrel aplicado $48 \mathrm{~h}$ antes e depois do indutor.20 minutos $(\bullet), \quad 3$ horas $(\nabla), \quad 6$ horas $(\square)$ e 10 horas

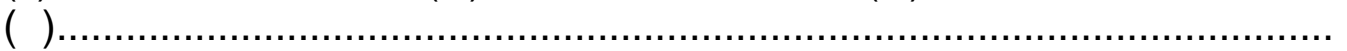

13 Efeito de Saccharomyces cerevisiae em pós-colheita, aplicado em frutos sintomáticos de laranja (var. Pêra-Rio), em diferentes concentrações e tempos de exposição. Ethrel aplicado $24 \mathrm{~h}$ antes e depois do indutor. 20 minutos $(\bullet), \quad 3$ horas $(\nabla), 6$ horas $(\square)$ e 10 horas ( )

14 Efeito de Bion no progresso da mancha preta dos citros em folhas de limão Siciliano (Citrus limonia), infectadas naturalmente a campo por Guignardia citricarpa. Dados médios de avaliação conduzida durante os meses de março de 2001 a setembro de 2002

15 Efeito de $S$. cerevisiae no progresso da mancha preta dos citros em folhas de limão Siciliano (Citrus limonia), infectadas naturalmente a campo por Guignardia citricarpa. Dados médios de avaliação conduzida durante os meses de março de 2001 a setembro de 2002.

16 Efeito in vitro de ácido salicílico na germinação de picnidiósporos e formação de apressório por Phyllosticta citricarpa após $12 \mathrm{~h}$ de incubação a $26{ }^{\circ} \mathrm{C}$, sob luz fluorescente constante.Germinação ( ), apressório $(\nabla)$

17 Efeito in vitro de Bion na germinação de picnidiósporos e formação de apressório por Phyllosticta citricarpa após $12 \mathrm{~h}$ de incubação a $26^{\circ} \mathrm{C}$, sob luz fluorescente constante. Germinação ( ),apressóri $(\nabla)$ 
18 Efeito in vitro de Saccharomyces cerevisiae na germinação de picnidiósporos e formação de apressório por Phyllosticta citricarpa após $12 \mathrm{~h}$ de incubação a $26^{\circ} \mathrm{C}$, sob luz fluorescente constante. Germinação

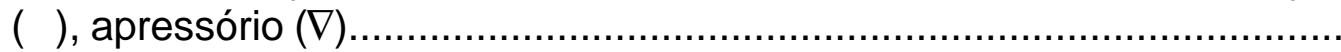


1 Exemplos de infecções quiescentes em frutos e o estádio de desenvolvimento do patógeno em que a infecção foi constatada.

2 Análise quantitativa do teor de fenóis totais, quantificados usando o reagente de Folin-Ciocalteau, em extrato aquoso,etanólico e metanólico de albedo de laranja, variedades Pêra-Rio, Valência e Natal.

3

Análise quantitativa de fenóis totais usando o reagente de FolinCiocalteau no flavedo (com e sem sintoma de MPC) e albedo de 54 laranja Pêra-Rio.

4 Efeito da concentração de extrato de albedo de Citrus sinensis (var. PêraRio), benomil[ e água destilada esterilizada na formação in vitro de picnídios de $P$. citricarpa, em folhas autocladas de limão Siciliano, após 18 dias a $26^{\circ} \mathrm{C}$ em câmara de crescimento com alternância de luminosidade ( $12 \mathrm{~h}$ claro e $12 \mathrm{~h}$ escuro, luz fluorescente)...

5 Efeito da concentração de extrato de albedo de Citrus sinensis (var. PêraRio), benomil[ e água destilada esterilizada na formação in vitro de picnídios de $P$. citricarpa, em folhas autocladas de limão Siciliano, após 18 dias a $26^{\circ} \mathrm{C}$ em câmara de crescimento com alternância de luminosidade (12 h claro e $12 \mathrm{~h}$ escuro, luz fluorescente)

6 Dados climatológicos ${ }^{1}$ e de dispersão de ascósporos ${ }^{2}$ de Guignardia citricarpa observados durante os meses de permanência das mudas de limão Siciliano na Fazenda Bela Vista em Conchal-SP 
1 Curva padrão para dosagem de compostos fenólicos pelo método do Reagente de Folin-Ciocalteau.

2 Fluxograma para obtenção de extratos do albedo de laranja Pêra-Rio. O albedo foi submetido àextração com solventes e mistura dos mesmos visando obter extratos com diferentes polaridades (Magnani et al., 2002). Os extratos foram submetidos àHPLC, espectrometria de massas e $\mathrm{RMN}-{ }^{13} \mathrm{C}$ onde foi identificado o flavonóide glicosilado naringina.

3 Espéctro de absorção em ultra violeta de eluente de naringina cromatografado em placas de sílica gel $\left(\mathrm{SiO}_{2} \times \mathrm{H}_{2} \mathrm{O} 20 ; 20 \mathrm{~cm} ; \mathrm{G} 60 \mathrm{~F}_{250}\right.$ $\mathrm{nm}$ (Whatman)) com indicador de luminescência obtido através de cromatrografia de camada delgada (fase móvel butanol, ácido acético, água; $4: 1: 1 ; \mathrm{v} / \mathrm{v})$.

4

Coeficientes de determinação para os efeitos de indução de resistência de ácido salicílico, Bion e Saccharomyces, cerevisiae, antes e depois do uso de Ethrel, em frutos de laranja (Citrus sinensis, var. Pêra-Rio) sintomáticos e assintomáticos infectados por Phyllosticta 126 citricarpa. 


\title{
EFEITO DE EXTRATOS DE ALBEDO DE LARANJA (Citrus sinensis) DOS INDUTORES DE RESISTÊNCIA ÁCIDO SALICÍLICO, ACILBENZOLAR-S- METIL E Saccharomyces cerevisiae NO CONTROLE DE Phyllosticta citricarpa (TELEOMORFO: Guignardia citricarpa)
}

\author{
Autor: JÚLIO ALVES CARDOSO FILHO \\ Orientador: Prof. Dr. SÉRGIO FLORENTINO PASCHOLATI
}

RESUMO

A mancha preta dos citros (MPC) é uma doença que limita a exportação de laranja brasileira para o Japão e países da Europa. Exceto para Citrus aurantium e seus híbridos, todas as outras variedades são susceptíveis ao patógeno. O fungo Guignardia citricarpa, descoberto por Kiely em 1948 em New South Wales na Austrália, é o estádio sexual do agente causal da MPC e a sua fase imperfeita é Phyllosticta citricarpa. Uma importante característica da MPC é seu longo período de latência. A infecção pode ser efetuada por ascósporos e picnidiósporos. A lesão nos frutos fica restrita ao flavedo (epicarpo), sendo que o fungo não infecta o albedo (mesocarpo). O albedo é rico em celulose, carboidratos solúveis, pectinas, compostos fenólicos (flavonóides), aminoácidos e vitaminas. Os compostos fenólicos presentes nas plantas são produtos do metabolismo secundário, e podem ser resultantes da 
interação planta-ambiente e podem sintetizados como resposta ao ataque de fitopatógenos. Os fenólicos presentes nos citros incluem flavonóides, antocianinas, coumarinas e psorolenos entre outros. Estes compostos podem exibir ação antimicrobiana e antiviral e podem contribuir controle da MPC. A aplicação de fungicidas é o método de controle da MPC. Uma outra possibilidade de controle seria a ativação de fatores de resistência através do uso de indutores bióticos (Saccharomyces cerevisiae) e abióticos (Bion e ácido salicílico). Deste modo, este trabalho teve como objetivos estudar os efeitos do uso de extratos aquosos, metanólicos e etanólicos de albedo de laranja na germinação formação de apressório e crescimento micelial de $P$. citricarpa in vitro, bem como avaliar o uso da indução de resistência para o controle da MPC através dos indutores $S$. cerevisiae, Bion e ácido salicílico em pós e pré-colheita em frutos de laranja 'Pêra-Rio' e folhas de limão 'Siciliano'. Os resultados experimentais mostraram que os extratos de albedo, nas concentrações de $10 \mathrm{e}$ $100 \mathrm{mg} / \mathrm{mL}$ de água, foram capazes de inibir em 100\% a germinação, formação de apressório e o crescimento micelial de $P$. citricarpa. Foi observado que os extratos, dependendo da concentração, podem ter ação fungicida ou fungistática. No tocante a utilização de $S$. cerevisiae, Bion e ácido salicílico, aplicados em pós-colheita, foi observado que estes agentes não foram capazes de impedir o desenvolvimento de novas lesões em frutos de laranja 'Pêra-Rio'. Também foi constatado que $S$. cerevisiae e Bion, aplicados em pré-colheita, não foram capazes de induzir resistência contra $P$. citricarpa em folhas de limão 'Siciliano' inoculadas previamente a campo com G. citricarpa. Nesse sentido, sugere-se que outros estudos sejam conduzidos, principalmente no que se refere ao uso potencial de extratos do albedo de laranja como medida alternativa de controle da MPC. 


\title{
THE EFFECT OF ORANGE (Citrus sinensis) ALBEDO EXTRACTS THE RESISTANCE INDUCERS WITH SALICYLIC ACID, ACILBENZOLAR-S- METHYL AND Saccharomyces cerevisiae ON THE CONTROL OF Phyllosticta citricarpa (TELEOMORPH: Guignardia citricarpa)
}

\author{
AUTHOR: JÚLIO ALVES CARDOSO FILHO \\ AdVISER: PROF. DR. SÉRGIO FLORENTINO PASCHOLATI
}

\section{SUMMARY}

Black spot of citrus (CBS) has been a limiting factor in the export of brazilian oranges to Japan and European countries and Japan. Except for Citrus aurantium and its hybrids, all commercially growing Citrus spp. are susceptible to the pathogen. The fungus Guignardia citricarpa, discovered by Kiely in 1948 in New South Wales, is the sexual stage of the causal agent of CBS and Phyllosticta citricarpa is the imperfect stage. An important characteristic of CBS is the long latent period after infection. The infection is carried out by ascospores and pycnidiospores. The fungicidal application is the most important method of control of CBS. The CBS lesion in citrus fruits is limited to the flavedo, since $P$. citricarpa does not infect the albedo. The albedo is rich in cellulose, soluble carbohydrates, pectin, phenolic compounds, amino acids and vitamins. The phenolics present in the plants are secondary 
metabolic products and are believed to be produced as a result of the plant interaction with the enviromment and synthesized as a response to attempted phytopathogen attacks. The phenolics that occur in Citrus include flavonoids, anthocyanins, coumarins and psorolens. These compounds may exhibit antiviral and antimicrobial activities, and may contribute to the control of CBS disease. An another possibility to the CBS control is the activation of factors resistance by the use of abiotics (Bion and salicylic acid) and biotics (Saccharomyces cerevisiae) "plant defence activator" (inducers). Therefore, the objectives of this paper were to study the in vitro effects of aqueous, ethanolic and methanolic albedo orange extracts on the germination, appressorium formation and mycelial growth of $P$. citricarpa as well as to evaluate the use of the $S$. cerevisiae, Bion and salicylic acid as "plant defence activator" at post and preharvest conditions in fruit of "Pêra-Rio" and leaves of 'Siciliano' lemon. The results showed that the use of albedo extracts, 10 and $100 \mathrm{mg}$ per $\mathrm{mL}$ of water, inhibited $100 \%$ the germination, appressorium formation and mycelial growth of $P$. citricarpa. It was also observed that the extracts of albedo, depending upon the concentration, exhibited fungicidal or fungistatic activity. The use of $S$. cerevisiae, Bion and salicylic acid at postharvest conditions did not affect the development of new lesions of CBS in 'Pêra-Rio' orange fruit. It was also observed that the use of $S$. cerevisiae and Bion at preharvest conditions, did not induce resistance against $P$. citricarpa in leaves of 'Siciliano' lemon naturally infected with $G$. citricarpa under field conditions. Thus, it is suggested that other studies be carried out, mainly regarding the potential of orange albedo's extracts as a alternative method for CBS control. 


\section{INTRODUÇÃO}

O fungo Guignardia citricarpa (fase anamórfica ou imperfeita: Phyllosticta citricarpa) é o agente causal da mancha preta dos citros (MPC) e pode infectar folhas e frutos por meio de seus dois tipos de esporos, os esporos assexuais (picnidiósporos) que se desenvolvem em frutos e folhas fixadas à planta e os esporos sexuais (ascósporos), que se desenvolvem nas folhas em decomposição no solo (Feichtenberger, 1996; Fundecitrus, 2000; Kotzé, 1981; 1996).

Em função da importância da MPC em citros e os preços praticados no mercado nacional e internacional para as frutas cítricas, medidas de controle economicamente mais viáveis que o controle químico através do uso de fungicidas protetores ou sistêmicos devem ser encontradas (Feichtenberger, 1996). Dentro deste contexto, podemos incluir o controle não convencional, também chamado de alternativo (Bettiol, 1991), o qual englobaria as medidas de controle que não incluem o controle químico clássico e o melhoramento genético de plantas para resistência às doenças (Cook \& Baker, 1983; Pascholati, 1998), como um dos possíveis caminhos para o controle da MPC.

De acordo com Pascholati (1998), o controle alternativo envolveria o controle biológico e a indução de resistência em plantas, embora muitos autores prefiram incluir a indução de resistência sob o âmbito do controle biológico. Além do uso da indução de resistência como possibilidade de controle alternativo da MPC, inúmeros trabalhos atestam o potencial de extratos vegetais direta (Ribeiro \& Bedendo, 1999; Stangarlin et al.,1999) ou 
indiretamente induzindo o acúmulo de fenóis (Musumeci \& Oliveira, 1975) e fitoalexinas (Hipskind et al., 1990) em tecidos vegetais infectados com fitopatógenos. Estes métodos de controle alternativos são viáveis e desejáveis quando comparados com o controle tradicional, principalmente por não deixarem resíduos tóxicos, quando aplicados em pré ou pós colheita (Kretzschmar, 1991).

O potencial de uso de extrato do albedo e do flavedo de laranja, na inibição de Phomopsis citri in vitro foi relatado pela primeira vez em 1964, por El-Tobshy \& Sinclair, quando evidenciou-se que o uso dos mesmos, isoladamente ou em combinação, era efetivo na inibição do crescimento micelial do fungo.

Assim sendo, este trabalho teve como objetivos: estudar os efeitos do uso de extratos de albedo de laranja na germinação e esporulação de $P$. citricarpa in vitro, bem como estudar a viabilidade da indução de resistência, como medida alternativa, para o controle da mancha preta em citros, pelo uso do agente biótico Saccharomyces cerevisiae e dos abióticos Bion e ácido salicílico. 


\section{REVISÃO DE LITERATURA}

\subsubsection{Mancha preta dos citros}

\subsubsection{Ocorrência}

A mancha preta dos frutos cítricos foi constatada pela primeira vez na Austrália, no ano de 1895, causando prejuízos elevados à produção, tanto plantas em pomares como em frutos em pós-colheita (Sutton \& Waterson, 1966). Foram constatados prejuízos de milhões de dólares em varias regiões produtoras de citros no mundo (Calavan, 1960), com perdas superiores a $80 \%$ em várias áreas de produção na Austrália e África do Sul (Klotz, 1978). Além destes países, sua ocorrência também já foi relatada em Moçambique, China, Taiwan, Indonésia, Japão, Argentina e Peru (Sutton \& Waterson, 1966).

No Brasil, a mancha preta foi descrita, inicialmente, a partir de frutas cítricas de uma feira livre no município de Piracicaba, no Estado de São Paulo, em 1940 (Averna-Saccá, 1940), sem, no entanto, ter sido mencionada a sua importância em termos de perdas. A doença permaneceu esquecida durante vários anos, certamente devido a uma temporária redução do inóculo, resultante da epidemia da tristeza do citros, que redundou na eliminação aproximada de cerca de 11 milhões de árvores nas décadas de 30 a 40 (Góes, 1998). Na década de 80, a doença foi relatada no Estado do Rio de Janeiro (baixada fluminense), causando perdas consideráveis em "Tangerina Rio" (Robbs et al., 1980) e, atualmente, também tem ocorrido em frutos de laranjas 'Lima', 'Seleta', 'Folha Murcha', 'Natal', 'Pêra' e 'Valência' (Góes et al.,1990). Em 
1992, novas constatações do fungo foram feitas no Estado de São Paulo, causando severos prejuízos em pomares localizados na região dos municípios de Conchal e Mogi-Guaçu (Góes \& Feichtenberger, 1993). Em 1986, foi encontrada no Estado do Rio Grande do Sul (Vale da Cal) causando sérios prejuízos para a citricultura daquela região (Góes et al., 1988; Góes et al., 1991).

\subsubsection{Patógeno e hospedeiros}

O fungo causador da mancha preta dos frutos cítricos foi primeiramente descrito por McAlpine, em 1889 (Mconie, 1964) na sua forma assexuada, e recebeu a designação de Phoma citricarpa McAlpine. Posteriormente, surgiram duas novas propostas para a recombinação do binômio: Phyllosticta citricarpa (McAlpine) Petrak. e Phyllostictina citricarpa (Mc Alpine) Petrak., ambas, segundo Robbs (1990) adotadas indistintamente pelos fitopatologistas. O estágio sexual do patógeno foi descoberto por Kiely, em 1948, e foi chamado de Guignardia citricarpa Kiely (Kotzé, 1981, 1996). No ano de 1964, McOnie descreveu duas variantes de G. citricarpa, morfologicamente idênticas, que ocorriam em citros, sendo apenas uma delas patogênica, e a outra endofítica. Entretanto, atualmente, sabe-se que a forma endofítica é uma outra espécie denominada de Guignardia mangiferae (anamófica: Phyllosticta capitalensis), de acordo com Baayen et al. (2002).

Com exceção da laranja azeda (C. aurantium L.) e seus híbridos, todas as espécies de Citrus são susceptíveis. Os limoeiros também são susceptíveis e grandes perdas podem ocorrer em laranja doce (C. sinensis) e pomelo (C. paradisi Macf.) (Kotzé, 1981, 1996).

\subsubsection{Sintomatologia e epidemiologia}

Uma característica interessante da mancha preta é que o fungo pode estar presente em uma área por muitos anos, antes dos sintomas 
aparecerem. Às vezes, pode levar de 5 a 30 anos para os primeiros sintomas serem percebidos e a doença pode atingir proporções epidêmicas (Kotzé, 1981; 1996).

Os sintomas observados nas folhas são lesões caracterizadas pela formação de um centro acinzentado com bordos salientes marrom-escuros e um halo amarelo ao redor, parecido com os sintomas encontrados nos frutos. As lesões em folhas são, freqüentemente, encontradas em tangerinas e limoeiros verdadeiros (Fundecitrus, 2000).

Os primeiros sintomas aparecem no início da maturação dos frutos, o que é muito tarde para qualquer tentativa de controle (Góes et al., 1990). Um longo período de latência (dormência ou quiescência), de seis a oito meses a depender da variedade, caracteriza esta doença (Góes, 1998; Whiteside et al., 1993). Este período termina quando o fruto amadurece, entretanto os mecanismos envolvidos na manifestação de sintomas ainda não são compreendidos, porém podem resultar do aumento da temperatura quando o fruto está maduro ou próximo àmaturidade (Mconie, 1964) e do aumento da intensidade luminosa (Brodrick \& Rabie, 1970).

A fase perfeita do fungo desenvolve-se em folhas caídas no chão, formando peritécios dos quais são liberados os ascósporos, considerados por Klotz (1973) os principais responsáveis pela disseminação da doença, podendo atingir plantas até $25 \mathrm{~km}$ de distância. Nos frutos, no interior das lesões, são observados picnídios que produzem os picnidiósporos, os quais têm sua disseminação facilitada pela água, e são os principais responsáveis pela disseminação dentro de uma mesma planta (Kotzé, 1981,1996). As lesões de mancha preta nos frutos normalmente são circulares, com poucos milímetros de diâmetro, e não se estendem para mais do que poucas camadas de células dentro da área do albedo (Kotzé, 1981, 1996; Mconie, 1967).

Os sintomas observados nos frutos (Figura 1) podem ser agrupados da seguinte forma (Fundecitrus, 2000): 
- Falsa melanose: os sintomas são semelhantes aos da melanose dos citros, diferindo pelo fato de que, ao contrário da melanose, as lesões não são ásperas. As lesões são pequenas, com cerca de $2 \mathrm{~mm}$, rodeadas por pontos pequenos com aproximadamente $1 \mathrm{~mm}$ de diâmetro. Este sintoma ocorre em frutos em desenvolvimento, normalmente, a partir de março-abril;

- Mancha preta: é o sintoma mais comum da doença, caracterizando-se por lesões deprimidas, de bordos bem definidos, com centro acinzentado, contendo frutificações (picnídios); ocorre principalmente na fase de transição do fruto verde para maduro. Em frutos verdes, as lesões apresentam um círculo amarelo ao seu redor. Frutos colhidos e infectados, embora não apresentem sintomas aparentes, podem desenvolvê-los durante o transporte ou armazenagem, não exibindo áreas deprimidas e pontuações negras;

- Mancha marrom ou mancha sardenta: são lesões pequenas de coloração pardo-avermelhadas, levemente deprimidas, com bordos definidos, formato irregular, normalmente sem apresentar as frutificações do fungo. Ocorrem após início da maturação dos frutos, sendo quase invisíveis a olho nu e podendo coalescer originando lesões parecidas com as formadas pela melanose. Sob condições favoráveis de temperatura e luminosidade podem dar origem àmancha virulenta;

- Mancha virulenta: caracteriza-se pela formação de lesões grandes, escuras ou de coloração marrom, deprimidas, com ou sem frutificações, de formato irregular, podendo ocupar áreas de vários centímetros quadrados, sendo deprimidas ou não. O centro possui cor cinza a as bordas são salientes, marrom escura ou vermelha escura, com ou sem frutificações. Pode ser resultante da evolução das manchas pretas e aparecem, em geral, no final da safra, quando os frutos estão maduros, e com ocorrência de altas temperaturas. 


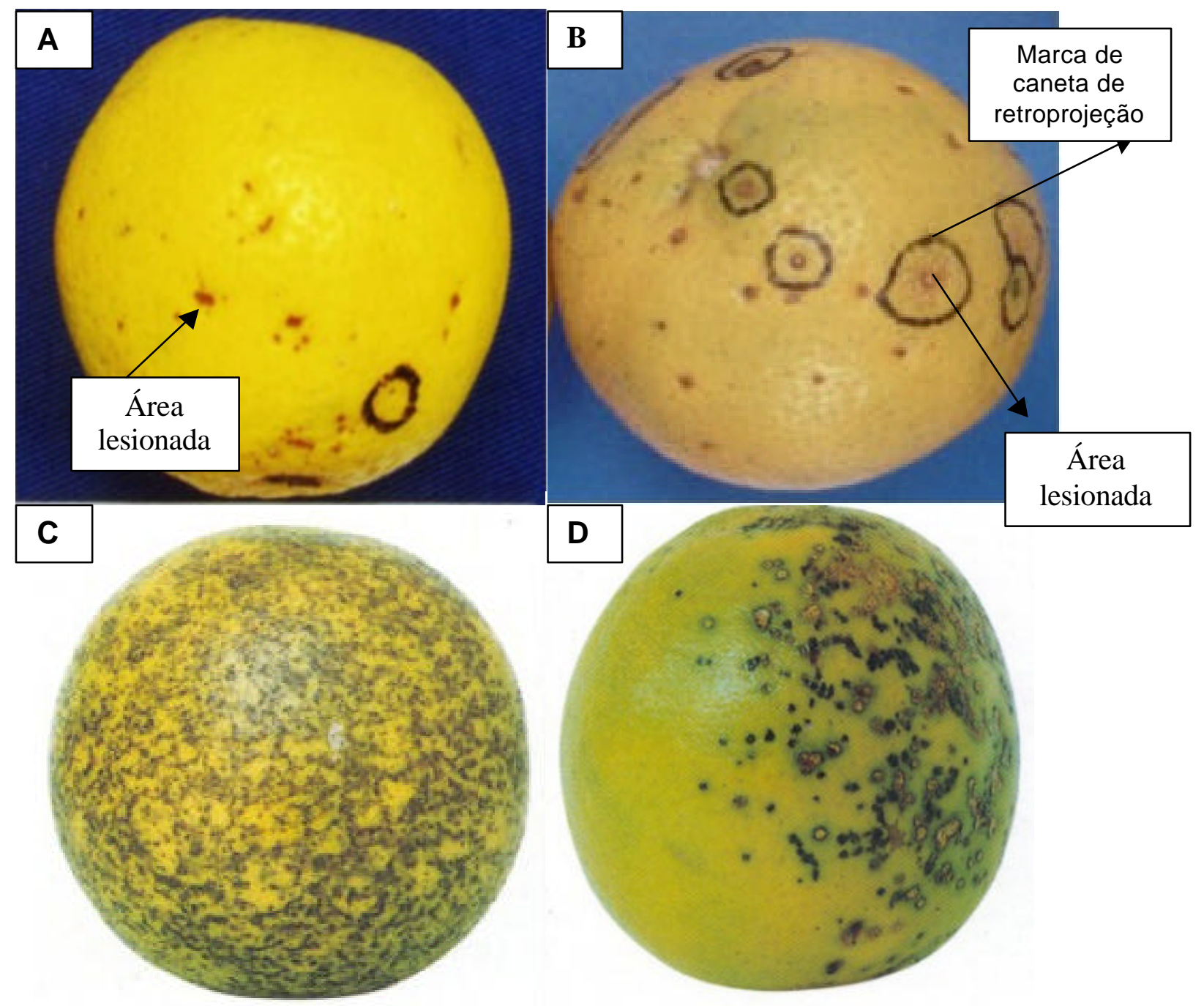

Figura 1 - Sintomas mais comuns da mancha preta dos citros (MPC), observados nos frutos em condições de campo. Mancha sardenta (A), Mancha dura ou preta (B), Falsa melanose (C) e Mancha virulenta (D). Fotos 1C e 1D obtidas de Fundecitrus (2000). 
A mancha preta dos citros pode originar-se de ascósporos e de picnidiósporos, sendo que nas epidemias, a importância dos ascósporos é bem maior. Os picnidiósporos podem ocorrer em lesões de frutos, em ramos finos e secos, e em folhas caídas no solo. Ocasionalmente, também nos pedúnculos e em folhas presas na árvore. Porém, a maior parte dos picnidiósporos é produzida sobre folhas de citros caídas no chão do pomar e, se presente, em frutos maduros infectados.

Os picnidiósporos não apresentam um mecanismo especial de liberação para a atmosfera, e aqueles presentes em folhas mortas sobre o chão podem atingir frutas suscetíveis apenas por respingos de gotas de chuva. Picnidiósporos se constituem em uma fonte de inóculo quando frutas temporãs ou frutos caídos tardiamente, com lesões, permanecem nas árvores depois do florescimento ou da formação dos primeiros frutos (Kotzé, 1981, 1996).

Os picnídios de $P$. citricarpa podem, ocasionalmente, ser encontrados em lesões de folhas verdes, ainda presentes na árvore, e em ramos secos. Sobre folhas caídas, o picnídio normalmente amadurece e libera seus esporos gelatinosos muitas semanas antes do peritécio amadurecer sobre as mesmas folhas.

A correlação entre liberação de ascósporos e início da infecção indica que o picnídio sobre folhas caídas não desempenha papel significativo como fonte de inóculo primário (Mconie, 1964).

Os ascósporos de G. citricarpa são produzidos sobre folhas caídas no chão do pomar e representam a principal fonte de inóculo depois que a doença atingiu o estágio epidêmico. Ascósporos nunca ocorrem em lesões de frutos. Estes se desenvolvem dentro de 50 a 180 dias sobre as folhas de citros caídas das árvores durante o ano. Os ascósporos maduros podem ocorrer em qualquer período do ano em um pomar de citros, mas a sua presença e abundância dependem da freqüência de umidade (chuva, irrigação, etc.) e seca, bem como das temperaturas predominantes (Kotzé, 1981). 
Ainda de acordo como o mesmo autor, o período crítico de suscetibilidade dos frutos para a mancha preta ocorre desde a fase de chumbinho até cerca de seis meses após a queda das pétalas, o que corresponde, no Estado de São Paulo, ao período compreendido entre setembro a março, dependendo das variedades e condições climáticas predominantes (Góes, 1998; Góes et al., 1990).

\subsubsection{Medidas de controle}

Dentre as medidas de controle estão o uso de mudas sadias, catação de frutas temporãs infectadas, controle de plantas daninhas nas linhas de plantio com herbicidas pós-emergentes antes do início da florada, irrigação no inverno, prevenindo a queda excessiva de folhas, uso de quebra-ventos, nutrição adequada da planta e boas condições de sanidade, desinfecção de veículos, materiais de colheita e equipamentos, e eliminação de restos de material vegetal. Associado a estes cuidados, inclui-se também o uso de fungicidas sistêmicos, a combinação de um fungicida protetor com um óleo vegetal, ou o uso de fungicida protetor isoladamente (Calavan, 1960; Góes et al., 1990; Kotzé,1981, 1996; Prates \& Nogueira, 1996). Para o caso dos fungicidas protetores, podem ser empregados os cúpricos ou os carbamatos, especialmente o mancozeb (Manzate ou Dithane). Dentre os fungicidas sistêmicos, o benomyl tem se mostrado como o mais eficiente, mas deve ser empregado com critério devido ao risco de resistência do fungo, como verificado nas condições da África do Sul (Herbert \& Grench,1985) e Brasil (Ghini \& Kimati,2000).

\subsection{Infecções latentes e quiescentes em doenças de pós-colheita}

Verhoeff (1974) definiu infecções latentes, dormentes ou quiescentes, como sendo condições nas quais o patógeno passa longos períodos de "hibernação" no tecido da planta hospedeira, restrito ao local de 
penetração, até que certos fatores fisiológicos impostos pelo tecido hospedeiro (ainda não totalmente elucidados), quebrem este período de hibernação e o patógeno torna-se ativo e os sintomas tornam-se visíveis a olho nu.

Mais recentemente, Agrios (1997) definiu infecção latente como o estádio em que um hospedeiro é infectado com um patógeno, mas não apresenta sintomas de doença, e persiste até que sinais ou sintomas estão prontos a aparecer por condições nutricionais ou pelo estádio de maturidade do hospedeiro ou patógeno. Sinclair (1991) definiu a infecção latente como um tipo de tolerância ou resistência a certos patógenos, onde o parasita encontra ambiente interno impróprio para crescimento e multiplicação, e resulta de um processo de coevolução entre plantas e patógenos. Tal coevolução permitiria aumento de resistência e adaptabilidade genética ao hospedeiro, onde a alta susceptibilidade individual de plantas e a alta virulência dos patógenos seriam eliminadas no início do processo evolutivo (Blanco, 1999).

Com relação as infecções quiescentes, no contexto de póscolheita, estas envolvem a inibição do desenvolvimento do patógeno por condições impostas pelo hospedeiro, até que algum estádio de maturação tenha se completado (Swinborne, 1983).

Segundo Rodriguez \& Redman (1997), fungos endofíticos não induzem o surgimento de sintomas de doença, mas mantêm mecanismos bioquímicos e genéticos requeridos para infecção e colonização de plantas hospedeiras, como em fungos fitopagênicos. De acordo com estes autores, há quatro classes de fungos endofíticos com base no comportamento dos mesmos no tecido vegetal: 1) fungos que crescem ativamente dentro do tecido hospedeiro, resultando em extensa colonização; 2) fungos que crescem ativamente no interior do hospedeiro, mas apenas colonizam áreas limitadas adjacentes ao ponto de infecção; 3) fungos que crescem muito pouco dentro do hospedeiro, em função de respostas deste, ficando quiescente até a senescência do hospedeiro; 4) fungos que crescem muito pouco no interior do tecido hospedeiro, mas permanecem metabolicamente ativos. A principal 
diferença entre estas classes é que o fungo que coloniza extensivamente o hospedeiro deve evitar ou burlar o sistema defensivo da planta (Azevedo, 1998).

Nesta revisão serão abordados exemplos de infecções quiescentes de fungos fitopatogênicos sob o contexto da pós-colheita, entretanto diversos grupos de bactérias são capazes de formar infecções latentes em inúmeros hospedeiros (Hayward, 1974).

\subsubsection{A quiescência durante a germinação do esporo e alongamento de hifas do patógeno}

A germinação de conídios e a formação de apressórios por Colletotrichum piperatum podem ocorrer apenas na superfície de pimentões maduros (Grover, 1971). Entretanto, isto não é uma regra geral, visto que os esporos de alguns patógenos tais como Colletotrichum musae (Prusky, 1996) podem germinar na superfície de frutos imaturos e maduros. Hifas de Botrytis allii podem penetrar em folhas jovens de cebola (Allium cepa L.), no entanto desenvolvem-se apenas em folhas mais velhas (Prusky, 1996). Similarmente, hifas de Dothiorella dominicana podem colonizar inflorescências de mangueiras, desenvolver-se endofiticamente no pedicelo do fruto e permanecer quiescentes até a maturação do fruto (Johnson et al., 1991). Em muitos casos, o patógeno coloniza as flores e permance inativo até a abscisão das pétalas, como em Diploidia natalensis em citros (Nadell, 1944 citado em Prusky, 1996). Diversos casos de quiescência para certos fungos fitopatogênicos já foram descritos na literatura desde 1935 (Tabela 1). 
Tabela 1. Exemplos de infecções quiescentes em frutos e o estádio de desenvolvimento do patógeno em que a infecção foi constatada.

\begin{tabular}{llc}
\hline Cultura & \multicolumn{1}{c}{ Patógeno } & $\begin{array}{c}\text { Desenvolvimento } \\
\text { do patógeno }\end{array}$ \\
\hline Abacate & Colletotrichum gloesporioides & Apressório \\
Abacate & Botryosphaeria ribis & Penetração \\
Banana & Colletotrichum musae & Apressório/Colonização \\
Citros & Colletotrichum gloesporioides & Apressório \\
Citros & Guignardia citricarpa & Colonização \\
Damasco & Monilinia fructicola & Pré-germinação \\
Framboesa & Botrytis cinera & Colonização \\
Maça & Gloeosporium perennans & Apressório \\
Maça & Diaporthe perniciosa & Colonização \\
Maça & Nectria galligena & Colonização \\
Manga & Colletotrichum gloesporioides & Colonização \\
Mamão & Colletotrichum gloesporioides & Colonização \\
Morango & Botrytis cinera & Colonização \\
Pimentão & Colletotrichum capsici & Colonização \\
Pimentão & Glomerela cingulata & Apressório \\
Tomate & Colletrotrichum phomoides & Apressório/Colonização \\
\hline
\end{tabular}

Fonte: Swinburne (1983).

\subsubsection{Quiescência durante a formação do apressório}

Swinburne (1976) relatou que a formação de apressório durante o ataque de $C$. musae em banana é regulado e estimulado pela presença de ácido antranílico. Este ácido está presente na casca da banana na forma de gotículas e é rapidamente transformado pelos conídios para uma forma ativa de ácido 2,3 dihidroxibenzóico (Harper \& Swinburne, 1979), o qual tem propriedades de formar quelatos e reduzir o nível de ferro ligado aos esporos. Segundo Harper et al. (1980), o ferro está associado a um sítio inibidor da germinação dos esporos de C. musae. Muitos agentes quelantes de ferro já foram citados na literatura como estimulantes da germinação de esporos e formação de apressório, o que pode ser uma explicação para o estímulo da germinação de conídios de $C$. musae na presença de sideróforos produzidos 
por bactérias na superfície de frutos de banana (McCraken \& Swinburne, 1979, 1980).

Esporos de Colletotrichum sp. podem germinar em superfícies altamente hidrofóbicas, o que sugere que a cera na superfície de frutos pode atuar como um sinal estimulatório para a interação fruto-patógeno (Podilia et al., 1993). Entretanto, este tipo de sinal é específico para cada tipo de patossistema (Kolattukudy et al., 1995). Deste modo, para Prusky (1996), os lipídios que compõem a cutícula da superfície das plantas, podem conter indutores ou inibidores para a germinação de esporos e formação de apressório e o balanço entre estes pode ser responsável pela ativação do patógeno, fazendo com que o mesmo saia do estado de quiescência para iniciar o parasitismo na planta hospedeira.

\subsubsection{Quiescência do apressório, formação da hifa de germinação e hifa subcuticular}

A possibilidade que o estádio quiescente envolva estruturas tais como apressório, formação da hifa de germinação e hifa subcuticular já foi comprovada experimentalmente em diversos patossistemas, como banana e $C$. musae, abacate, uva e C. gloeosporioides (Prusky, 1996).

Em bananas não maduras foi sugerido que a hifa subcuticular de C. musae seria a estrutura quiescente do patógeno (Sitterly \& Shay, 1960). Entretanto, Muirhead (1981) concluiu que o apressório era a estrutura quiescente de $C$. musae. Da mesma maneira, Brown $(1975,1977)$ concluiu que também na interação $C$. gloeosporioides e tangerina o apressório e não a hifa subcuticular era a estrutura quiescente.

Para C. gloeosporioides em abacate, o patógeno permanece quiescente como apressório na superfície do fruto não maduro (Binyamini \& Schiffmann-Nadel, 1972). Entretanto, mais recentemente Prusky et al. (1994) sugeriram, baseados em dados de microscopia eletrônica, que em abacate, $C$. 
gloeosporioides germina em frutos não maduros e produz hifas que penetram a cutícula e migram até as células epidérmicas dentro de 72 horas após a inoculação, mas não se desenvolvem até a maturação dos frutos. Para a interação entre frutos de uva e morango e C. gloeosporioides, também foi confirmado que o apressório é a estrutura quiescente (Hartung et al., 1981).

\subsubsection{Mecanismos da quiescência}

\subsubsection{Fatores que afetam a quiescência de esporos germinados e não germinados}

Em frutos de citros infectados por Penicillium digitatum foi constatado que elementos voláteis liberados por ferimentos, tais como $\mathrm{CO}_{2}$, etanol, limoneno e acetaldeído, além de açúcares e ácidos orgânicos (Eckert \& Ratnayake, 1994), foram responsáveis pelo incremento na germinação dos conídios. Pandey et al. (1994) relataram que o crescimento de C. gloeosporioides e Pestalotia psidii em goiaba foi inibido por extratos orgânicos e compostos voláteis de fungos dominantes, provenientes do filoplano do fruto. Para Prusky (1996), substâncias reguladoras da germinação de esporos em infecções quiescentes podem ser provenientes do próprio patógeno. Aliás, a auto-inibição de conídios é um fenômeno em várias formas de $C$. gloeosporioides. Auto-inibidores já foram identificados em C. gloeosporioides f.sp. jussiaea e C. graminicola (Tsurushima et al., 1995). Por outro lado, barreiras físicas também podem afetar a formação da hifa de penetração em infecções quiescentes, como foi comprovado na interação entre damasco e Monilinia fructicola, em que a morte celular na área de penetração induziu uma rápida suberização da parede celular em células circunvizinhas e o acúmulo de compostos fenólicos (Wade \& Cruickshank, 1992). 
Estes e outros resultados confirmam que fatores específicos (de origem do patógeno) ou de origem exógena (do hospedeiro) podem inibir ou estimular a germinação de esporos em infecções quiescentes (Prusky, 1996).

\subsubsection{Quiescência na formação de apressório}

Fatores constitutivos e exógenos podem afetar a formação do apressório quiescente (Muirhead, 1981). A dormência constitutiva pode ser afetada por inúmeros fatores que podem induzir ou inibir o desenvolvimento do patógeno (Prusky, 1996). Em contrapartida, a dormência exógena é mais provavelmente dependente da escassez de um ou mais fatores requeridos para a germinação ou da presença de inibidores de germinação (Prusky, 1996). Inibidores da germinação de apressório em infecções quiescentes podem ser compostos voláteis ou não voláteis originários do hospedeiro ou de microrganismos epifíticos (Korsten et al., 1995). Swinburne (1978) reportou que compostos antifúngicos de origem do hospedeiro (extratos da casca de frutos verdes de banana) inibiram a formação do apressório quiescente em C. musae. Muirhead (1981), em experimento semelhante, falhou na tentativa da germinação de apressório quiescente de $C$. musae usando extratos da casca de frutos maduros de banana, sugerindo que a dormência em apressórios quiescentes não pode ser quebrada naturalmente pela adição de nutrientes aplicados externamente.

Em 1994, Flaishman \& Kolattukudy propuseram que o etileno seria responsável pela formação do apressório quiescente, entretanto esta conclusão não é válida para frutos climatéricos como o abacate, mas apenas para frutos não climatéricos como a laranja (Prusky, 1996). 


\title{
2.2.4.3 Quiescência durante a penetração das hifas e colonização do hospedeiro
}

\begin{abstract}
Verhoeff (1974) e Swinburne (1983) postularam que alterações fisiológicas significativas ocorrem no hospedeiro e no patógeno durante o processo de maturação de frutos climatéricos e não climatéricos e que estimulam o estabelecimento de infecções quiescentes. Diversos mecanismos de resistência foram propostos (Swinburne, 1983) e agrupados em quatro hipóteses: (a) efeitos do hospedeiro e requerimentos nutricionais do patógeno, (b) compostos antifúngicos pré-formados, (c) compostos antifúngicos induzíveis e (d) ativação de fatores de patogenicidade.
\end{abstract}

- $\quad$ Efeitos do hospedeiro e requerimentos nutricionais do patógeno

Diversos autores, dentre os quais Simmonds (1941), citado em Prusky (1996) e Verhoeff (1974), propuseram que a ativação do patógeno em infecções quiescentes é iniciada a partir da disponibilidade de nutrientes (principalmente carboidratos, como a sacarose) no tecido da planta hospedeira. Cruickshank \& Wade (1992) sugeriram que certos compostos voláteis (tais como etanol e acetaldeídeo), produzidos durante a maturação de frutos de damasco, podem transformar o micélio inativo (quiescente) em ativo. $O$ etileno aplicado externamente em bananeira, teve efeito positivo na ativação do micélio quiescente de Diploidia natalensis em ponteiros infectados, induzindo aumentos significativos nas atividades de duas enzimas envolvidas na abscisão do fruto, a exo-poligalacturonase e a celulase, predispondo a penetração deste fungo e acarretando podridões nos ponteiros (Brown \& Burns, 1995). Ainda segundo os mesmos autores, laranjas não produzem quantidades significativas de etileno durante a colheita, portanto provavelmente outros fatores devem estar envolvidos, como a senescência dos tecidos infectados. 


\section{- $\quad$ Compostos antifúngicos pré-formados}

Segundo VanEtten et al. (1994) é difícil conduzir experimentos que possam elucidar o papel de compostos pré-formados (fitoanticipinas) na resistência a doenças, visto que em muitos casos mudanças nas concentrações de compostos inibitórios não coincidem com as alterações ocorridas durante a susceptibilidade (Schulz, 1978) e experimentos de imersão de frutos em substâncias antifúngicas na maioria dos casos estudados, não demonstraram aumentos na resistência dos mesmos em podridões pós-colheita (Prusky, 1996; Sitterly \& Shay, 1960).

\section{- $\quad$ Compostos antifúngicos induzíveis (fitoalexinas)}

A indução de fitoalexinas em vários tipos de infecções quiescentes já foi citada inúmeras vezes em diversos trabalhos na literatura. Dentre estas temos o capsicanol, 1-deoxicapsidiol e endesmadienol, associados a infecções quiescentes em frutos de pimentão (Capsicum annuum) inoculados com Glomerella cingulata (Adikaram et al., 1982). Em citros, um composto identificado como 3-[4-hidroxi-3-(metil-2-butenil) fenil]-2-(e)-propenal, com características de fitoalexina foi encontrado no exorcarpo injuriado (Stange et al., 1993 citado em Prusky, 1996). Em cenoura, poliacetelenos, falcarindiol e falcarinol foram identificados como prováveis fatores de resistência a Botrytis cinerea (Harding \& Heale, 1980).

\section{- $\quad$ Ativação de fatores de patogenicidade}

De acordo com Agrios (1997), a maioria dos patógenos, com exceção dos vírus e viróides, podem produzir uma variedade de enzimas, normalmente extracelulares, que atuam na degradação dos polímeros estruturais componentes da parede celular (ex. pectinases, celulases, hemicelulases, ligninases e pectato liases). Essas enzimas mostram-se induzíveis, estáveis e o contato entre estas enzimas e a parede celular pode ser visto como uma das primeiras interações moleculares. Inúmeros trabalhos já 
demonstraram que muitas destas enzimas podem atuar como fatores específicos de patogenicidade e devem ativar apressórios ou esporos em estádio de dormência em infecções quiescentes (Prusky, 1996).

A importância da pectato liase (PL), como fator de patogenicidade durante a ativação de infecções quiescentes, foi comprovada recentemente em abacates infectados com C. gloeosporioides, demonstrando que quando os níveis de compostos fúngicos pré-formados diminuía à medida que o fruto amadurecia, a produção de PL aumentava (Wattad et al., 1994).

Conclusivamente, a ativação de infecções quiescentes não deve ser resultante apenas da redução de barreiras físicas induzíveis ou préformadas, mas também da produção de sinais específicos do hospedeiro (fatores de susceptibilidade), tais como o etileno, que ativariam genes silenciosos em apressórios ou esporos quiescentes, estimulando a indução dos fatores de patogenicidade (patógeno), permitindo o desenvolvimento das doenças de pós-colheitas (Prusky, 1996).

\subsection{Indução de resistência em plantas contra patógenos}

O fenômeno da resistência induzida tornou-se conhecido apenas no início do século passado, tendo como marco inicial, o trabalho desenvolvido por Chester em 1933 (Moraes, 1998). A partir desse trabalho, muitos outros foram realizados na busca de produtos de defesa com função semelhante àde anticorpos animais em plantas (Lucas, 1999), entretanto, todos fracassaram. Um segundo marco foi a descoberta das fitoalexinas, nos anos 40 , as quais foram mais amplamente estudadas na década de 70 (Pascholati, 1998).

O potencial para o uso de indutores de resistência no controle de doenças não chamou a atenção apenas da comunidade acadêmica, mas também da área comercial. Atualmente, existem alguns produtos que exploram os mecanismos de resistência da planta em uso no mercado internacional, 
dentre os quais temos o Oryzamate $^{\circledR}$ (Watanabe et al., 1979), Elexa ${ }^{\circledR}$ (SafeScience, 2001), Bion ${ }^{\circledR}$ (Görlach et al., 1996), Milsana ${ }^{\circledR}$ (Daayf et al., 2000), Messenger ${ }^{\circledR}$ (Eden BioScience, 2001), Phytogard ${ }^{\circledR}$ (Pajot et al., 2000), Oxycom $^{\mathrm{TM}}$ (Yang et al., 2001). Dentre estes, apenas o Oryzamate ${ }^{\circledR}$, Bion $^{\circledR}$, Messenger $^{\circledR}$, Oxycom $^{\mathrm{TM}}$ e o Elexa ${ }^{\circledR}$ têm registro como indutores de resistência de plantas (Labanca, 2002). O Oryzamate ${ }^{\circledR}$ (probenazole) é um produto para proteção do arroz contra a brusone e já conta com 20 anos de mercado no Japão, sem que haja um único relato do surgimento de resistência em populações de Pyricularia oryzae (Ishii et al., 1999; Yoshioka et al., 2001). O Bion ${ }^{\circledR}$ (acibenzolar S-metil, ou BTH) foi lançado em 1996 na Alemanha e atualmente já tem registro na Suíça, países da Europa Oriental e África do Sul, França, no Reino Unido e EUA (Hammershmidt, 1999) e é o único com registro

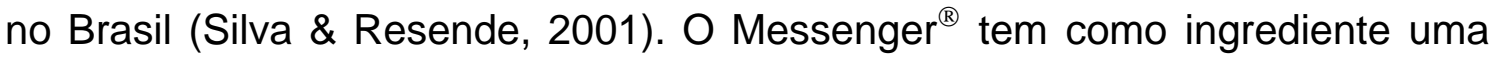
proteína produzida por Erwinia amylovora, a harpina (Eden BioScience, 2001). Segundo Labanca (2002), o Elexa ${ }^{\circledR}$ tem como ingrediente ativo a quitosana (quitina deacetilada), extraída de exoesqueletos de crustáceos. Por sua vez, o Oxycom $^{\mathrm{TM}}$ é uma combinação de uma mistura de nutrientes e ácido paracético (Yang et al. (2001). Ainda segundo os mesmos autores, o produto é capaz de aumentar a atividade de enzimas ligadas à RSA, como por exemplo, a fenilalanina amônia-liase (FAL) e proteger plantas contra fitopatógenos.

Embora a indução de resistência tenha grande potencial de uso agrícola, não deve ser encarada como uma solução redentora para todos os problemas fitossanitários. Várias etapas envolvidas na ativação de muitos mecanismos de indução de resistência, são ainda um mistério. Há quem levante a possibilidade do uso de um indutor de resistência para dado patógeno ter efeito de indutor de suscetibilidade a pragas e animais herbívoros (Bostock, 1999). 


\subsubsection{Princípios da indução de resistência}

A indução de resistência ocorre naturalmente como resultado de uma infecção limitada do patógeno, particularmente quando a planta desenvolve uma reação de hipersensibilidade (Van Loon et al., 1998). Esta pode ser ativada por inúmeros agentes denominados indutores e, geralmente, esta indução é sistêmica (Hammerschmidt, 1999). Segundo Hammerschmidt (1999) devido a esta característica, a indução de resistência é geralmente definida como resistência sistêmica adquirida (RSA).

A primeira etapa, das muitas que compõem a resposta da planta a um indutor, é o reconhecimento do indutor pela planta. $O$ indutor pode ser um produto químico, como o ácido salicílico, um patógeno avirulento, parte de um patógeno, como uma glicoproteína (Costet et al., 1999), um carboidrato estrutural (Andreu et al., 1998), um organismo não patogênico, como as bactérias promotoras de crescimento (Mauch-Mani \& Metraux, 1998), luz ultravioleta (Stevens et al., 1999) ou um estresse de natureza biótica (Kessmann et al., 1994) ou abiótica (Moran \& Cipollini, 1999). Após o contato com o indutor, seja na parte aérea (Shulaev et al., 1997) ou nas raízes (Knoester et al., 1999), ocorre o reconhecimento do indutor pela planta. Em resposta ao reconhecimento, as plantas sofrem alterações que culminam com a geração de um sinal primário. Esse sinal tem características de um fitohormônio, sendo produzido em pequenas quantidades e translocado do local de síntese para o local de atuação (Hammerschmidt \& Kuc, 1995).

O sinal primário produzido pode tanto ser translocado, como produzir outros sinais que serão translocados. Uma outra possibilidade é que o sinal primário leve à produção de substâncias, como as proteínas relacionadas àpatogênese (proteínas-RP), que atuando sobre a parede celular de um fungo podem liberar substâncias que serão translocadas e servirão como sinalizadores em outra parte da planta (Hammerschmidt, 1999). Os sinais 
gerados levam àativação de determinados genes que por sua vez estimulam a produção de substâncias de defesa, como as fitoalexinas, as proteínas-RP (Sticher et al., 1997) e defensinas (Mauch-Mani \& Metraux, 1998; Segura et al., 1998), ou aumentam a atividade de enzimas, como as peroxidases (Moran \& Cippollini, 1999) e a fenilalanina amonia-liase (Stevens et al., 1999) que têm importante papel na síntese de compostos de defesa.

Uma das mais efetivas respostas que a planta tem frente a interações incompatíveis planta-patógeno é a reação de hipersensibilidade $(R H)$ (Van Loon \& Van Strien, 1999). Muitos autores afirmam que em plantas induzidas à resistência, esta só ser manifestará se houver reação de hipersensibilidade ou algum tipo de necrose (Costet et al., 1999; Hammerschmidt, 1999). A RH é associada com a formação de barreiras estruturais e bioquímicas que impedem ou retardam tanto o avanço do patógeno, que já penetrou na célula, como novas penetrações. A ocorrência de morte celular está ligada a um aumento da atividade respiratória, àalteração de fluxo de íons através da membrana plasmática, àgeração de espécies ativas de oxigênio, às mudanças no estado de fosforilação de proteínas reguladoras e à ativação da transcrição de sistemas de defesa da planta (acúmulo local de fitoalexinas, fenóis e proteínas-RP e enrijecimento da parede celular, devido ao acúmulo de lignina, suberina ou calose).

A indução de resistência já foi demonstrada, até o presente momento, em inúmeras espécies de plantas, distribuídas entre diversas famílias botânicas, tanto em dicotiledôneas como em monocotiledôneas (Lucas, 1999). A resistência induzida também se mostrou efetiva contra fungos, vírus, bactérias, insetos, ácaros e nematóides (Lucas, 1999; Ogallo \& McClure, 1996; Sticher et al., 1997). A seleção natural e a co-evolução levaram as plantas a selecionarem uma série de mecanismos de defesa. É importante observar que as defesas identificadas em plantas resistentes estão também presentes em plantas suscetíveis. Provavelmente, a diferença entre resistência e 
suscetibilidade pode ser o resultado de uma variação de tempo, autonomia celular ou intensidade das respostas de defesa das plantas (Moraes, 1998).

As plantas defendem-se dos fitopatógenos passiva ou ativamente. Deste modo, para facilitar o estudo, os mecanismos de resistência são divididos em duas categorias: pré e pós-formados. Em ambos, pode ocorrer a divisão em estruturais e bioquímicos. Dentre os pré-formados estruturais, estão a presença de cutícula, tricomas, tipo de estômatos, fibras e forma dos vasos condutores. Entre os bioquímicos, estão os fenóis, alcalóides, lactonas insaturadas, glicosídeos fenólicos, fototoxinas e inibidores protéicos. Nos pósformados, também chamados induzíveis, podemos encontrar mecanismos estruturais, papilas, halos, lignificação, formação de camadas de cortiça, calose, silício, tiloses em vasos, etc; e os bioquímicos, tais como produção de fitoalexinas, proteínas-RP, glicoproteínas ricas em hidroxiprolina, inibidores de proteases, peroxidases, entre outros (Pascholati \& Leite, 1994).

\subsubsection{Alguns mecanismos de defesa induzidos exibidos pela planta em resposta ao ataque de patógenos}

\subsubsection{Proteínas vegetais relacionadas à patogênese (proteínas-RP)}

Em muitas espécies de plantas, a resposta à infecção por bactérias, vírus e fungos patogênicos ou a vários estresses abióticos é acompanhada pela síntese de uma variedade de proteínas, muitas delas chamadas proteínas-RP ou "proteínas relacionadas àpatogênese" (Van Loon \& Van Kammen, 1970; Niderman et al., 1995). Essas proteínas foram primeiramente descritas por Van Loon \& Van Kammen (1970), em folhas de fumo, após a infecção pelo vírus do mosaico (tobacco mosaic virus -TMV). As proteínas RP não eram detectadas em folhas sadias, mas tinham sua atividade induzida em folhas inoculadas com o vírus (Liu et al., 1995). Desde então têm sido detectadas em varias espécies vegetais, incluindo mono e dicotiledôneas 
(Albrecht et al., 1994; Daugrois et al., 1990; Liu et al., 1995; Ji \& Kuc, 1996; Mohr et al., 1998; Sela-Buurlage et al., 1993;Yi \& Hwang, 1996; Vogeli et al., 1998). Baseando-se primeiramente em propriedades serológicas e depois em dados de sequenciamento, as proteínas-RP do fumo foram classificadas em 5 grupos principais, denominados RP1, RP2, RP3, RP4, RP5. Posteriormente, foram descritas 14 famílias (Van Loon \& Van Strien 1999).

\subsubsection{Fitoalexinas}

Fitoalexinas são compostos de baixa massa molecular provenientes do metabolismo secundário de planta, sintetizados em resposta a estresses físicos, químicos ou biológicos. São capazes de impedir ou reduzir a atividade de agentes patogênicos, sendo a taxa de acúmulo dependente dos genótipos do hospedeiro e/ou patógeno (Purkayastha, 1995). O envolvimento das fitoalexinas nas respostas de resistência das plantas contra patógenos vem sendo estudado por mais de quatro décadas (Daniel \& Purkayastha, 1995). Para Ebel (1986), as fitoalexinas englobam diversas classes de produtos naturais, tendo sido caracterizadas mais de 300 fitoalexinas incluídas em diferentes classes químicas, como benzofurano, cumarina, dihidrofenantreno, diterpeno, flavonóide, furanoacetileno, isocumarina, isoflavonóide, pterocarpano, sesquiterpeno, stilbeno e triterpeno, em mais de 20 famílias de vegetais superiores (Smith, 1996).

As fitoalexinas agem sobre fungos, bactérias, vírus, células vegetais e animais, sendo ativas em concentrações da ordem de $10^{-5}$ a $10^{-4} \mathrm{M}$ (Ebel, 1986; Smith, 1982). De modo geral, o resultado da ação das fitoalexinas sobre os fungos inclui granulação citoplasmática, desorganização dos conteúdos celulares, ruptura da membrana plasmática e inibição de enzimas. Esses efeitos citológicos refletem-se na inibição da germinação e elongação do tubo germinativo e redução ou inibição do crescimento micelial (Hipskind et al., 1990; Lo et al., 1996; Smith, 1996). 
Em sorgo, ocorre a produção de um complexo de compostos fenólicos, dentre os quais foram identificadas cinco fitoalexinas do tipo deoxiantocianidinas: luteolinidina, 5-metoxiluteolinidina, apigeninidina e éster do ácido cafeico de arabinisol 5-O-apigeninidina e 7-metoxiapigeninidina (Hipskind et al., 1990; Lo et al., 1996; Nicholson et al., 1987). Em cana-de-açúcar, foi encontrada uma deoxiantocianidina, luteolinidina, que atua como inibidora de crescimento fúngico, embora seu papel na resistência não tenha sido estudado (Godshall \& Lonergan, 1987). A indução para produção dessas fitoalexinas pode ocorrer em resposta à penetração fúngica (Snyder et al., 1991), ao tratamento com elicitores bióticos (Wulff, 1997; Yamaoka et al., 1990), abióticos (Freitas et al., 1993) ou ferimentos (Lopez \& Pascholati, 1992).

\subsubsection{Alguns sinais envolvidos na indução de resistência sistêmica a patógenos em plantas}

Para que um composto seja considerado um sinalizador, é necessário que este seja sintetizado pela planta, aumente significativamente após o ataque de patógeno ou após o tratamento com o indutor, seja móvel pelo floema da planta, induza a síntese de substâncias de defesa, como as proteínas-RP, peroxidases ou fitoalexinas e aumente a resistência a patógenos (Bostock, 1999; Moraes, 1998). A busca de um sinalizador primário nos sistemas de indução ou ativação de resistência não apresentou, até o momento, conclusões definitivas. Vários compostos são tidos como importantes na sinalização, mas nenhum deles pode ser apontado, com certeza, como o sinal primário. Segundo Hammerschmidt \& Kuc (1995), para a síntese de um sinalizador orgânico, a célula necessitaria de um sinal que ativasse determinados genes, sendo esse o sinal primário. Por outro lado, os mesmos autores não descartam a hipótese desse composto orgânico existir, mas estar compartimentalizado, sendo liberado somente no momento de uma injúria. 


\subsubsection{1 Ácido salicílico e seus derivados}

O ácido salicílico (AS) é provavelmente sintetizado na via dos fenilpropanóides, tendo o ácido benzóico como precursor. Na síntese através desta via, é importante a participação da FAL (Hammerschmidt \& Kuc, 1995). Logo após a síntese, o AS é convertido na forma conjugada com carboidratos. Sendo que a conjugação pode ser um importante mecanismo pelo qual a concentração de AS é regulada na planta (Moraes, 1998).

O AS, quando aplicado de forma exógena, é capaz de induzir aumento da síntese do próprio AS, assim como de proteínas-RP e de proteger as plantas contra ataque de patógenos (Spletzer \& Enyedi, 1999). Plantas tratadas com indutores sejam eles bióticos ou abióticos, também apresentam a mesma gama de respostas (Görlach et al., 1996; Sticher et al., 1997).

Em estudos recentes com pepino e fumo, foi demonstrado que 0 AS é móvel na planta durante o fenômeno da RSA e que sua concentração no floema, no caso de pepino, aumenta com o aumento da atividade da FAL no pecíolo (Mauch-Mani \& Metraux; 1998).

O AS pode gerar em várias plantas a produção de um composto volátil, o metil-salicilato (MeSA). O MeSA, por sua vez, pode induzir plantas a sintetizar o AS. Plantas de fumo infectadas por TMV são capazes de produzir o MeSA, que age como um indutor de resistência volátil. A produção de AS a partir do MeSA produzido pela planta atacada induz a produção de proteínasRP e a ativação de genes de resistência (Shulaev et al., 1997), podendo tornar plantas sadias resistentes ao ataque de patógenos.

O modo pelo o qual o AS atua ativando os genes de resistência desencadeando a RSA ainda é objeto de especulação (Hammerschmidt, 1999; Lucas, 1999; Mauch-Mani \& Metraux; 1998). Recentemente, o uso de plantas transgênicas, especificamente transformadas para a superexpressão de certos 
genes nelas introduzidos, tem sido instrumento muito útil para esse tipo de estudo (Hammerschmidt, 1999).

\subsubsection{Jasmonatos e seus derivados}

O ácido jasmônico e seus derivados encontram-se largamente distribuídos nos tecidos vegetais (Bostock, 1999). Segundo Sticher et al. (1997), os jasmonatos (JA) são produzidos em plantas após injúrias ou tratamentos com elicitores (Kozlowski et al., 1999), apresentando funções hormonais e de defesa contra fitopatógenos e insetos (Sticher et al., 1997). A ação de defesa está ligada à capacidade de induzir a síntese ou acúmulo de proteínas inativadoras de ribossomos, FAL, tionina, sintase da chalcona, proteínas ricas em hidroxiprolina, inibidores de proteinases e outros fatores como polifenoloxidases e lipoxigenases (Bostock, 1999; Kozlowski et al., 1999).

A via de sinalização na qual os JA estão envolvidos tem diferenças marcantes em relação à via de sinalização que envolve o AS. Atualmente, costuma-se diferenciar o tipo de resistência envolvido com cada via. O tipo de resistência que envolve os JA é referido como resistência sistêmica induzida (RSI) e a do AS como RSA. O papel dos JA na sinalização e mesmo na resposta de defesa da planta, é menos esclarecido do que a do AS. No entanto, o JA é proposto como um sinalizador secundário da RSI (Sticher et al., 1997). Inúmeros estudos evidenciam a importância dos JA na resposta de defesa das plantas contra fitopatógenos (Bostock, 1999; Mauch-Mani \& Metraux, 1998). 


\subsubsection{Etileno}

O etileno é um hormônio vegetal volátil de múltiplas funções fisiológicas em plantas e é produzido como conseqüência de injúria, de tratamento com elicitores e através de vários processos metabólicos. A participação do etileno na RSI ou na RSA não é clara. Por um lado, alguns estudos mostram sua necessidade para a expressão de resistência (Knoester et al., 1999). Entretanto, outros indicam que a síntese de etileno após uma infecção deve ser um sintoma e não uma causa da indução de respostas de defesa (Sticher et al., 1997). O tratamento com etefon (liberador de etileno) leva algumas plantas a expressarem proteínas-RP (Jacobs et al., 1999), indicando a possibilidade do etileno ter participação na expressão da resistência.

\subsubsection{Indutores de resistência em vegetais}

A resistência sistêmica adquirida pode ser induzida por microrganismos, preparações microbianas ou compostos químicos (Hammerschmidt \& Kuc, 1995). Para ser considerado um ativador de RSA, o indutor deve satisfazer três características: i) deve induzir resistência contra o mesmo espectro de patógenos que a RSA ativada biologicamente; ii) o composto ou seus metabólitos não deve exibir atividade antimicrobiana direta; iii) deve ocorrer indução dos mesmos mecanismos bioquímicos observados após a indução da RSA por patógenos (Ryals et al., 1996).

\subsubsection{Indutores bióticos}

Inúmeros trabalhos evidenciam o potencial da levedura $S$. cerevisiae na ativação de mecanismos de resistência e na proteção de plantas 
contra fitopatógenos (Lyon et al., 1995; Martins et al., 1986; Silva \& Pascholati, 1992; Pascholati, 1998; Roveratti, 1989). Recentemente, o grupo de pesquisas do Laboratório de Fisiologia e Bioquímica Fitopatológica do setor de Fitopatologia da Escola Superior de Agricultura Luiz de Queiróz (ESALQ), liderado pelo Prof. Pascholati, demonstrou o efeito de suspensões de células dessa levedura (linhagem de panificação), bem como do filtrado dessas suspensões na proteção de plantas de sorgo contra Colletotrichum graminicola e Exserohilum turcicum (Lopez, 1991; Piccinin, 1995), milho contra C.graminicola e E. turcicum (Silva \& Pascholati, 1992; Stangarlin \& Pascholati, 1994), maracujá contra Xanthomonas campestris pv. passifora (Piccinin, 1995) e eucalipto contra Botrytis cinerea (Piccinin, 1995). Em resultados mais recentes, evidenciaram a obtenção de elicitores glicoproteicos de $S$. cerevisiae, os quais estimulam o acúmulo de fitoalexinas em mesocótilos de sorgo (Wulff \& Pascholati, 1998, 1999; Labanca, 2002).

\subsubsection{Indutores abióticos}

Diversos compostos químicos, como ácido salicílico (AS), ácido dicloroisonicotínico (INA), silício, fosfato, 2-tiouracila, ácido poliacrílico, ácidos nucléicos e fosetil de alumínio foram identificados como potentes ativadores de resistência. Entretanto, em determinadas concentrações, podem atuar diretamente sobre o fitopatógeno, contrariando um dos critérios de um indutor de RSA (Ryals et al., 1996).

A descoberta da importância do AS na expressão da RSA veio de

uma série de experimentos realizados com plantas transgênicas que expressavam o gene nagH ( o qual converte o AS em composto não ativo, o catecol). Plantas de fumo transformadas e, portanto, incapazes de acumular AS não produziam proteínas-RP e manifestavam hipersuscetibilidade a uma série de patógenos. Essa situação podia ser revertida com a aplicação exógena de 
SA nas plantas transformadas (Bostock, 1999). Segundo Hammerschmidt \& Kuc (1995) a inibição da atividade da FAL em Arabidopsis converteu a relação Arabidopsis - P. parasitica de incompatível para compatível, provando mais uma vez a importância do AS (e via dos fenilpropanóides) na interação plantapatógeno.

Os experimentos relatados acima apontavam fortemente na direção de que o AS era o sinal primário na RSA (Hammerschmidt, 1999). No entanto, mais recentemente, foi demonstrado que o AS não poderia ser o sinal primário da RSA. Em plantas de fumo enxertadas, com porta-enxerto transformado com o gene nagH e o enxerto não, houve o acúmulo de AS no enxerto (Sticher et al., 1997). Em outros experimentos, Costet et al. (1999), usando folhas de fumo modificadas (também com o gene nagH) elicitadas com uma glicoproteína, obtiveram a síntese de algumas proteínas-RP e expressão de resistência, mostrando mais uma vez que o AS não poderia ser o sinalizador primário. Para que um composto seja considerado um sinalizador, é necessário que este seja sintetizado pela planta, aumente significativamente após o ataque de patógeno ou após o tratamento com o indutor, seja móvel pelo floema da planta, induza a síntese de substâncias de defesa, como as proteínas-RP, peroxidases ou fitoalexinas e aumente a resistência à patógenos (Bostock, 1999; Moraes, 1998).

Por sua vez em 1996, um éster S-metil do ácido benzo $(1,2,3)$ tiadiazol-7 carbotióico (conhecido por Bion, BTH ou CGA 245704) foi produzido e liberado comercialmente na Alemanha, como o primeiro ativador de defesa vegetal (Görlach et al., 1996), visando a indução de resistência sistêmica em plantas. $\mathrm{O}$ BTH mostrou-se particularmente efetivo em plantas monocotiledôneas, sendo que uma única aplicação em trigo (geralmente $60 \mathrm{~g} /$ hectare) resultava em proteção significativa das plantas por várias semanas contra Erysiphe graminis, além de suprimir a mancha de folha e ferrugem causada por Septoria sp. e Puccinia sp., respectivamente. Similarmente, uma 
única aplicação do Bion em arroz propiciava uma proteção bastante longa contra Pyricularia oryzae. O ativador vegetal também induziu resistência em plantas dicotiledôneas como fumo, pepino, tomate e feijão, porém várias aplicações foram necessárias para reduções significativas nos sintomas (Hammerschmidt \& Dann, 1997). Aparentemente, o BTH estimula as mesmas respostas de defesas observadas após o tratamento das plantas, sendo provavelmente um análogo funcional do ácido salicílico (Görlach et al., 1996). De acordo com a literatura, o Bion é um produto de baixa toxicidade (Friedrich et al., 1996), sendo que na maioria dos casos estudados não apresenta atividade antimicrobiana direta sobre o patógeno. Entretanto, Pascholati et al. (1998) relataram o efeito direto do Bion sobre Colletotrichum graminicola.

\subsubsection{Potencial da indução de resistência no controle de doenças de plantas}

A liberação do BHT representa um avanço significativo para as novas estratégias de controle de doenças vegetais. É bastante provável que a resistência induzida contra doenças através de ativadores químicos, como o $\mathrm{BHT}$ ou por outros meios, se torne um componente importante dos programas de manejo de doenças, particularmente nos casos onde os métodos atuais de controle mostram-se pouco efetivos (Hammerschmidt \& Dann, 1997; Kalix et al., 1996), bem como no controle de doenças de pós-colheita envolvendo frutas e vegetais (Prusky et al., 1994; Wilson et al., 1994). O uso de ativadores de resistência vegetal isoladamente ou associados a outras práticas agrícolas, deve ir de encontro às necessidades de uma agricultura sustentável: produtividade, qualidade e menor impacto ao meio ambiente.

Além disso, resistência induzida em plantas, pode ser utilizada como uma ferramenta para os estudos bioquímicos e fisiológicos envolvendo os mecanismos de resistência e suscetibilidade nas interações planta-patógenos (Pascholati \& Leite, 1994). 


\subsection{Compostos fenólicos}

Os compostos fenólicos vegetais podem ser didaticamente divididos em duas classes gerais: (1) aqueles que são sintetizados durante o desenvolvimento normal dos tecidos da planta (Dey \& Harborne, 1997) e (2) os que são sintetizados pelas plantas em resposta a uma injúria física, infecção (bactéria, fungo, nematóides e vírus) ou qualquer outro tipo de estresse (nutricional, hídrico, poda, etc) (Nicholson \& Hammerschmidt, 1992).

De acordo com Mace (1963), dentro dos papéis dos compostos fenólicos na planta, podemos incluir: (1) coloração do aparato polinizador da planta (cor das flores, e pétalas, auxiliando na polinização), (2) proteção contra injúria provocada pela radiação UV, (3) ação repelente contra animais herbívoros e insetos, devido a sua natureza tóxica, (4) resistência a patógenos, barreiras estruturais e bioquímicas pré e pós-formadas, e (5) liberação de compostos voláteis que podem estimular ou inibir o desenvolvimento de plantas vizinhas (alelopatia).

Ainda segundo Mace (1963), os compostos fenólicos em raízes de banana (Musa acuminata L.) ficam armazenados em células especializadas, denominadas de células de tanino, que estão distribuídas aleatoriamente no parênquima do xilema na forma de dopamina (3-hidroxitiramina). Esta descoberta foi extremamente importante, visto que permitiu inferir que fenólicos no estado livre são quase inexistentes na planta ou estão oxidados ou polimerizados nas células vegetais. Segundo Beckman (2000), a polimerização ou oxidação ocorre por intermédio de $\mathrm{H}^{+}$-ATPases e geralmente a concentração de $\mathrm{H}^{+}$no vacúolo é mais alta que no citoplasma, o que permite manter os grupos hidroxi dos compostos fenólicos em um estado não ionizado no interior dos vacúolos.

Em estudos bioquímicos e histoquímicos nos vacúolos de células de raízes de algodão (Gossypium hirsutum L.), Mace et al. (1978) e ainda Mace \& Howell (1974) mostraram a ocorrência de catequina e galocatequina. 
Deste modo, fica evidente que estes compostos apresentam uma distribuição especializada nos tecidos da planta e que uma complexa rede enzimática colabora na síntese destes compostos, que são armazenados em estado reduzido dentro dos vacúolos, como, por exemplo, os glicosídios (forma não tóxica para a planta de alguns flavonóides). Assim sendo, quando a planta é submetida a qualquer tipo de estresse biótico ou abiótico, estes compostos passam de uma forma atóxica, reduzida e compartimentalizada, para uma forma tóxica, não reduzida, ocorrendo a descompartimentalização (Beckman, 2000). Para Nicholson \& Hammerschmidt (1992) os compostos fenólicos exercem um papel fundamental nas respostas de defesa da planta e a sua distribuição relativa em tecidos especializados poderá ajudar a explicar as diversas variações estruturais e bioquímicas, pré e pós-formadas em plantas expostas ao estresse abiótico e biótico citados na literatura.

\subsubsection{Compostos fenólicos em citros}

Compostos fenólicos em citros, como em outras angiospermas em geral, são produtos do metabolismo secundário, que se acredita ser resultante da interação planta e ambiente (Afek et al., 1986; Laks \& Pruner, 1989; Snyder \& Nicholson, 1990 Zaat et al., 1987).

Como já foi mostrado anteriormente, estes compostos são derivados da fenilalanina e absorvem luz na faixa do ultravioleta (UV) (Horowitz, 1961). Em geral absorvem luz UV ao redor de $285 \mathrm{~nm}$ e dentre os principais compostos fenólicos encontrados nos citros podemos incluir flavonóides (flavononas, flavonas e flavonols), antocianinas e coumarinas (Horowitz, 1961; Zaat et al., 1987).

Dentre os compostos fenólicos encontrados, as coumarinas reconhecidamente atuam como fitoalexinas (Afek et al., 1986; Feldman \& Hanks, 1968; Nakatani et al., 1987). Inúmeras outras fitoalexinas já foram 
encontradas em citros, sendo as mais conhecidas: escoparona, umbeliferona e xantiletina (Afek et al., 1999; Afek \& Sztejnberg, 1988; Akhatar et al., 1985).

Desde longa data, os compostos fenólicos (flavononas, flavononas metoxiladas) e alguns ácidos fenólicos, presentes em citros, despertaram o interesse do homem tendo em vista diversas propriedades médicas e alimentícias (Horowitz, 1961, Widmer \& Montanari, 1994). Alguns destes compostos fenólicos exibem atividade antiviral (como a hesperidina - Kaul et al., 1985) e antimicrobiana (como o limoneno - Robbins, 1980).

Segundo Widmer \& Montanari (1994), dentre os flavonóides glicosídios cítricos mais abundamente utilizados na indústria alimentícia, temos naringina e narirutina (em pomelo), hesperidina (em laranja e tangerina) e eriocitrina (em limão e lima).

Evidências sugerem que os fenólicos cítricos, assim como os fenólicos de outros vegetais, exerçam importante papel na regulação do metabolismo vegetal. Jacobs \& Rubery (1988) reportaram a importância de alguns flavonóides glicosídios na regulação do transporte de auxinas.

A identificação destes compostos em citros, bem como em outras plantas é baseada em separações seguidas de extrações e recristralizações, via cromatografia de papel, de coluna e de camada delgada (Anis \& Aminuddin, 1981; Hattori et al., 1952; Tomas et al., 1978). Estes técnicas permitem isolar flavonas, psoralenos e coumarinas (Tatum \& Berry, 1979).

As cromatografias de coluna e de camada delgada são geralmente usados em estudos quantitativos para alguns dos compostos fenólicos em citros (Albach \& Redman, 1969; Albach et al., 1981; Mizuno et al., 1987; Tomas et al., 1978).

Estudos usando HPLC (cromatografia líquida de alta resolução) corfirmaram a existência de uns poucos novos compostos fenólicos (Widmer \& Montanari, 1994). 


\subsubsection{O papel dos compostos fenólicos na resistência de plantas às doenças}

Dentre os fenóis com atividade antibiótica encontrados em plantas, alguns são constitutivos e atuam como inibidores pré-formados associados à resistência não hospedeira (Cadena-Gomez \& Nicholson, 1987; Millar \& Higgins, 1970; Schonbeck \& Schlosser, 1976) e outros são formados em resposta ao ingresso de fitopatógenos e são considerados como parte da defesa ativa das plantas (Nicholson \& Hammerschmidt, 1992).

Em 1980, Heath inferiu que as respostas das plantas a fitopatógenos podem ser baseadas em interações hospedeiras e não hospedeiras. Em tais relações, o reconhecimento de um fitopatógeno potencial é caracterizado pelo acúmulo de compostos fenólicos no sítio de infecção, limitando a ação do patógeno resultando em uma rápida morte celular (Fernandez \& Heath, 1989).

Esta rápida morte celular inclui a formação de lignina, de papilas (Aist et al., 1988) e o acúmulo prévio de compostos fenólicos dentro da parede celular das células hospedeiras (Niemann et al., 1991a; Niemann et al., 1991b; Shiraishi et al., 1989).

Inúmeros estudos histoquímicos, com azul de toluidina $\mathrm{O}$, sugerem que compostos fenólicos de baixo peso molecular, tais como ácidos benzóicos e fenilpropanóides, são formados em resposta àinfecção cerca de 3 horas após a infecção (Bruzzese \& Hasan, 1983; Kurosaki et al., 1986; Niemann et al., 1991b).

A esterificação do ácido ferúlico na parede celular de células hospedeiras infectadas é uma resposta comum encontrada em diversos experimentos (Matern \& Kneusel, 1988).

Bell (1980) e Matern \& Kneusel (1988) propuseram que a estratégia defensiva das plantas pode apresentar dois estádios. No primeiro, envolveria o rápido acúmulo de compostos fenólicos no sítio de infecção, que 
tem como função impedir ou diminuir o crescimento do patógeno e permitir a ativação de respostas de defesas secundárias. No segundo, a ativação das respostas defensivas secundárias envolveria a síntese de compostos de defesa específicos, tais como as fitoalexinas, proteínas-RP, espécies reativas de oxigênio e outros compostos relacionados a este tipo de estresse.

Desta forma, resumidamente, a seqüência de eventos defensivos (em ordem) seria morte celular e necrose das células próximas ao sítio de infecção (resposta de hipersensibilidade - $\mathrm{RH}$ ), acúmulo de compostos fenólicos tóxicos, modificações da parede celular pela inserção, de ou com a formação de, barreiras físicas, tais como aposições ou papilas e finalmente a síntese de compostos antibióticos específicos, tais como as fitoalexinas (Pascholati \& Leite, 1994). Esta seqüência não é regra, visto que em alguns tipos de interações fitopatogênicas (tomate vs Verticillium, tomate vs Fusarium), as respostas defensivas são basicamente físicas, devido ao acúmulo de compostos antibióticos ser quase inexpressível (Elgersma \& Liem, 1989). Porém, em muitos casos o acúmulo de compostos fenólicos, tais como ácido ferúlico, ocorre sem o envolvimento da fenilalanina (rota dos fenilpropanóides) (Grisebach, 1981, Hahlbrock \& Schell, 1989).

Estudos de hibridização RNA-RNA em folhas jovens de batata demonstraram diferenças temporais e espaciais no acúmulo de mRNA codificado para fenilalanina amônia liase em resposta a infecção (Cuypers et al., 1988). Inúmeros trabalhos publicados na literatura confirmaram a elevação da FAL como indicador da estratégia defensiva (Bell et al., 1986; Cramer et al., 1985; Dixon et al., 1983; Dixon \& Bendal; 1978; Dixon et al., 1981; Fritzemeier et al., 1987; Jahnen \& Hahlbrock, 1988; Lawton \& Lamb, 1987; Pascholati et al., 1985; Pascholati et al., 1986). Entretanto, para Nicholson \& Hammerschmidt (1992) é necessário cautela ao se afirmar que a expressão da FAL seja sempre um indicativo de resistência ou envolvimento no metabolismo de compostos fenólicos, como parte da estratégia defensiva da planta. 
Conclusivamente, os compostos fenólicos estão associados às respostas de defesas passivas e ativas da planta. Entretanto, devido à sua presença universal na maioria das plantas vasculares e ao acúmulo dos mesmos em interações compatíveis e incompatíveis, a contribuição relativa de alguns grupos ou classes de compostos fenólicos na expressão da resistência ou na restrição ao desenvolvimento em interações compatíveis ainda apresenta inúmeros pontos em questão (Nicholson \& Hammerschmidt, 1992). Pesquisas futuras devem ser direcionadas na localização e concentração destes compostos na planta, bem como nas relações destes compostos com outros sistemas defensivos da planta. 


\section{EFEITO DE EXTRATOS DO ALBEDO DE Citrus sinensis NA GERMINAÇÃO, FORMAÇÃO DE APRESSÓRIO E CRESCIMENTO MICELIAL DE Phyllosticta citricarpa in vitro}

\section{Resumo}

Procurou-se avaliar o efeito in vitro de extratos (aquoso, etanólico e metanólico) de albedo de Citrus sinensis na germinação, formação de apressório e crescimento micelial de Phyllosticta citricarpa, fase anamórfica de G. citricarpa, agente causal da mancha preta dos citros. Os experimentos foram conduzidos em condições de laboratório em delineamento inteiramente casualizado, esquema fatorial (3 extratos, 5 concentrações) com cinco repetições. As concentrações dos extratos variaram de 0,001 a $10 \mathrm{mg} \mathrm{mL}^{-1}$. Para estudar os efeitos dos extratos na germinação de picnidiósporos e formação de apressório, gotas de $40 \mu \mathrm{L}$ de cada concentração foram retiradas e misturadas com $40 \mu \mathrm{L}$ de uma suspensão de picnidiósporos $\left(2 \times 10^{4}\right.$ picnidiósporos $\mathrm{mL}^{-1}$ ) e colocadas em lâminas de microscopia recobertas com filme de poliestireno e incubadas em placas de Petri com papel de filtro umedecido por $12 \mathrm{~h}$ sob luz fluorescente contínua a $26^{\circ} \mathrm{C}$ em câmara de crescimento. A germinação e a formação de apressórios, foram avaliadas a partir da contagem de 50 picnidiósporos por campo microscópico. Para os ensaios de inibição do crescimento micelial, a partir de soluções-estoque (100 $\mathrm{mg} \mathrm{mL}^{-1}$ ) dos extratos, retiraram-se alíquotas variando de 0 a $2 \mathrm{~mL}$, que foram incorporadas ao meio batata-dextrose-ágar, juntamente com um disco de 
micélio ( $1 \mathrm{~cm}$ diâmetro), em placas de Petri. $\mathrm{O}$ crescimento micelial foi avaliado 20 dias após incubação em câmara de crescimento $\left(26^{\circ} \mathrm{C}\right.$, com fotoperíodo de 12 h). A quantificação dos compostos fenólicos, presentes nos extratos foi efetuada pelo uso do reagente de Folin-Ciocalteau, usando o ácido clorogênico como padrão. Os resultados mostraram que para os extratos etanólicos e metanólicos, a concentração de $10 \mathrm{mg} \mathrm{mL}^{-1}$ apresentou atividade fungicida, inibindo a germinação, formação de apressório e o crescimento micelial de $P$. citricarpa em 100\% após 20 dias de incubação. Foi também observado que os extratos de albedo de laranja testados exibem, a depender da concentração, ação fungistática ou fungicida. As possíveis razões para o sucesso dos extratos de albedo no controle in vitro de $P$. citricarpa são discutidas no texto.

\section{Summary}

\section{Effects of albedo's extracts of Citrus sinensis on the germination, apressorium formation and mycelial growth of Phyllosticta citricarpa in vitro}

This study was carried out to investigate the effects of albedo extracts (aqueous, ethanolic and methanolic) of Citrus sinensis on the germination, apressorium formation and mycelial growth of Phyllosticta citricarpa, anamorphic phase of G. citricarpa, causal agent of citrus black spot. The experiment was set in a randomized complete design ( 3 extracts types and 5 concentrations) with five replicates, under laboratory conditions. To study the effects of extracts on the germination of pycnidiospore and apressorium formation, droplets of 40 $\mu \mathrm{l}$ from each extract concentrations (ranging from 0.001 to $10 \mathrm{mg} \mathrm{mL}^{-1}$ ) were mixed with $40 \mu \mathrm{l}$ pycnidiospore suspension $\left(2 \times 10^{4} \mathrm{~mL}^{-1}\right)$ and placed onto the 
surface of glass slides coated with polystyrene and incubated under fluorescent light at $26^{\circ} \mathrm{C}$ for $12 \mathrm{~h}$ inside growth chambers. In this bioassay, 50 pycnidiospores were quantified in each microscopic field. From stock-solutions (100 $\mathrm{mg} \mathrm{mL}^{-1}$ ) of extracts, fractions (ranging from 0 to $2 \mathrm{~mL}$ ) were placed with mycelium disc ( $1 \mathrm{~cm}$ diameter) on PDA medium inside Petri dishes to determine the fungal growth. Petri dishes were incubated at $26^{\circ} \mathrm{C}$ under photoperiod conditions (12 $\mathrm{h}$ light) during 20 days. To quantify the concentration of phenols in the extracts by the Foil-Ciocalteau method, chlorogenic acid was used as standard. The results showed that the ethanolic and methanolic extracts at 10 $\mathrm{mg} \mathrm{mL}^{-1}$ exhibited fungicidal activity, inhibiting completely the germination, apressorium formation and mycelial growth of $P$. citricarpa. It was observed that ethanolic and methanolic orange albedo extracts exhibited, depending upon the concentration, fungicidal or fungistatic activity. The possible reasons to the success of albedo's extracts for in vitro control of $P$. citricarpa are discussed in the text. 


\subsection{Introdução}

O Brasil é considerado o maior produtor mundial de citros e maior exportador de suco de laranja (Critrusfeat, 2001; Pollack, 2001). No país, o Estado de São Paulo é o principal produtor, respondendo por $80 \%$ da produção brasileira (Gama et al., 2000). Mesmo assim, de acordo com Almeida (2002) ainda é considerado um país marginal no comércio mundial de frutas frescas, pois participa apenas com $0,5 \%$ nesse comércio. Contudo, a potencialidade da fruticultura no Brasil é muito grande, e aliada ao tamanho da produção, a diversidade de produtos, à condições favoráveis de clima, solo e época estratégica das safras, podemos considerar a possibilidade de inserção no mercado internacional com inúmeras vantagens comparativas em relação a outros países da América Latina. Entretanto, existem inúmeros entraves, apenas para citar alguns, temos: uma grande deficiência no controle fitossanitário; o baixo padrão de qualidade dos produtos sob o enfoque de exigências do consumidor externo; pouca pesquisa quanto à variedade e tecnologia de produção e pós-colheita e um mercado externo concentrador e que impõe barreiras alfandegárias à exportação de produtos hortícolas e frutícolas brasileiros (Henz, 2002).

Dentro deste contexto, no Brasil como em outros países, apesar do avanço tecnológico, grandes perdas de frutas e hortaliças em pós-colheita continuam a ocorrer e na maioria dos casos, diversos fatores podem ser apontados como relevantes, entre os quais citam-se o manejo inadequado dos produtos, condições desfavoráveis de armazenamento e comercialização, modificações físicas e bioquímicas durante o processo de senescência e atividade de microrganismos oportunistas causadores de podridões (Kretzschmar, 1991). Inúmeros microrganismos, principalmente fungos e bactérias, estão associados às podridões que ocorrem em pós-colheita em produtos frutícolas e hortícolas (Wilson \& Wisniwski, 1994). Estes microrganismos penetram na maioria das vezes através de ferimentos 
acidentais provocados durante a colheita, transporte e armazenamento, ou pelas aberturas naturais do fruto ou estruturas florais, permanecendo em estado latente até o amadurecimento quando então causam a podridão (Ippolito \& Nigro, 2000).

Assim sendo, em função da importância da mancha preta dos citros (MPC), causada pelo fungo Guignardia citricarpa (anamorfo: Phyllosticta citricarpa), medidas de controle economicamente viáveis devem ser encontradas. A importância da MPC, do ponto de vista econômico, reside no fato de que atinge os frutos das variedades mais apreciadas, para consumo in natura, principalmente a laranja 'Pera', (variedade da citricultura paulista, com $41 \%$ do total das plantas, de acordo com Amaro \& Maia, 1997), depreciando-os comercialmente na aparência através de manchas, que apesar de limitadas a casca (flavedo), inviabilizam a sua comercialização, principalmente para o mercado externo (Góes et al., 2000, Góes, 2002). Além disso, devido ao longo período de suscetibilidade apresentado pelos frutos, são necessárias diversas aplicações de fungicidas, aplicados isoladamente ou associados a óleo mineral, o que eleva o custo final da produção (Góes, 1998). Atualmente, devido à existência de condições ambientais favoráveis àformação do inóculo, a MPC já foi constatada em cerca de 44 municípios do Estado de São Paulo (Fundecitrus, 2000), podendo no entanto ter uma abrangência geográfica bem maior nos próximos anos (Góes et al., 2000). Como forma de controle para G. citricarpa e fitopatógenos de pós-colheita, tratamentos químicos, térmicos, práticas culturais visando reduzir o inóculo no campo, e radiação têm sido utilizados. Dentre estes, os tratamentos químicos com fungicidas são os mais utilizados tanto em pré quanto em pós-colheita (Janisiewicz, 1996).

No Brasil e a exemplo de outros países, o uso de fungicidas sistêmicos do grupo dos benzimidazóis em larga escala tem levado à seleção de linhagens fúngicas resistentes (Ghini \& Kimati, 2000). Além disso, no Brasil, muitos produtos químicos testados e ou suas misturas não possuem registro para uso em pós-colheita (Agrofit, 2002), o que agrava a situação para o caso 
de produtos destinados à exportação, uma vez que existem diferenças entre as populações dos países consumidores em relação ao uso de determinados fungicidas, bem como na variação da dose mínima residual tolerada (Almeida, 2002). Desta forma, de acordo com Henz (2002), como existe hoje em dia uma maior preocupação dos consumidores brasileiros e estrangeiros, principalmente por produtos sem resíduos químicos tóxicos, microbiológicos ou com outros tipos de contaminação, inúmeros trabalhos estão sendo realizados buscando encontrar métodos de controle alternativos de fitopatógenos (Franco \& Bettiol, 2000; Janisiewicz, 1996; Teewari \& Nayak, 1991; Zambonelli et al., 1996).

Sabe-se que extratos de certas espécies vegetais possuem atividade antimicrobiana (Cowan, 1999). Extratos brutos e óleos essenciais de diversas espécies de plantas medicinais, foram testados quanto a sua atividade elicitora da síntese de fitoalexinas e atividadade antifúngica por Stangarlin et al. (1999). Estes autores verificaram que os extratos brutos de pitanga, cânfora, poejo, romã e cardo santo foram os mais efetivos em induzir o acúmulo da fitoalexina gliceolina, bem como de duas frações fungitóxicas bem definidas nos extratos de erva cidreira, cânfora e alfavaca.

O uso do extrato de albedo e flavedo na inibição do crescimento micelial de Phomopsis citri foi relatado por El-Tobshy \& Sinclair (1964).

Murdoch \& Allen (1960 citado em Brodrick, 1971) relataram que o limoneno obtido da casca de laranja, em concentrações variando de 0,02 a 0,1 \%, foi tóxico ao fungo Zygosaccharomyces spp. Em 1971, Brodrick também relatou o potencial do limoneno, extraído do albedo e do flavedo de laranja para o controle de Guignardia citricarpa (forma anamórfica Phyllosticta citricarpa), comprovando o efeito antifúngico deste composto.

Observa-se, através destes trabalhos que ocorrem efeitos fungitóxicos (fungicida / fungistático) em experimentos realizados in vitro e in vivo, e que extratos de origem vegetal têm um grande potencial como agentes antimicrobianos. Assim, o presente trabalho teve como objetivo avaliar o efeito antifúngico, in vitro, de extratos do albedo de laranja em relação a $P$. citricarpa. 


\subsection{Material e métodos}

\subsubsection{Obtenção e extração dos extratos do albedo}

Frutos, com idade aproximada de 10 meses (50 frutos de cada variedade), de laranja Pêra, Valência e Natal (Citrus sinensis (L.) Osbeck), assintomáticos e com sintomas de MPC, foram coletados de plantas adultas (8 anos de idade) infectadas com Guignardia citricarpa da fazenda Oryçanga, no município de Mogi-Guaçu-SP. Em laboratório (Fisiologia do parasitismo, Setor de Fitopatologia / ESALQ/USP), a separação do flavedo (epicarpo ou casca) e albedo (mesocarpo) foi efetuada com auxílio de uma faca. Para frutos com sintomas de MPC, o flavedo e o albedo foram obtidos, com auxílio de vazadores metálicos, a partir da área circunscrita àlesão do tipo mancha dura. Em seguida, após a separação, determinou-se o peso da matéria fresca do albedo e do flavedo, que foram homogeneizados, separadamente em liquidificador (Arno, Brasil) na menor velocidade, durante 1 min e a massa fresca novamente determinada. A seguir, após secagem em estufa $\left(65^{\circ} \mathrm{C}\right.$ até peso constante) para cada grama de albedo ou flavedo seco foi adicionado 1 $\mathrm{mL}$ de água destilada, álcool etílico P.A. ou uma solução de álcool metílico acidificada com HCl (2 \%) de acordo com Leite \& Nicholson (1992). Logo após, os homogeneizados (pó seco do albedo ou flavedo + solventes) foram aquecidos em banho-maria $\left(60^{\circ} \mathrm{C}\right.$ durante $10 \mathrm{~min}$ ), sendo filtrados em papel de filtro Whatman no.1 a vácuo, e em seguida reduzidos próximo à secura em evaporador rotativo (Marconi, Brasil) a $40{ }^{\circ} \mathrm{C}$, sob vácuo (Musumeci \& Oliveira, 1975) e finalmente liofilizados (Lyovac, Alemanha) e armazenados em geladeira $\left(5-10^{\circ} \mathrm{C}\right)$ até o uso (Nelly et al., 2001). 


\subsubsection{Patógeno}

O fungo Phyllosticta citricarpa (McAlpine) Petrak (teleomorfo: Guignardia citricarpa Kiely), isolado IAC 13/96 (cedido gentilmente pelo pesquisador, Carlos Aguilar-Vildoso do Centro de Citricultura Sylvio MoreiraIAC, Cordeirópolis-SP.) foi repicado em BDA (Batata-dextrose-ágar, Oxoid, Inglaterra) e cultivado em câmara de crescimento (Marconi, Brasil) a $26^{\circ} \mathrm{C}$, sob alternância de luz, $12 \mathrm{~h}$ de claro / $12 \mathrm{~h}$ de escuro (lâmpada fluorescente) durante 25 dias.

Para a obtenção dos picnidiósporos, o fungo foi crescido em folhas (cortadas com um vazador metálico $\operatorname{com~} 2 \mathrm{~cm}$ de diâmetro) de limão Siciliano, as quais foram autoclavadas em água destilada por $20 \mathrm{~min}$ e colocadas em placas de Petri com meio ágar-água ( $1,5 \%)$, sendo 5 fragmentos por placa. Em pontos próximos ao fragmentos de folha, foram colocados discos de micélio (colônias com 20 dias de crescimento em BDA). Ao final de 14 dias observou-se a presença de picnídios na superfície das folhas. A viabilidade dos picnidiósporos foi observada em lâminas de poliestireno, em microscópio ótico (aumento de $400 \mathrm{x}$ ) e confirmada a partir da germinação dos mesmos, em $\mathrm{H}_{2} \mathrm{O}$ (destilada esterilizada), após $12 \mathrm{~h}$ de incubação em câmara de crescimento (Marconi, Brasil) a $25{ }^{\circ} \mathrm{C}$. Os piciniósporos foram obtidos de uma massa gelatinosa presente no ostíolo dos picnídios (Figura 2), de acordo com McOnie (1964, 1967) e Blanco (1999). 


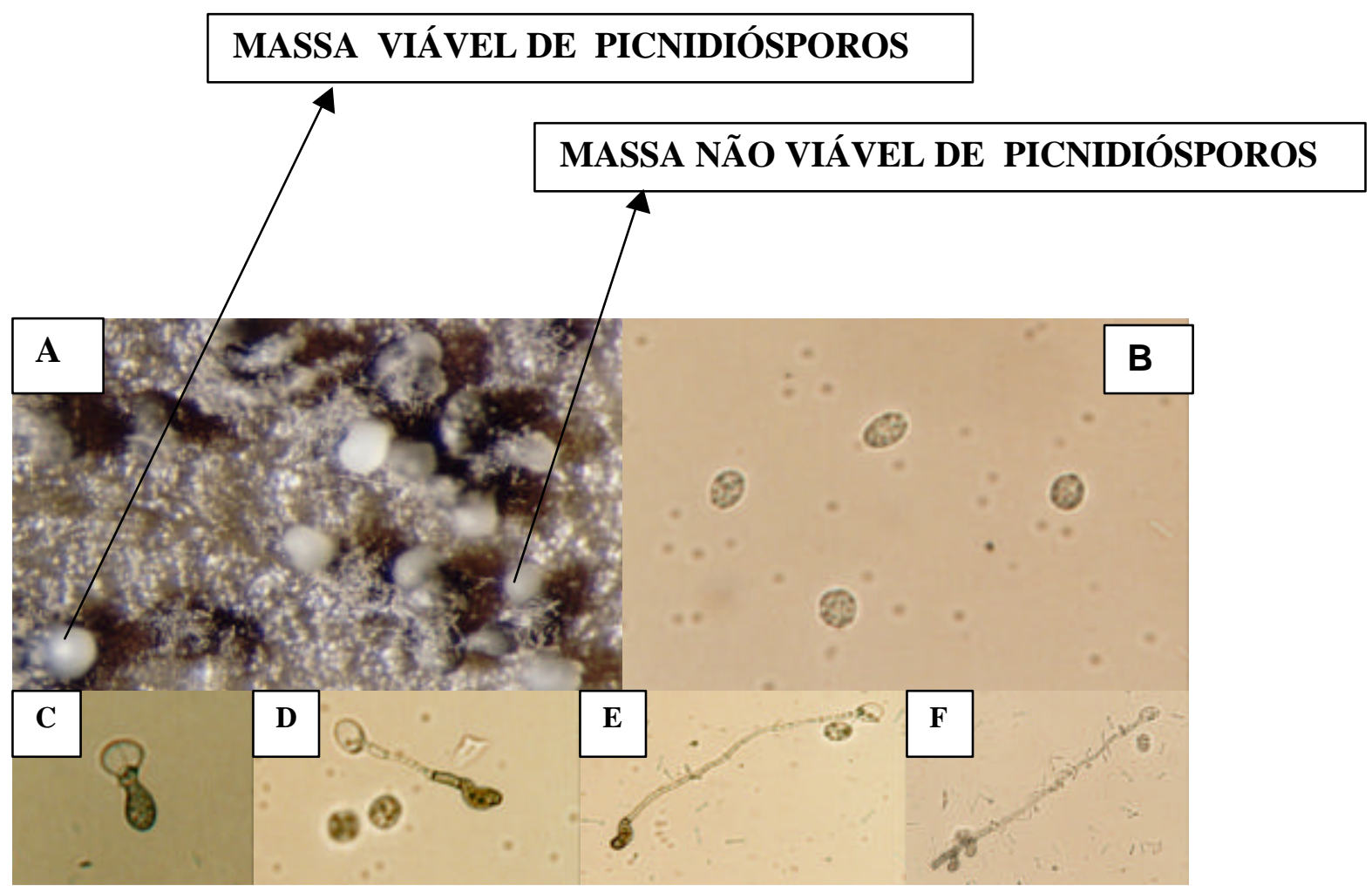

Figura 2 - Germinação de picnidiósporos e formação de apressório de Phyllosticta citricarpa (teleomorfo: Guignardia citricarpa) em água destilada esterilizada, a partir de picnídios formados em folhas autoclavadas de limão Siciliano. Massa de picnidiósporos na superfície do ostíolo do picnídio de $P$. citricarpa (A); Picnidiósporos não germinados de $P$. citricarpa (B); Sequência de eventos durante a germinação de picnidiósporos e formação de apressório de $P$. citricarpa $(\mathrm{C}-\mathrm{F})$. Dimensões dos picnidiósporos 12,3 x 6,2 $\mu \mathrm{m}$. Figura 2A (aumento de $100 \mathrm{x}$ ), 2B -2F (aumento de $400 \mathrm{x}$ ). 


\subsubsection{Análise qualitativa para compostos fenólicos do albedo}

Esta análise foi efetuada adotando o método descrito por Mattos (1988). O método é indicado para a detecção de fenóis simples e baseou-se em teste químico utilizando-se uma solução de cloreto férrico $\left(0,1 \mathrm{M}\right.$ de $\left.\mathrm{FeCl}_{3}\right)$ em $\mathrm{HCl} 0,1 \mathrm{M}$. Assim sendo, $10 \mathrm{~g}$ de pó de extrato de albedo liofilizado de laranja Pêra-Rio, Valência e Natal, foram colocados separadamente em água destilada e deixados em geladeira por $12 \mathrm{~h}$. Em seguida após filtragem em papel de filtro Whatman no. 1 , ao filtrado ( $3 \mathrm{~mL}$ ) em tubo de ensaio, acrescentaram-se 3 gotas da solução de cloreto férrico. Procedeu-se agitação em Vórtex (Marconi, Brasil) durante $1 \mathrm{~min}$, sendo logo após efetuada a observação visual direta do resultado no tubo de ensaio. As colorações resultantes foram comparadas com as informações existentes na literatura (Dey \& Harborne, 1989; Harborne, 1998) e consideradas como indicativo da presença ou não de compostos fenólicos nos extratos avaliados.

\subsubsection{Análise quantitativa do conteúdo total de compostos fenólicos do albedo e flavedo}

Dos extratos liofilizados de albedo e flavedo, foram retirados 100 $\mathrm{mg}$, que foram diluídos em $1 \mathrm{~mL}$ de água destilada. A seguir, alíquotas de 150 $\mu \mathrm{l}$ destas diluições foram retiradas e acrescidas de $1,5 \mathrm{~mL}$ de carbonato de sódio $2 \%$ em tubo de ensaio. Após $5 \mathrm{~min}$, foram adicionados aos tubos de ensaio, sob agitação, $150 \mu \mathrm{l}$ de solução de reagente Folin-Ciocalteau $2 \mathrm{~N}$ diluído em água destilada $(1: 1, \mathrm{v} / \mathrm{v})$ (Bray \& Thorpe, 1954). Todas as leituras (absorbância $750 \mathrm{~nm}$ ) das amostras foram realizadas em espectrofotômetro (Hitachi-U2000) e efetuadas 30 min após a adição do reagente Folin-Ciocalteau (Baptista, 2000). Como referência, foi utilizado metanol acidificado com $\mathrm{HCl}$ (2\%), etanol e água em substituição aos extratos. A concentração de fenóis em cada amostra testada, foi expressa em termos de equivalentes $\mu \mathrm{g}$ de ácido 
clorogênico por $g$ de extrato. A concentração de ácido clorogênico foi determinada utilizando-se curva padrão $\left(y=0,0023 x-0,0011, R^{2}=0,99\right.$, apêndice 1), previamente elaborada a partir do ácido em água destilada, variando de 0 a $300 \mu \mathrm{g} \mathrm{mL}^{-1}$ em função de sua absorbância a 750 nm (Lopez \& Pascholati 1992).

\subsubsection{Detecção da atividade antifúngica dos extratos}

\subsubsection{Influência na germinação de picnidiósporos e formação de apressório}

A partir das soluções estoque ( $100 \mathrm{mg} / \mathrm{mL}$ de $\mathrm{H}_{2} \mathrm{O}$ destilada) dos extratos foram preparadas diluições (1/10 a 1/100.000) em água destilada esterilizada. Logo após, alíquotas de $20 \mu$ das diluições foram retiradas e

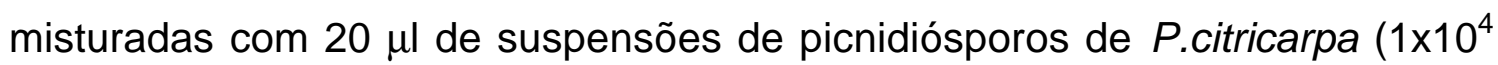
picnidiósporos $\mathrm{mL}^{-1}$ de Tween 80 0,1\%:), e colocadas em lâminas de microscopia recobertas com filme de poliestireno (Leite \& Nicholson, 1992). Como controle foi utilizada água destilada esterilizada. A seguir as lâminas foram colocadas no interior de placas de Petri $(9 \mathrm{~cm}$ de diâmetro) esterilizadas, contendo um chumaço de algodão embebido em água destilada, seladas com filme de PVC e incubadas em câmara de crescimento (Marconi, Brasil) à temperatura de $26{ }^{\circ} \mathrm{C}$, com luminosidade constante por $12 \mathrm{~h}$. Após este período, a percentagem de germinação foi avaliada através da observação em microscópio ótico (aumento de $200 \mathrm{x}$ ). Considerou-se como germinados os picnidiósporos com tubo germinativo de tamanho igual ou superior ao comprimento do picnidiósporo não germinado. Antes da leitura, em cada lâmina, foram adicionados $10 \mu \mathrm{l}$ de uma solução contendo $27 \mathrm{~mL}$ de metanol, $63 \mathrm{~mL}$ de água e $15 \mathrm{~mL}$ de formol 37\%, visando paralisar a germinação dos picnidiósporos (Toit du \& Rautenbach, 2000). 


\subsubsection{Influência no crescimento micelial}

A partir de soluções estoque (100 $\mathrm{mg} \mathrm{mL}^{-1}$ de $\mathrm{H}_{2} \mathrm{O}$ destilada) do liofilizado dos extratos, foram retiradas alíquotas de $0,5 \mathrm{~mL}$ que foram usadas no preparo das diluições de 1/10 a 1/100.000 em água destilada esterilizada. Posteriormente, $1 \mathrm{~mL}$ de cada diluição foram incorporados a 1,5 $\mathrm{mL}$ de BDA fundente $\left(45^{\circ} \mathrm{C}\right.$ em banho-maria) em placas de petri tipo Pyrex. Em seguida após a solidificação, discos de micélio de $1 \mathrm{~cm}$ de diâmetro de P.citricarpa (cultivado em BDA, como descrito no item 3.2.2) foram transferidos para o centro das placas contendo BDA mais extrato ou $1,5 \mathrm{~mL}$ de BDA acrescido de $1 \mathrm{~mL}$ de $\mathrm{H}_{2} \mathrm{O}$ destilada esterilizada, no caso da testemunha. Após 20 dias de incubação a $26{ }^{\circ} \mathrm{C}$, luz fluorescente, com alternância de luminosidade $(12 \mathrm{~h}$ claro e $12 \mathrm{~h}$ escuro) foi determinado o diâmetro das colônias utilizando-se um paquímetro, subtraindo-se o diâmetro do disco de micélio inicial (Quiroga et al., 2001). Devido ao crescimento irregular das colônias, quatro medidas de diâmetro foram realizadas. A fungitoxidade dos extratos aquoso, etanólico e metanólico foi determinada em termos de percentagem de inibição do crescimento da colônia, que foi calculada de acordo com Edginton et. (1971) através da fórmula:

$$
\text { Percentagem de inibição do crescimento }(\mathrm{Pl} \%)=\frac{\text { DC }- \text { DT }}{\text { Dc }} \times 100 \text {; }
$$

Onde, Dc é o diâmetro médio de $P$. citricarpa no controle e Dt é o diâmetro médio de $P$. citricarpa nos tratamentos testados.

Para determinar se os extratos testados apresentavam atividade fungicida ou fungistática, quando ao término do primeiro experimento, os discos de micélio utilizados foram transferidos para placas com BDA, sem a presença dos extratos, que foram incubadas em câmara de crescimento a $26^{\circ} \mathrm{C}$, com luz fluorescente constante, durante $96 \mathrm{~h}$ (Quiroga et al., 2001). 


\subsubsection{Influência na formação de picnídios em folhas autoclavadas}

Para testar o efeito inibitório dos extratos de albedo na formação de picnídios, folhas de limão Siciliano, foram cortadas com um vazador metálico ( $2 \mathrm{~cm}$ diâmetro), lavadas em água corrente, autoclavadas por 20 min e os fragmentos colocados em placas de Petri com meio ágar-água (1,5\%). Em cada placa, foram colocados 5 fragmentos, com a superfície abaxial em contato com o meio. Posteriormente, foram adicionados sobre a superfície de cada fragmento foliar $10 \mu \mathrm{L}$ de soluções-estoque de cada extrato liofilizado, com concentrações que variaram de 100 (0\%), 4 (25\%), 2 (50\%), 1,3 (75\%) e 1 $(100 \%) \mathrm{mg} \mathrm{mL}^{-1}$ de água destilada esterilizada. Posteriormente, discos de micélio ( $1 \mathrm{~cm}$ de diâmetro), retirados da zona de crescimento de colônias, cultivadas conforme o item 3.2.2, foram colocados em pontos adjacentes ao fragmentos foliares. As placas foram seladas com filme de PVC e incubadas a $26^{\circ} \mathrm{C}$ sob luz fluorescente, com alternância de luminosidade (12 h claro e $12 \mathrm{~h}$ escuro) em câmara de crescimento (Marconi, Brasil) durante 18 dias. Após este período, com auxílio de microscópio ótico (aumento de $200 \mathrm{x}$ ) foi avaliado o número de picnídios formados na superfície dos fragmentos, em cinco campos microscópicos. Como controle positivo foi utilizado o benomil囚 $(0,35 \mathrm{~g}$ do p.a. $\mathrm{L}^{-1}$; Góes, 1998) e negativo água destilada esterilizada.

\subsubsection{Análise cromatográfica dos extratos e detecção da atividade antifúngica}

Os extratos liofilizados foram diluídos em água destilada $\left(\mathrm{AgH}_{2} \mathrm{O}\right)$, etanol P.A. (EtOH) ou metanol (MeOH), na proporção de $100 \mu \mathrm{g}$ peso seco de albedo por $\mathrm{mL}^{-1} \mathrm{e}$, as amostras usadas em análise de cromatografia em camada delgada (TLC). As placas foram pré-lavadas com clorofórmio / metanol (1:1, v/v) (Lopez \& Pascholati, 1992), e expostas à secagem em capela com circulação de ar. Em seguida, foram pipetados $10 \mu \mathrm{l}$ das referidas amostras 
colocadas em placas de sílica gel Whatman $\left(\mathrm{SiO}_{2} \times \mathrm{H}_{2} \mathrm{O} 20 ; 20 \mathrm{~cm}\right.$; G $60 \mathrm{~F}_{250}$ $\mathrm{nm}$ ) com indicador de luminescência a cerca de $0,5 \mathrm{~cm}$ acima da fase móvel. As placas foram imersas em solução (n-butanol / ácido acético / água, 4:1:1, v/v/v, Musumeci \& Oliveira, 1975) que atuou como fase móvel (Collins et al., 1990). As cubas de cromatografia receberam $10 \mathrm{~mL}$ da fase móvel $(1,5 \mathrm{~cm}$ de altura) e quando a fase móvel atingiu $0,5 \mathrm{~cm}$ da extremidade superior de cada placa, estas foram retiradas das mesmas. A revelação foi efetuada sob luz ultravioleta (365 e $254 \mathrm{~nm}$ ) após secagem das placas, com secador de cabelo, o que permitiu a visualização das manchas dos eluentes cromatografados dos compostos dos extratos. Finalmente, objetivando também a visualização e documentação dos eluentes cromatografados, as placas foram imersas em uma mistura de água destilada, metanol, ácido sulfúrico concentrado e vanilina (135 $\mathrm{mL} \mathrm{H} \mathrm{H}_{2} \mathrm{O}$ destilada $+135 \mathrm{~mL} \mathrm{MeOH}+30 \mathrm{~mL}$ de $\mathrm{H}_{2} \mathrm{SO}_{4}$ concentrado $+3 \mathrm{~g}$ de vanilina), de acordo com Sherma \& Fried (1996).

Visando o cálculo dos valores dos Rfs (Schriner et al. 1983), foi utilizada a seguinte relação:

$$
\mathrm{Rf}=\frac{\text { distância percorrida pela mancha desde a origem }}{\text { distância percorrida pela fase móvel desde a origem }}
$$

Os Rfs calculados foram comparados com os existentes na literatura (Ribéreau-Gayon, 1972; Harborne, 1998; Waterman \& Mole, 1994).

Finalmente, as placas de TLC foram aspergidas com uma suspensão de Penicillium digitatum $\left(10^{6}\right.$ conídios $\mathrm{mL}^{-1}$ em Tween $0,1 \%$ ) misturadas em meio líquido Czapek-Dox (glicose $20 \mathrm{~g}$, nitrato de sódio $2 \mathrm{~g}$, fosfato dibásico de potássio $1 \mathrm{~g}$, sulfato de magnésio heptahidratdado $0,5 \mathrm{~g}$, cloreto de potássio $0,5 \mathrm{~g}$, sulfato ferroso $0,01 \mathrm{~g} \mathrm{em} 1$ litro de água, $\mathrm{pH}$ ajustado para 7,3 - Alef ,1995) e colocadas no interior de placas de petri $(20 \mathrm{~cm}$ diâmetro) esterilizadas, contendo algodão umedecido e incubadas a $26{ }^{\circ} \mathrm{C}$ durante 48 h (Lopez \& Pascholati, 1992). Após este período foram observadas a formação ou não de zonas de inibição nas áreas das bandas 
cromatografadas. As manchas dos eluentes com zonas de inibição foram raspadas, ressuspensas em $1 \mathrm{~mL}$ de etanol ou metanol P.A., filtradas em papel de filtro Whatman no. 1 e submetidas a uma análise espectrofotométrica (faixa do espectro visível e ultravioleta), de acordo com Lopez \& Pascholati (1992), objetivando a obtenção do espectro de absorção, que foi comparado com os existentes na literatura (Silverstein \& Bassler, 1966).

\subsubsection{Análise estatística}

Foram utilizados delineamentos inteiramente casualizados para todos os ensaios de laboratório. $O$ esquema fatorial: 3 (extratos) +1 (controle) $x$ 5 (diluições) em 5 repetições foi adotado para os experimentos dos ítens 3.2.5.1 e 3.2.5.2. Ao passo que para o item 3.2.5.3, foi usado um ensaio inteiramente casualizado simples com 4 repetições.

Os dados expressos em percentagem foram transformados em arco seno $(x)^{1 / 2}$ e os dados de contagem foram transformados em raiz quadrada (x) antes da análise de variância (Steel \& Torrie, 1960). Aos dados quantitativos (diluições) aplicou-se uma análise de regressão e aos dados qualitativos (extratos e número de picnídios) foi aplicado o teste de Tukey a $5 \%$ de probabilidade (Gomes, 1995).

\subsection{Resultados e discussão}

\subsubsection{Análise qualitativa para compostos fenólicos do albedo}

A análise qualitativa do conteúdo fenólico nos diferentes extratos, utilizando-se a técnica de Mattos (1988), revelou-se positiva quando comparada com a literatura (Harborne, 1998) e foi considerada como indicativo da presença de compostos fenólicos nos extratos avaliados. Os filtrados dos extratos de albedo, após a adição do cloreto férrico, apresentaram um sobrenadante com coloração azul escura com tons avermelhados indicando a presença de 
compostos fenólicos (coloração azul escura avermelhada) e a formação de um precipitado escuro (dados não mostrados) e taninos (precipitado escuro). Este tipo de análise, apesar de bastante subjetiva (Mattos, 1988; Waterman \& Mole, 1994; Harborne, 1998), é um dos procedimentos clássicos mais usados no estudo de fenóis e uma das primeiras análises efetuadas em extratos vegetais, o que permite uma noção geral acerca da composição do extrato a ser estudado (Harbone, 1998). A subjetividade deste tipo de análise se baseia no fato de que a presença de compostos fenólicos no estado livre (ex. hidroquinona, catecol, orcinol e pirogalol) é um fato extremamente raro em tecidos vegetais, visto que estes compostos em função da presença de radicais reativos ligados ao anel aromático, apresentam uma tendência de se ligarem a metais, outros fenólicos e proteínas formando complexos (Ribéreau-Gayon, 1972; Harborne, 1998). Desta forma, a presença de um constituinte pode mascarar a cor indicativa da presença de outro em um mesmo substrato (Ribéreau-Gayon, 1972; Mattos, 1988).

\subsubsection{Análise quantitativa do conteúdo total de compostos fenólicos do albedo e flavedo}

Com o objetivo de se mensurar a concentração fenólica nos extratos de albedo de laranjas Pêra-Rio, Valência e Natal e flavedo de laranja Pêra-Rio, obteve-se uma curva padrão $\left(Y=0,0023 x-0,0011, R^{2}=0,99\right.$, apêndice 1) para ácido clorogênico e a partir desta estimou-se a concentração fenólica destes extratos. Optou-se pelo ácido clorogênico como padrão devido a sua semelhança química estrutural com outros fenóis simples (Bray \& Thorpe, 1954; Ribéreau-Gayon, 1972). O uso do reagente de Folin-Ciocalteau mostrouse bastante promissor, na quantificação de fenóis em albedo de laranja (Tabela 2), apresentado resultados altamente significativos, quando correlacionadas as diluições utilizadas e a quantidade de eq. ug ác. clorogênico encontrada (Apêndice 1). Isto se deve ao fato de que o reagente utilizado na quantificação 
dos fenóis é extremamente sensível (Julkunen-Tiitto, 1985; Harborne, 1998). Este reagente consiste em uma mistura de fósforo ligado a tungstênio $\left(\mathrm{H}_{3} \mathrm{PW}_{12} \mathrm{O}_{40}\right)$ e fósforo ligado a molibdênio $\left(\mathrm{H}_{3} \mathrm{PMo}_{12} \mathrm{O}_{40}\right)$ acidificados, os quais são reduzidos comitantemente com a oxidação dos fenóis, a uma mistura de óxidos de tungstênio $\left(\mathrm{W}_{8} \mathrm{O}_{23}\right)$ e molibdênio $\left(\mathrm{Mo}_{8} \mathrm{O}_{23}\right)$ de coloração azul (Bray \& Thorpe, 1954). A cor azul produzida ( $\lambda_{\max }$ entre 725 a $750 \mathrm{~nm}$ ) é proporcional a concentração de compostos fenólicos presentes no material analisado.

Os Resultados (Tabela 1) mostraram que a concentração fenólica no extrato aquoso é aproximadamente $50 \%$ inferior às concentrações fenólicas do extrato metanólico para a variedades de laranja avaliadas. No tocante a concentração de fenóis nos extratos etanólicos esta proporção foi mantida apenas para a variedade Pêra-Rio. Isto corrobora parcialmente com as observações de Harborne (1998) de que a extração de compostos fenólicos em tecidos vegetais é mais eficaz quando se utiliza como solvente álcool aquecido em banho-maria em temperaturas em torno de $45^{\circ} \mathrm{C}$, evitando-se assim perda de material devido àação de polifenoloxidases e peroxidases, que acarretam a oxidação enzimática no extrato vegetal (Ribéreau-Gayon, 1972; Robards et al., 1999).

Desta forma optou-se pela extração alcoólica (etanólica e metanólica), já consagrada na literatura (Ribéreau-Gyaon, 1972; Harborne, 1998; Waterman \& Mole, 1994). Além disso, o uso do etanol e metanol têm a vantagem de serem mais facilmente eliminados quando concentrados à vácuo (Ribéreau-Gayon, 1972).

Robards et al. (1999) afirmaram que a composição fenólica de frutos e vegetais é determinada por fatores genéticos e ambientais. Esta observação talvez possa explicar as diferenças quantitativas de fenóis observadas no albedo das variedades testadas (Tabela 2). Foi constatado (dados não mostrados) que em frutos com a mesma idade e diâmetro, a massa de albedo retirada dos mesmos foi praticamente igual nas variedades de laranjas avaliadas. 
Tabela 2. Análise quantitativa do teor de fenóis totais, quantificados usando o reagente de Folin-Ciocalteau, em extrato aquoso,etanólico e metanólico de albedo de laranja, variedades Pêra-Rio, Valência e Natal.

\begin{tabular}{lccc}
\hline & $\mu g$ Equivalente de ácido clorogênico por g de extrato \\
& \multicolumn{3}{c}{ liofilizado de albedo ${ }^{1}$} \\
\hline Extrato $^{1}$ & Pera-Rio & Valência & Natal \\
Aquoso & $540,3 \mathrm{~A}^{2}$ & $461,2 \mathrm{~A}$ & $418,6 \mathrm{~A}$ \\
Etanólico & $1.141,7 \mathrm{~B}$ & $678,1 \mathrm{~B}$ & $560,3 \mathrm{~B}$ \\
Metanólico & $1.188,6 \mathrm{~B}$ & $1.072,9 \mathrm{C}$ & $1.033,4 \mathrm{C}$ \\
\hline
\end{tabular}

${ }^{1}$ Extratos obtidos a partir da diluição de $200 \mathrm{mg}$ de extrato de albedo liofilizado em $2 \mathrm{~mL}$ de água destilada esterilizada.

${ }^{2}$ Médias de repetições seguidas da mesma letra na coluna dentro de cada tratamento, não diferem significativamente entre si pelo teste de Tukey a $5 \%$ de probabilidade.

Tabela 3. Análise quantitativa de fenóis totais usando o reagente de Folin-Ciocalteau no flavedo (com e sem sintoma de MPC) e albedo de laranja Pêra-Rio.

\begin{tabular}{lccr}
\hline \multicolumn{4}{c}{$\mu \mathrm{g}$ Equivalente de ácido clorogênico por g de extrato } \\
liofilizado de albedo
\end{tabular}

${ }^{1 / E x t r a t o s ~ o b t i d o s ~ a ~ p a r t i r ~ d a ~ d i l u i c ̧ a ̃ o ~ d e ~} 200 \mathrm{mg}$ de extratos de flavedo e de albedo liofilizados em $2 \mathrm{~mL}$ de água destilada.

${ }^{2 /}$ Médias de repetições seguidas da mesma letra na coluna dentro de cada tratamento, não diferem significativamente entre si pelo teste de Tukey a $5 \%$ de probabilidade.

${ }^{3 /}$ Mancha preta dos citros.

De acordo com a Tabela 3, foi observado que o acúmulo de compostos fenólicos no albedo (tecido resistente) foi maior, quando comparado com o flavedo (tecido suscetível) com sintomas de MPC ou assintomático. Este fato corrobora com as observações de Musumeci \& Oliveira (1975), nas quais os autores verificaram um maior acúmulo de fenóis em raízes de laranja azeda 
(Citrus aurantium-resistente), quando comparadas com laranja doce (Citrus sinensis-suscetível) inoculadas com Phytophthora citrophthora. Estas observações também corroboram com as de Mace (1963), nas quais o autor, relata um aumento no teor de fenóis em raízes de Musa acuminata variedade Gros Michel em relação a Fusarium oxysporum f. cubense. Em todos os trabalhos relacionados acima, ficou evidenciado que ocorre um maior acúmulo no teor de fenóis totais em tecidos resistentes, quando comparado com o teor de fenois totais em tecidos susceptíveis, fatos estes que validam os dados apresentados na Tabela 3. Khan et al. (1986) também observaram o acúmulo de fenólicos com características de fitoalexinas, no sítio de infecção em tecidos suscetíveis de Citrus cinensis (var. Valência tardia) e resistentes de Poncirus trifoliata (limão rugoso), induzidos pela aplicação de Fosetil -Al e elicitores (glucosamina e ácido araquidônico), em resposta a infecção por Phytophthora citrophthora, $P$. parasitica e $P$. citricola. Estes autores relataram que na composição do fenólicos totais, o ácido benzóico e derivados do ácido cinâmico foram os prováveis responsáveis pela toxicidade de extratos metanólicos de folhas e raízes do limão azedo, em relação aos patógenos avaliados.

Segundo Mace (1963), uma das razões possíveis para a resistência de certos tecidos àcolonização seria o rápido acúmulo de fenóis no sítio de colonização, o que acarretaria a morte das células no local, resultando no isolamento do patógeno, fato este comprovado através de estudo histológico comparativo entre tecidos de raízes de banana sadios e infectados com F. oxysporum f. cubense.

Foi observado que a colonização de $P$. citricarpa, em lesões do tipo mancha dura, nos frutos das variedades de laranja estudadas, fica restrita a alguns milímetros na região do albedo (Figura 3), imediatamente abaixo da lesão, fato este também relatado por Kotzé (1981) e Góes (1998). Esta constatação, de acordo com Cadena-Gomez \& Nicholson (1987), poderia estar 


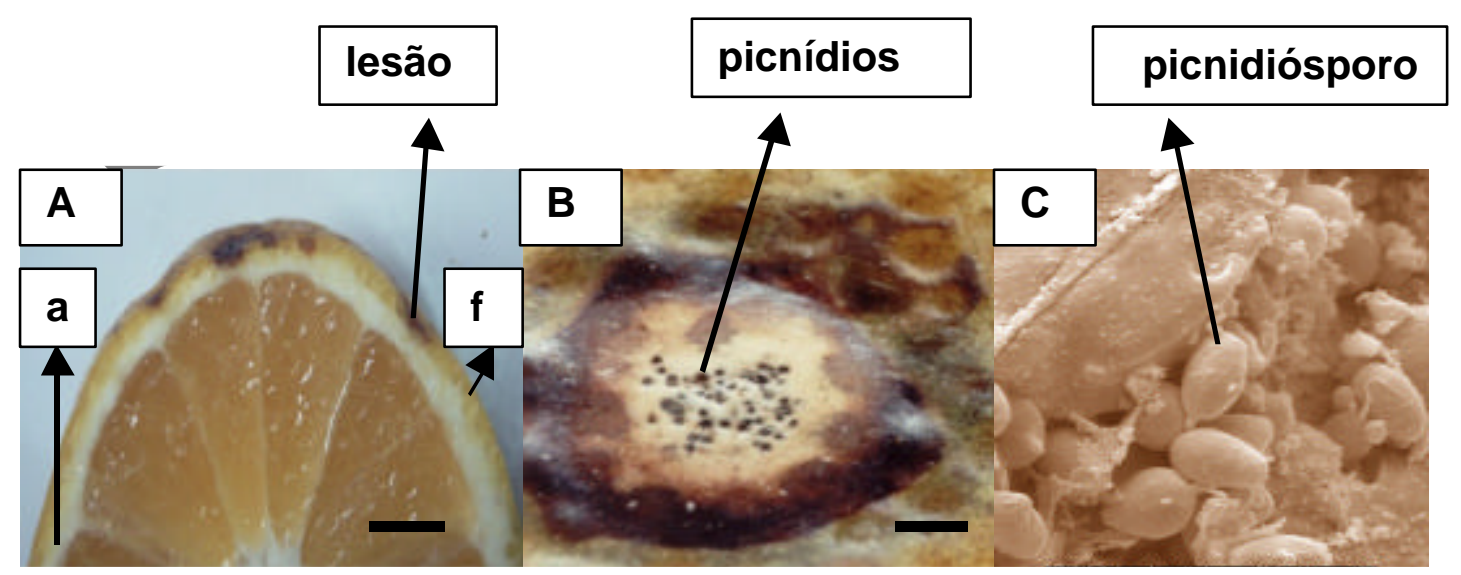

Figura 3 - A - Corte transversal em fruto de laranja Pêra-Rio com sintoma de MPC, do tipo mancha virulenta, destacando a restrição do patógeno $P$. citricarpa ao flavedo (f), casca ou epicarpo, permanecendo o albedo (a) ou mesocarpo intacto. B - Detalhe na lesão da presença de picnídios de $P$. citricarpa. C - Detalhe da presença de picnidióporos de $P$. citricarpa (x 1950). Barra 4 $\mathrm{mm}$. 
relacionada ao acúmulo de fenóis polimerizados no sítio de infecção, e seria considerada como uma primeira reação de defesa do hospedeiro ao ataque do patógeno (Marten \& Kneusel, 1988).

Estudos histoquímicos e ultraestruturais em folhas de pepino em resposta a Colletotrichum lagenarium, realizados por Sten et al. (1993), revelaram a presença de fenóis no sítio de infecção, o que reforça a suposição de que a restrição de $P$. citricarpa ao albedo pode ser devido ao acúmulo de compostos polimerizados como observado na região do albedo logo abaixo de lesões do tipo mancha dura e mancha virulenta (Figura 3). De acordo com Marten \& Kneusel (1988), como resposta secundária ao ataque teríamos à ativação de mecanismos de defesa mais específicos, tais como a síntese de fitoalexinas e proteínas relacionadas a patogênese (proteínas-RP).

\subsubsection{Detecção da atividade antifúngica dos extratos}

\subsubsection{Influência na germinação de picnidiósporos e formação de apressório}

De acordo com as Figuras 4 e 5, verificou-se que a concentração mais efetiva foi de $10 \mathrm{mg} \mathrm{mL}^{-1}$ (diluição de 1/10) para todos os extratos estudados. Estes dados corroboram com os obtidos por El-Tobshy \& Sinclair (1964), onde os autores utilizaram extratos aquosos de albedo (mesocarpo) isolado ou associado com o flavedo (epicarpo) de laranja. Ainda segundo os mesmos autores, o albedo isolado ou associado ao flavedo, foi efetivo no controle do crescimento in vitro de Phomosis citri.

Os resultados obtidos no presente estudo indicam a presença de substâncias fungitóxicas nos extratos de albedo testados. À medida em que se diluíram os extratos (aquoso, etanólico e metanólico) a percentagem de germinação aumentou, o que presumidamente se deve ao fato de que o princípio ativo presente nos extratos e responsável pela inibição da germinação 
de pícnidiósporos e formação de apressórios teve a sua concentração diminuída.

Foi observado que o extrato bruto de albedo, quando autoclavado (dados não mostrados) ou filtrado em filtro Millipore de $0,22 \mu \mathrm{m}$ diâmetro, não apresentou atividade antifúngica, o que leva a suposição de que o princípio ativo presente no albedo de laranja, trata-se de um composto ou um aglomerado de compostos de elevado massa molecular e termolábel.

De um modo geral, foi constatado (Figuras 4 e 5 ) que existe uma diferença de fungitoxidade entre os extratos de albedo testados, sendo maior para o extrato metanólico, intermediária para o etanólico e menor para o aquoso. De fato, esta observação é consistente com os relatos de Harborne (1969, 1989) e Ribéreau-Gayon (1972), nos quais os autores atestam que a extração com água está restrita a fenóis ligados a açúcares (fenóis glicosilados), os quais são mais hidrossolúveis do que os fenóis aglicônicos (não ligados a açúcares), o que limita a extração com água para apenas uma parte dos fenóis presentes no extrato, explicando assim os resultados apresentados na Tabela 2.

A partir dos dados da Figura 5, podemos supor que a formação de apressório é aparentemente mais sensível àação fungitóxica dos extratos, fato que pode ser atribuído a maior permeabilidade da parede celular àação destes compostos durante esta fase de crescimento do fungo (Hammerschmidt et al., 1976; Hammerschmidt \& Kuc, 1982; Howard, \& Ferrari, 1989).

A presença de compostos biologicamente ativos em extratos vegetais pode ser influenciada por vários fatores tais como método de extração, idade da planta, tempo de coleta do material e solventes utilizados na extração (Dey \& Harborne, 1989; Waterman \& Mole,1994). Desta forma, a reprodutibilidade de experimentos envolvendo o uso de extratos vegetais brutos é muito difícil (Amadioha, 2000; Qasem \& Abu-Blan, 1996, Quiroga et al., 2001;Tewari \& Nayak, 1991). Portanto, comparações com outros experimentos devem ser efetuadas com bastante critério. 


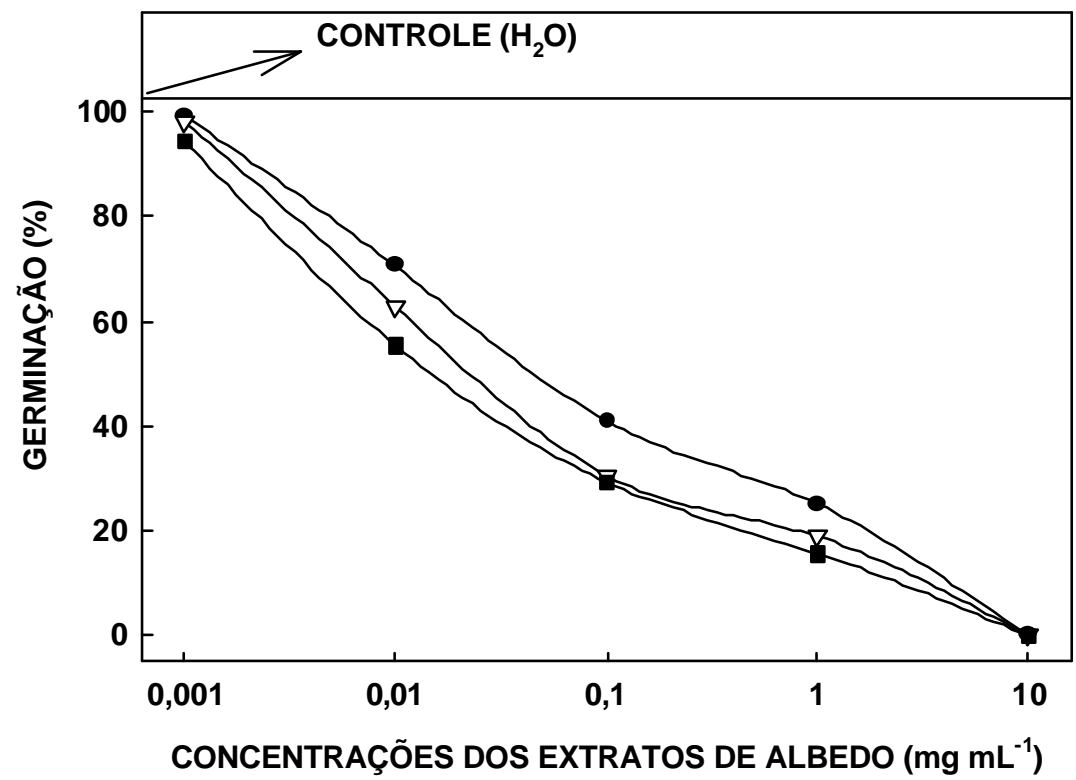

Figura 4 - Efeito de extratos (aquoso, etanólico, metanólico) de albedo de laranja PêraRio, na germinação de picnidiósporos de $P$. citricarpa. Os valores representam a média (seis repetições) dos dados percentuais observados, em relação ao total de 100 picnidiósporos, após $12 \mathrm{~h}$ de incubação à $26{ }^{\circ} \mathrm{C}$ em câmara de crescimento. As concentrações foram obtidas a partir de solução-estoque contendo $100 \mathrm{mg}$ de extrato de albedo liofilizado / $\mathrm{mL}$ de água destilada esterilizada. 


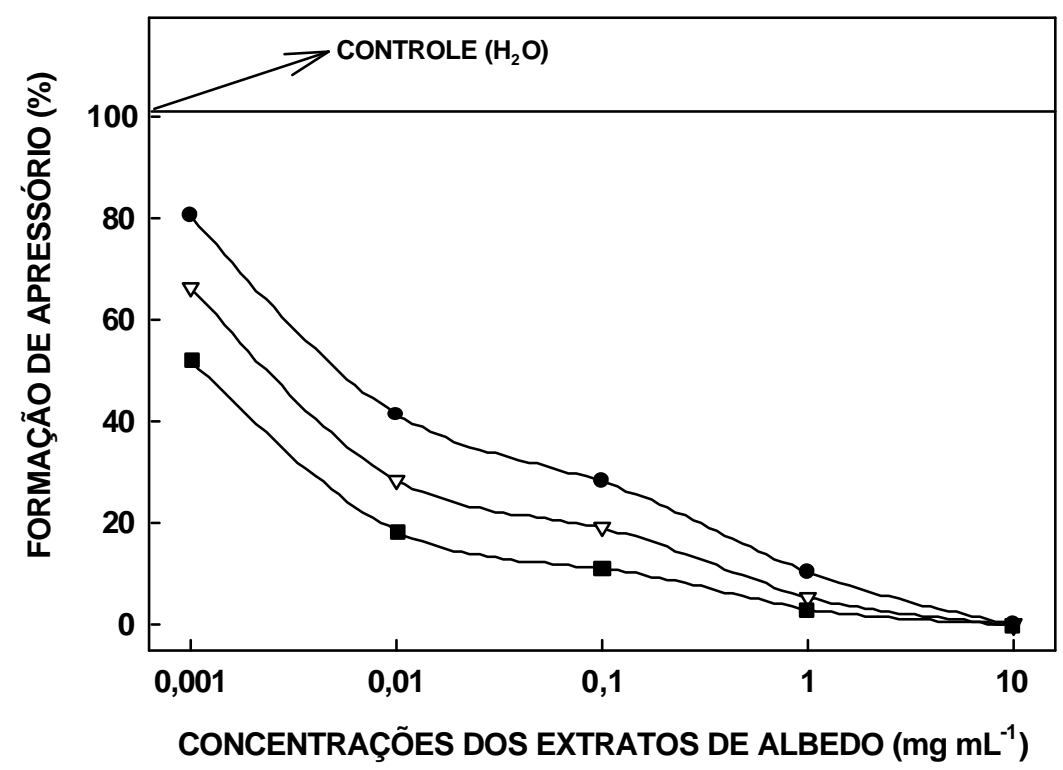

$$
\begin{aligned}
& \rightarrow \text { AQUOSO }=-8,3037 \cdot \operatorname{Ln}(X)+12,8 \quad R^{2}=0,93^{\star} \\
& \rightarrow-\text { ETANÓLICO }=-6,7489 \cdot \operatorname{Ln}(X)+8,22 R^{2}=0,87^{\star} \\
& \rightarrow-\text { METANÓLICO }=-5,168 \cdot \operatorname{Ln}(X)+4,94 R^{2}=0,81^{*}
\end{aligned}
$$

Figura 5 - Efeito de extratos (aquoso, etanólico, metanólico) de albedo de laranja PêraRio, na formação de apressórios de picnidiósporos de $P$. citricarpa. Os valores representam a média (seis repetições) dos dados percentuais observados, em relação ao total de 100 picnidiósporos, após $12 \mathrm{~h}$ de incubação ì $26{ }^{\circ} \mathrm{C}$ em câmara de crescimento. As concentrações foram obtidas a partir de solução-estoque contendo $100 \mathrm{mg}$ de extrato de albedo liofilizado / $\mathrm{mL}$ de água destilada esterilizada. Foram considerados como formados os apressórios de comprimento iqual ou superior ao tamanho do picnidiósporo. 


\subsubsection{Influência no crescimento micelial}

Os resultados apresentados na Figura 6 mostram à semelhança do item anterior, que a concentração de $10 \mathrm{mg} \mathrm{mL}^{-1}$ apresentou máxima percentagem de inibição (100\%), em relação às diluições testadas. Também foi observado que os extratos aquosos e etanólicos na concentração de 0,001 mg $\mathrm{mL}^{-1}$ (diluição de 1/100.000) estimularam o crescimento da colônia fúngica. Esta diferença na fungitoxidade dos extratos testados pode ser atribuída à diluição ou concentração do princípio ativo presente nos mesmos em relação aos solventes utilizados ou ainda pela presença de inibidores destes compostos nos extratos avaliados (Tewari \& Nayak, 1991; Qasem \& Abu-Blan, 1996, Amadioha, 2000).

Foi constatado que apenas a concentração de $10 \mathrm{mg} \mathrm{mL}^{-1}$ apresentou atividade fungicida, as demais apresentaram atividade fungistática (dados não mostrados). Este comportamento é bastante comum em extratos vegetais brutos e já foi observado por diversos autores (Quiroga et al., 2001; Catarino et al., 1990).

De acordo com Madingan et al. (2000), a maioria dos compostos considerada fungistáticos possui ação direta na síntese protéica, inibindo-a, quando presentes em alta concentração. Ainda segundos estes autores, estes compostos se ligariam aos ribossomos através de ligações fracas (não covalentes) e na medida em que a concentração dos mesmos diminui, estas ligações são quebradas permitindo, a síntese de proteínas. Desta foma, isto poderia presumidamente justificar o crescimento do fungo $G$. citricarpa, quando colocado em novo meio de cultura, sem a presença dos extratos testados. Porém, novos experimentos são necessários para comprovar esta possibilidade. Finalizando, outros fatores como a reatividade química, oxidação do extrato utilizado e a composição do meio (tipo de fonte de carbono) também podem influenciar experimentos desta natureza (Amadioha, 2000). 


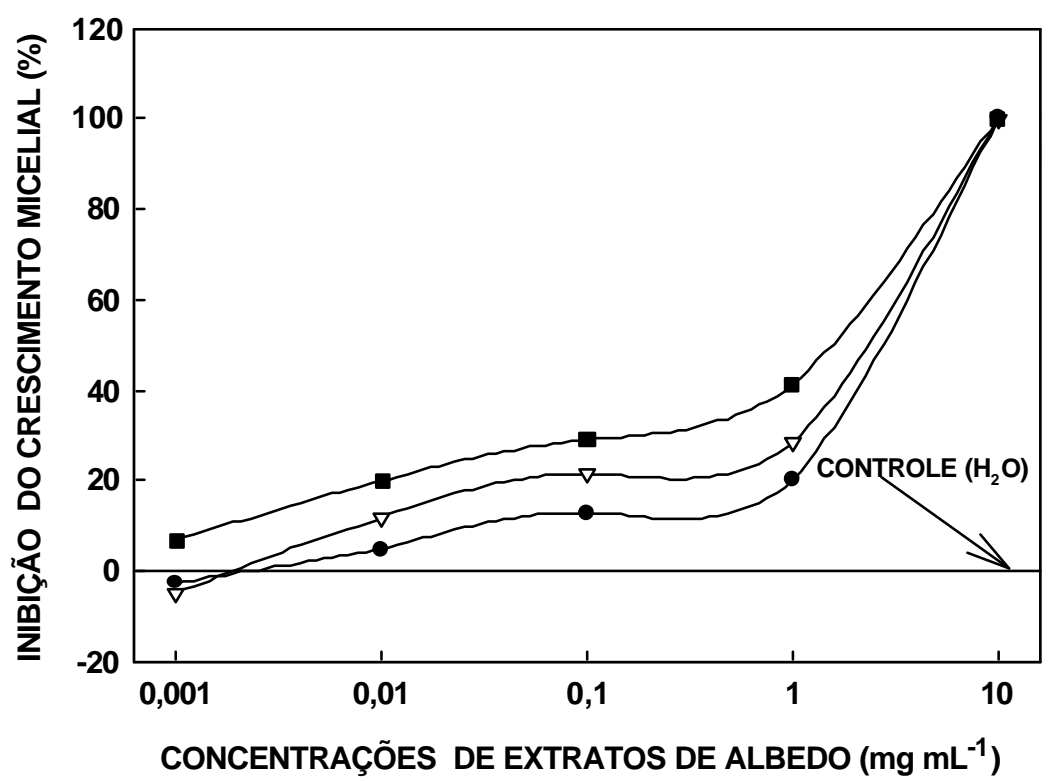

$\longrightarrow$ AQUOSO $=-8.049,1 X^{2}+1.764,6 X+4,029 R^{2}=0,98$ **

$\neg-$ ETANÓLICO $=-13.664 X^{2}+2.285,8 X+8,049 \quad R^{2}=0,95^{*}$

$\rightarrow-$ METANÓLICO $=-18.733 X^{2}+2.702,5 X+17,069 R^{2}=0,96$ *

Figura 6 - Percentagem de inibição do crescimento micelial de $P$. citricarpa aos 15 dias, por extrato (aquoso, etanólico e metanólico) liofilizado de albedo de laranja Pêra-Rio. Os valores representam a média (seis repetições) de 4 medidas do diâmetro da colônia por repetição. $O$ fungo foi crescido a $26{ }^{\circ} \mathrm{C}$, sob luz fluorescente, com alternância de luminosidade (12 h claro/ 12 $\mathrm{h}$ escuro). As concentrações dos extratos foram obtidas de solução-estoque contendo $100 \mathrm{mg}$ de extrato de albedo liofilizado / $\mathrm{mL}$ de água destilada esterilizada. 


\subsubsection{Influência na formação de picnídios em folhas autoclavadas}

Foi observado que os extratos de albedo, na concentração de 100 $\mathrm{mg} \mathrm{mL}^{-1}$ ( $0 \%$ ou seja, sem diluição) foram capazes de inibir a formação in vitro de picnídios em folhas autoclavadas de limão siciliano, podendo o efeito dos

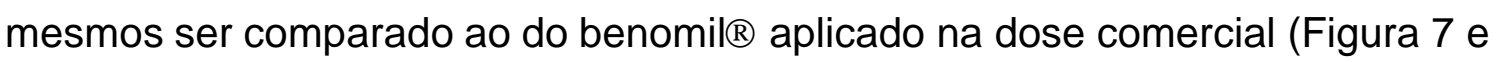
Tabela 4). O uso de folhas autoclavadas é um dos principais métodos para a obtenção de picnidiósporos in vitro. Esta técnica foi desenvolvida para $P$. citricarpa por Glienke (1995). O benomil foi utilizado como parâmetro de controle positivo, visto que, o controle de $P$. citricarpa no campo é baseado principalmente na utilização de fungicidas protetores ou sistêmicos, aplicados isoladamente, associados ou combinados com óleo mineral ou vegetal.

Tabela 4. Efeito da concentração de extrato de albedo de Citrus sinensis (var. Pêra-Rio), benomil ${ }^{\circledR}$ e água destilada esterilizada na formação in vitro de picnídios de $P$. citricarpa, em folhas autocladas de limão Siciliano, após 18 dias a $26^{\circ} \mathrm{C}$ em câmara de crescimento com alternância de luminosidade ( $12 \mathrm{~h}$ claro e $12 \mathrm{~h}$ escuro, luz fluorescente).

\begin{tabular}{|c|c|c|c|}
\hline \multicolumn{2}{|c|}{ Tratamento } & Número ${ }^{1}$ de picnídios formados & Diluição \\
\hline $\begin{array}{l}\text { Benomil }^{2} \\
\mathrm{H}_{2} \mathrm{O} \text { destilada }\end{array}$ & & \multicolumn{2}{|l|}{0} \\
\hline \multirow{5}{*}{$\begin{array}{r}\text { Extrato de } \\
\text { albedo }\end{array}$} & $1 \mathrm{mg} \mathrm{mL}^{-1}$ & $164 \pm 10,2$ & $100 \%$ \\
\hline & $1,3 \mathrm{mg} \mathrm{mL}^{-1}$ & $98 \pm 4,1$ & $75 \%$ \\
\hline & $2 \mathrm{mg} \mathrm{mL}^{-1}$ & $42 \pm 5,8$ & $50 \%$ \\
\hline & $4 \mathrm{mg} \mathrm{mL}^{-1}$ & $10 \pm 2,3$ & $25 \%$ \\
\hline & $100 \mathrm{mg} \mathrm{mL}^{-1}$ & 0 & 0 (não diluído) \\
\hline
\end{tabular}




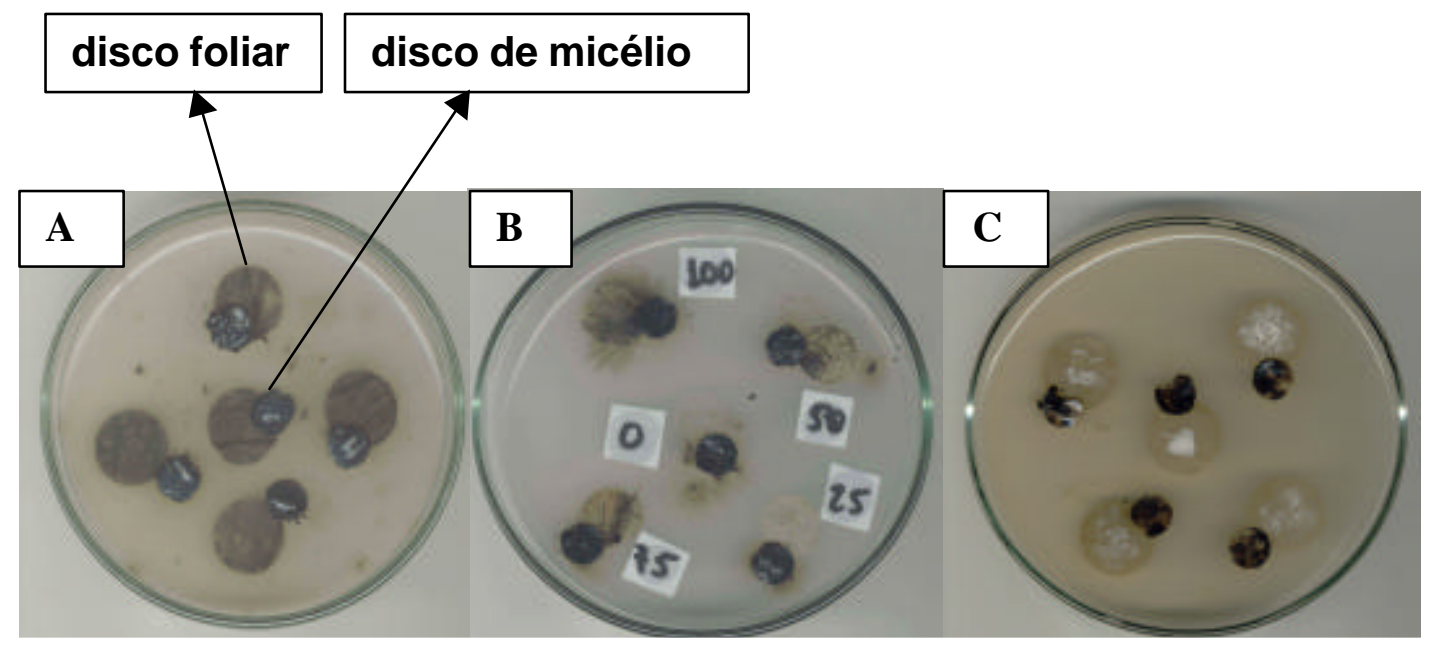

Figura 7 - Efeito de água destilada esterilizada (A), da concentração de albedo laranja Pêra-Rio 100 (0\%); 4 (25\%); 2 (50\%); 1,3 $(75 \%)$ e $1(100 \%) \mathrm{mg} \mathrm{mL}^{-1}$ em água destilada esterilizada, $\mathrm{v} / \mathrm{v}(\mathrm{B})$ e benomil $(\mathrm{C})\left(0,35 \mathrm{~g}\right.$ p.a. $\left.\mathrm{L}^{-1}\right)$ na formação in vitro de picninídios de Phyllosticta citricarpa (teleomorfo: Guignardia citricarpa) em folhas de limão Siciliano autoclavadas. 
A possibilidade da utilização de componentes biologicamente ativos do albedo de laranja no controle do patógeno é uma excelente opção, visto existir uma tendência mundial nos últimos anos, em restringir o uso de fungicidas em pós-colheita e este fato, tem levado à procura de métodos biológicos e alternativos de controle de doenças em plantas (Benato, 1999). De fato o uso de extratos vegetais, fungicidas não seletivos, antioxidantes e outros métodos de controle alternativos têm sido relatados (Ribeiro \& Bedendo, 1999; Franco \& Bettiol, 2000; Kariba et al., 2001; Stangarlin et al., 1999), entretanto não foi encontrado nenhum trabalho, até o momento, fazendo menção do emprego de extratos do albedo de laranja no controle de $G$. citricarpa em citros. Desta forma, comparações entre a metodologia empregada neste ensaio com relatos de outros trabalhos existentes na literatura, fica impossibilitada.

\subsubsection{Análise cromatográfica dos extratos e detecção da atividade antifúngica}

Com base no espectro de absorção em ultra violeta (U.V.) (Figuras 8 e 9) das amostras dos extratos $\mathrm{AgH}_{2} \mathrm{O}, \mathrm{EtOH}$ e $\mathrm{MeOH}$, submetidos a TLC, os dados revelaram três espectros muitos próximos e com dois picos de absorbância distintos. Isto pode ser comprovado pelos valores de $\mathrm{Rf}$ apresentados pelos eluentes das amostras (Tabela 5).

Tabela 5. Componentes do albedo de laranja Pêra-Rio separados por cromatografia de camada delgada ${ }^{1}$

\begin{tabular}{|c|c|c|c|c|}
\hline Eluente & $\mathrm{Rf}$ & Luz visível & $\begin{array}{l}\text { Cor desenvolvida } \\
\text { Luz U.V. (curto) }\end{array}$ & Luz U.V. (longo) \\
\hline Água & 0,55 & rosa escuro & marrom escuro & azul-esverdeado \\
\hline Etanol & 0,55 & rosa escuro & marrom escuro & azul-esverdeado \\
\hline Metanol & 0,55 & rosa escuro & marrom escuro & azul-esverdeado \\
\hline
\end{tabular}


De acordo com Ribéreau-Gayon (1972), picos com absorção entre 270 e $280 \mathrm{~nm}$ no UV, pode ser um indicativo da presença de fenóis simples, entretanto, de acordo com a literatura (Harborne, 1964; Dey \& Harborne, 1989; Dyer, 1965; Silverstein \& Bassler, 1967), uma gama enorme de compostos fenólicos na forma livre pode absorver nesta faixa. Desta forma, amostras de extratos brutos de albedo foram submetidas a uma análise mais detalhada, com o auxílio do Prof. Dr. Edson Rodrigues Filho, no Laboratório de Espectrometria de Massas (LEM-DQ) - Departamento de Química da Universidade Federal de São Carlos (UFSCar), onde foram submetidos à Cromatografia Líquida de Alta Resolução (HPLC), Ressonância Magnética Nuclear $\left(\mathrm{RMN}-{ }^{13} \mathrm{C}\right)$ e espectrometria de massas.

Deste modo, a partir do pó seco dos extratos brutos de albedo, foram extraídas, com os solventes $\mathrm{CH}_{2} \mathrm{Cl}_{2}: \mathrm{MeOH} 1: 1, \mathrm{MeOH} 100 \%, \mathrm{MeOH}: \mathrm{H}_{2} \mathrm{O}$ 9:1 (conforme o fluxograma apresentado no apêndice 2) frações, que tiveram atividade biológica comprovada (Magnani et al., 2002) contra picnidiósporos de e $P$. citricarpa, avaliados em lâminas de poliestireno nas concentrações de 5 e $10 \mathrm{mg} \mathrm{mL}^{-1}$. Destas frações foi identificado o flavonóide glicosilado naringina (Magnani et al., 2002), cujo espectro é apresentado no apêndice 3 . Este flavonóide foi identificado por $\mathrm{RMN}-{ }^{13} \mathrm{C}$ e espectrometria de massas, no modo de ionização Electrospray positivo (ES+), de onde a naringina, foi detectada no pico base em $\mathrm{m} / \mathrm{z} 581\left([\mathrm{M}+\mathrm{H}]^{+}\right)$, com uma massa molecular de 580 u.m.a. $\left(\mathrm{C}_{27} \mathrm{H}_{32} \mathrm{O}_{14}\right)$. No espectro de ESI-CAD, detectou-se o íon $\mathrm{m} / \mathrm{z} 419$ como pico base relativo àperda de $162 \mathrm{Da}$ (eliminação interna de glicose), característico da naringina e observou-se, ainda, o íon de $\mathrm{m} / \mathrm{z} 273$ relativo a perda da raminose terminal. 


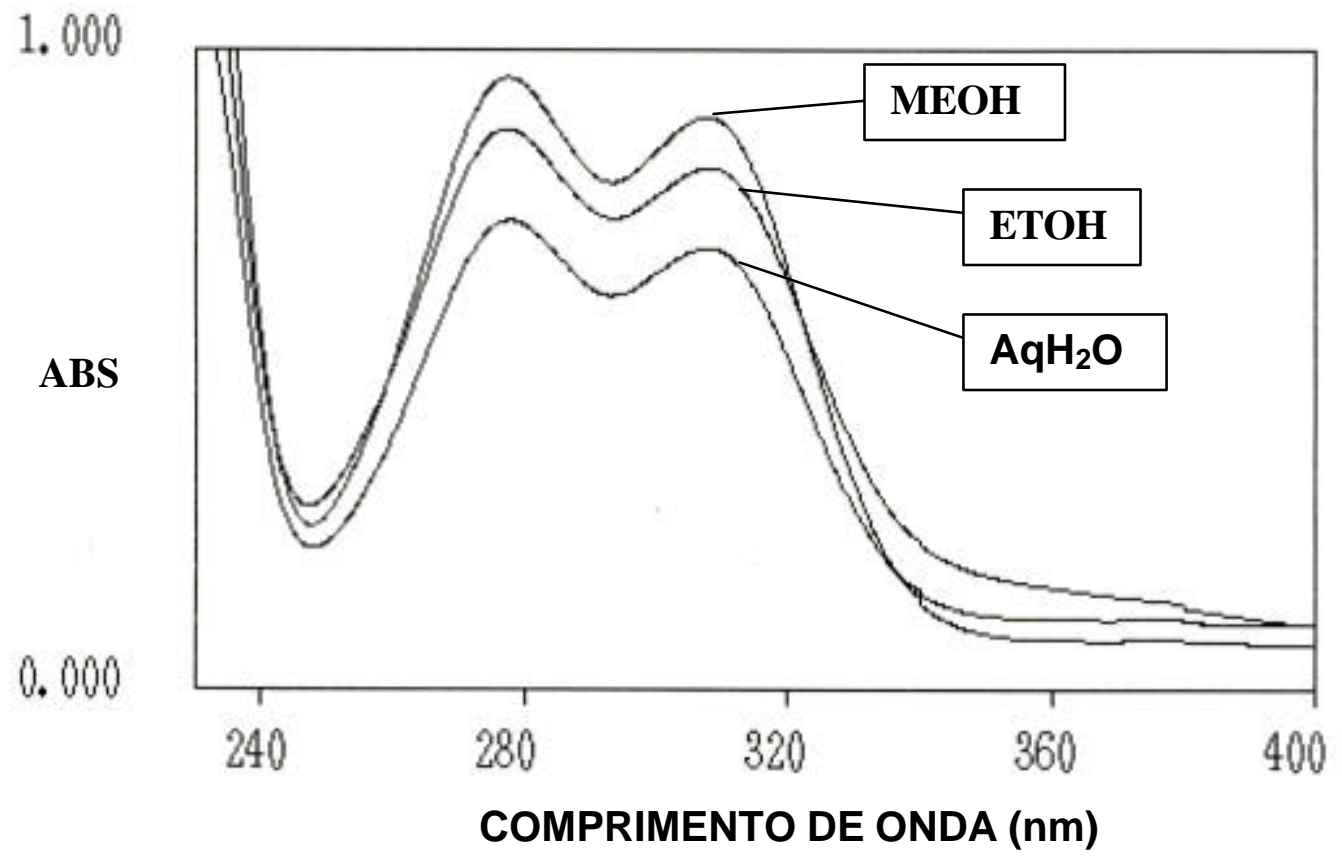

Figura 8 - Espéctro ultra violeta de absorção dos eluentes de extratos (200 $\left.\mathrm{mg} \mathrm{mL}^{-1} \quad \mathrm{H}_{2} \mathrm{O}\right)$ liofilizados metanólicos $(\mathrm{MeOH})$, etanólicos (EtOH) e aquosos $\left(\mathrm{AqH}_{2} \mathrm{O}\right)$ de albedo de laranja Pêra-Rio em placas de sílica gel $\left(\mathrm{SiO}_{2} \times \mathrm{H}_{2} \mathrm{O} 20 ; 20 \mathrm{~cm}\right.$; G $60 \mathrm{~F}_{250 \mathrm{~nm}}$ (Whatman) com indicador de luminescência através de cromatrografia de camada delgada (fase móvel: butanol, ácido acético, água; $4: 1: 1 ; \mathrm{v} / \mathrm{v} / \mathrm{v})$. Comprimento de onda máximo para $\mathrm{MeOH}=308,2$ e 278,7; $\mathrm{EtOH}=306,3$ e 276,9; $\mathrm{AqH}_{2} \mathrm{O}=307,9$ e 277,6. ABS = absorbância. 


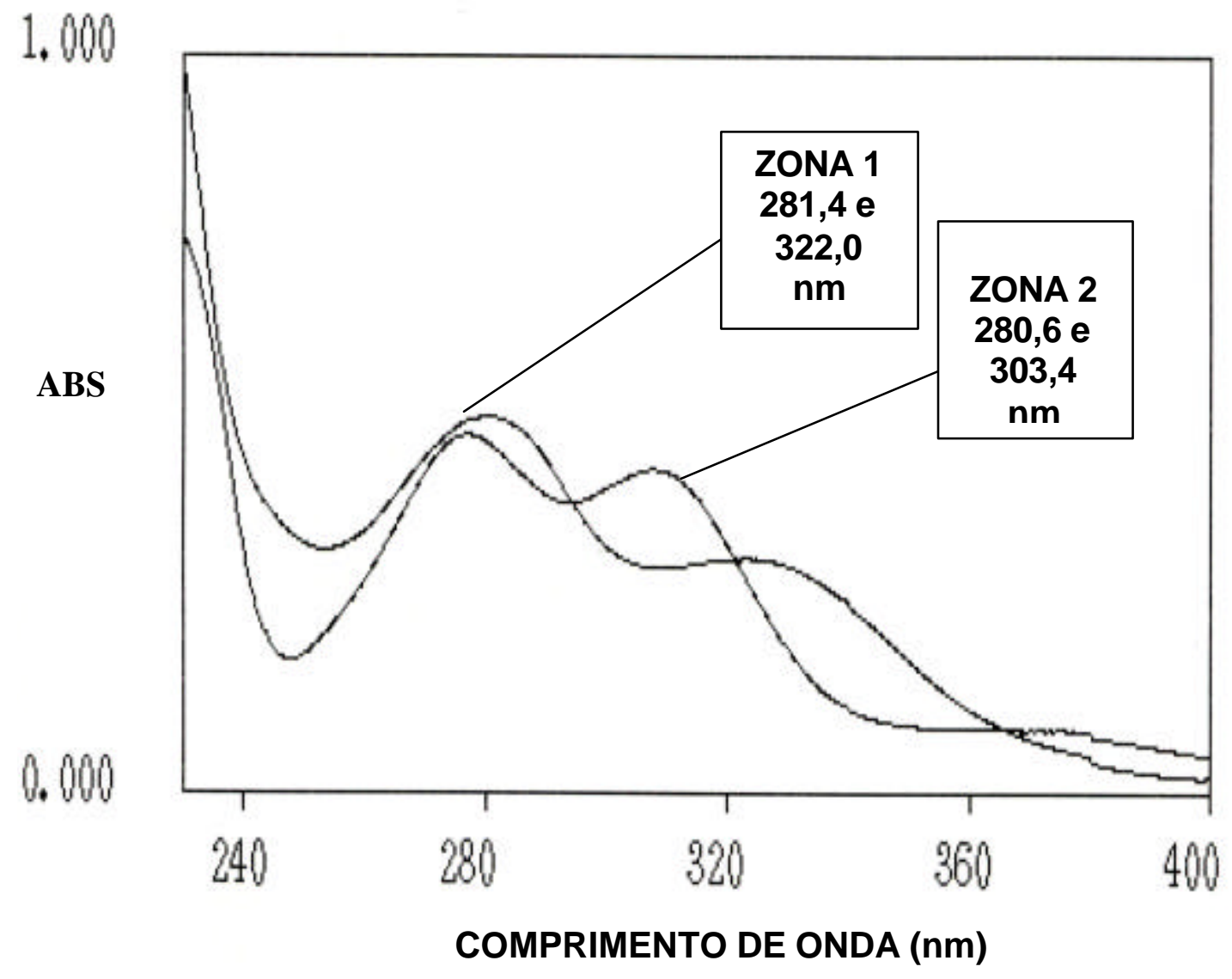

Figura 9 - Espéctro ultra violeta de absorção de eluentes das zonas de inibição 1 e 2 obtidas a partir da bioautografia com penicillium digitatum em placas de sílica gel $\left(\mathrm{SiO}_{2} \times \mathrm{h}_{2} \mathrm{O}\right.$ 20; $20 \mathrm{~cm} ; \mathrm{g} 60 \mathrm{f}_{254} \mathrm{~nm}$ (whatman) com indicador de luminescência em cromatrografia de camada delgada.fase móvel butanol / ácido acético / água (4:1:1, $\mathrm{v} / \mathrm{v} / \mathrm{v})$. os eluentes foram visualizados sob luz ultra violeta (365 e $254 \mathrm{~nm}$ ) antes da bioautografia. 
Este flavonóide foi confrontado com o extrato bruto de albedo em lâminas de poliestireno, adotando-se o mesmo procedimento descrito no ítem 3.2.5.1., e não foi capaz de inibir in vitro a germinação de picnidiósporos ou a formação de apressórios de $P$. citricarpa, o que pode ser um indício da presença de outros princípios com atividade biológica, que podem estar atuando isoladamente ou combinados, no albedo das variedades avaliadas. De fato a literatura nos mostra (Widmer \& Montanari (1994) que flavonóides glicosilados, tais com a naringina e hesperidina, apesar de presentes em grandes quantidades no albedo (Horowitz,1961; Sinclair, 1984) não são reconhecidos pela ação antimicrobiana ou antiviral e sim os flavonóides metoxilados (Kaul et al., 1985; Widmer \& Montanari, 1994).

Desta forma, novos experimentos devem ser realizados no intuito de identificar e isolar, componente do albedo, exibindo atividade inibitória em relação a P.citricarpa e quem sabe no futuro, possibilitar o seu emprego no campo como um biofungicida comercial para uso tanto em pré, quanto em póscolheita.

\subsection{Conclusões}

Os extratos de albedo de laranja testados, dependendo da concentração testada, exibem ação fungistática ou fungicida in vitro, podendo inibir a germinação, a formação de apressório e o crescimento micelial de Phyllosticta citricarpa. 


\section{Guignardia citricarpa EM LARANJA: BION ${ }^{\circledR}$, ÁCIDO SALICÍLICO E Saccharomyces cereviseae NÃO CONTROLAM O PATÓGENO}

\section{Resumo}

A doença "Mancha Preta dos Citros" afeta principalmente frutos, tornando-os impróprios para o mercado. O controle do patógeno (Guignardia citricarpa) baseia-se principalmente na utilização de diferentes combinações de fungicidas protetores e sistêmicos. Desta forma, devido à problemas relacionados com a toxicidade ao homem, surgimento de isolados resistentes e efeitos danosos ao ambiente, medidas alternativas de controle devem ser encontradas. Portanto, a indução de resistência em citros a Phyllosticta citricarpa (fase teleomórfica: Guignardia citricarpa) foi avaliada em condições de pré e pós-colheita. Nos ensaios de pós-colheita, frutos verdes assintomáticos ou sintomáticos de laranja Pêra Rio foram colhidos (município de Conchal-SP) e submetidos aos tratamentos com Saccharomyces cereviseae (0 a $25 \mathrm{mg} \mathrm{mL}^{-1}$ ), Bion $^{\circledR}$ ( 0 a 80 g p.a. $100 \mathrm{~L}^{-1}$ ) ou ácido salicílico ( 0 a $2 \mathrm{mM}$ ), com tempo de exposição para cada indutor de $20 \mathrm{~min}, 3,6$ ou $10 \mathrm{~h}$. O controle foi representado por frutos tratados com água. Para acelerar o aparecimento dos sintomas, os frutos foram tratados com Ethrel $\left(10 \mathrm{~mL} \mathrm{~L}^{-1}\right.$ por 20 min aplicado 24, 48 e $72 \mathrm{~h}$ antes ou depois dos indutores). Em pré colheita mudas de limão Siciliano (Citrus limonia) sadias foram inoculadas naturalmente com $G$. citricarpa e tratadas com Bion ( 0 a 80 g p.a. $100 \mathrm{~L}^{-1}$ ) ou Saccharomyces 
cereviseae ( 0 a $30 \mathrm{~g} \mathrm{~mL}^{-1}$ ). Estas foram levadas semanalmente a campo, e dispostas sob a copa de plantas infectadas com G. citricarpa, onde após seis meses avaliou-se o número de lesões surgidas nas folhas, após o período de latência do fungo. Com base nos resultados, os indutores avaliados não inibiram o aparecimento de lesões nos frutos em pós-colheita e nas folhas em pré-colheita. As possíveis razões para o insucesso dos indutores testados são discutidas no texto.

\section{Summary}

\section{Guignardia citricarpa in post-harvest of orange: Bion, salicylic acid and Saccharomyces cereviseae do not control the pathogen}

Black spot is an important citrus disease and diseased fruits become unacceptable for the fresh fruit market. The control of the pathogen (Guignardia citricarpa) is carried out by using different combinations of systemic and protectant fungicides. Because of problems related to fungicide toxicity, development of fungicide resistance by the pathogen, and potential harmful effects on the environment and human health, new alternative strategies for controlmust been found. Therefore, the induced resistance in citrus was evaluated against $P$. citricarpa at pre and posthavest conditions. For the experiments at postharvest, immature orange fruits with or without black spot symptoms were harvest (Conchal-SP) and treated with Saccharomyces cereviseae ( 0 to $\left.25 \mathrm{mg} \mathrm{mL}^{-1}\right)$, Bion ${ }^{\circ}\left(0\right.$ to $80 \mathrm{~g}$ i.a. $100 \mathrm{~L}^{-1}$ ) or salicylic acid ( 0 to $2 \mathrm{mM}$ ) during $20 \mathrm{~min}, 3,6$ or $10 \mathrm{~h}$. The control was represent by water-treated fruits. Ethrel ( $10 \mathrm{~mL}^{-1}$ for $20 \mathrm{~min}$ ) was applied 24,48 and $72 \mathrm{~h}$ before or after the 
inducers to speed the development of the symptoms on fruits. At preharvest conditions healthy plants of 'Siciliano' lemon were naturally inoculated with $G$. citricarpa and treated with Bion $®\left(0\right.$ to $80 \mathrm{~g}$ i.a. $\left.100 \mathrm{~mL}^{-1}\right)$ or Saccharomyces cereviseae $\left(0\right.$ to $\left.30 \mathrm{mg} \mathrm{mL}^{-1}\right)$. The plants were taken to the field weekly and placed under foliage of $G$. citricarpa infected citrus plants. After six months, the lemon leaves were evaluated the for the development of lesions that had formed. The results showed that the inducers tested did not inhibit the development of new lesions in the fruits at postharvest and in the leaves at preharvest. The possible reasons to the unsuccessfulness of the inducers tested are discussed. 


\subsection{Introdução}

A mancha preta dos citros (MPC), afeta folhas, ramos e, principalmente, frutos de laranjeiras doces, limoeiros verdadeiros, pomeleiros, algumas tangerineiras e vários híbridos (Robbs, 1990). A doença foi identificada pela primeira vez no Brasil em 1937, porém só foi observada em pomares comerciais a partir de 1980. A doença tem como agente causal o fungo Guignardia citricarpa (fase anamórfica: Phyllosticta citricarpa). Essa doença provoca lesões (manchas) que ficam restritas àcasca dos frutos prejudicando a sua aparência e dificultando a comercialização de frutos frescos no mercado interno e externo (Góes et al., 1990, 1998). A suscetibilidade do fruto ao fungo ocorre até cinco meses após a queda das pétalas das flores (Kotzé, 1981, 1996).

O emprego de fungicidas é o principal método de controle utilizado, tanto no Brasil, quanto em outros países, quando a produção destinase ao consumo de frutas, frescas (Góes, 1998; Kotzé, 1996). A utilização indiscriminada de fungicidas, já propiciou a seleção de isolados resistentes ao benomil no Brasil (Ghini \& Kimati, 2000) e na África do Sul (Herbert \& Grech, 1985).

Segundo Pascholati (1998), as plantas possuem diferentes mecanismos estruturais e bioquímicos que podem contribuir para sua a resistência contra fitopatógenos, sendo os mecanismos de resistência determinados geneticamente e a sua efetividade dependente da expressão destes em momentos adequados, magnitude adequada e em uma seqüência lógica, que deve ocorrer após o contato do patógeno com o hospedeiro.

A resistência induzida, também denominada de indução de proteção, imunidade adquirida ou resistência sistêmica adquirida, envolve a ativação dos mecanismos latentes de resistência de uma planta (Hammerschmidt \& Dann, 1997). A ativação pode ser obtida pelo tratamento com agentes bióticos, por exemplo, microrganismos viáveis ou inativados 
(Stangarlin \& Pascholati, 1994) ou abióticos, como por exemplo, ácido salicílico (Cohen, 1996, Hammerschmidt \& Dann, 1997), ácido aminobutírico (Cohen, 1996) e Bion ${ }^{\circledR}$ (Cole, 1999).

Este tipo de proteção induzida é dependente do intervalo de tempo que ocorre entre o tratamento com o indutor e a inoculação do patógeno. Assim, essa dependência indica que mudanças específicas no metabolismo da planta, que envolvem a síntese e/ou acúmulo de substâncias, são importantes no fenômeno da resistência induzida (Pascholati \& Leite, 1995).

Diante do exposto, o presente trabalho foi desenvolvido com o objetivo de se verificar o potencial de indutores abióticos (Bion e ácido salicílico) e bióticos (Saccharomyces cerevisiae) em induzir resistência em frutos de laranja (Citrus sinensis, variedade Pêra-Rio) a Phyllosticta citricarpa, em póscolheita.

\subsection{Material e métodos}

\subsubsection{Indução de resistência em pós-colheita}

Os experimentos foram conduzidos no Laboratório de Fisiologia e Bioquímica Fitopatológica do Setor de Fitopatologia do Departamento de Entomologia, Fitopatologia e Zoologia da ESALQ/USP, durante os meses de setembro a novembro dos anos de 2000 e 2001, utilizando-se frutos infectados naturalmente, os quais foram colhidos em plantios comerciais no município de Conchal (Fazenda Bela Vista) no Estado de São Paulo.

Nesta etapa, frutos verdes assintomáticos e sintomáticos de laranja Pêra Rio foram colhidos e submetidos aos tratamentos com Saccharomyces cereviseae "Fermento biológico fresco Fleishmann" (0 a 25 mg

$\mathrm{mL}^{-1}$ ), Bion ${ }^{\circledR} 500 \mathrm{GW}$ (0 a 80 g p.a. $100 \mathrm{~L}^{-1}$, Syngenta) ou ácido salicílico (0 a 2 $\mathrm{mM}$, Riedel-deHaën), com tempo de exposição para cada indutor de $20 \mathrm{~min}, 3$, 6 ou $10 \mathrm{~h}$. O controle foi representado por frutos tratados com água. Para 
acelerar o aparecimento dos sintomas, os frutos foram tratados com Ethre ${ }^{\circledR}$ (10 $\mathrm{mL} \mathrm{L}^{-1}$ por 20 min aplicado 24, 48 e $72 \mathrm{~h}$ antes ou depois dos indutores). Após sete dias, avaliou-se o número de lesões surgidas nos frutos após os tratamentos.

\subsubsection{Indução de resistência em pré colheita}

Os ensaios foram conduzidos no campo experimental do Departamento de Entomologia, Fitopatologia e Zoologia da ESALQ/USP, e na Fazenda Bela Vista, no município de Conchal, Estado de São Paulo, no período de outubro de 2001 a março de 2002.

Nesta fase experimental, duzentas mudas sadias de limão Siciliano (Citrus limonia) com oito meses de idade, enxertadas em Trifoliata, cedidas pela Fundecitrus (Araraquara-SP), foram transplantadas para vasos de $25 \mathrm{~kg}$ de capacidade contendo uma mistura, previamente autoclavada, de areia de rio, solo de encosta classificado como latossolo vermelho-amarelo distrófico (Professor Godofredo Vitti, comunicação pessoal, Departamento de Nutrição de Plantas, ESALQ/USP) e torta de filtro $(4: 2: 1, \mathrm{v} / \mathrm{v} / \mathrm{v})$. As mudas foram agrupadas em dois lotes (LT1, LT2) de cem mudas cada. Posteriormente, cada lote de cem mudas foi subdividido em lotes de quatro lotes de 25 mudas cada. Em cada lote de cem mudas, foi realizada uma poda, deixando-se um ramo principal e três ramos secundários. Dentro de cada lote de cem mudas, 25 mudas foram pulverizadas, durante três dias consecutivos, com Bion® na dose de 0 a $80 \mathrm{~g}$ p.a. $100 \mathrm{~L}^{-1}$ para LT1 e $S$. cereviseae na dose de 0 a $30 \mathrm{~g} \mathrm{~mL}^{-1}$ para LT2. Após cada pulverização as mudas foram levadas a campo (Fazenda Bela Vista, Conchal-SP) semanalmente, em lotes de 25. No campo estas foram distribuídas sob a copa de plantas adultas (seis anos de idade) de laranja Pêra-Rio, enxertadas em limão cravo (Citrus reticulata) infectadas com G. citricarpa (folhas) e $P$. citricarpa (frutos). Em cada lote semanal de 25 plantas, cinco mudas dentro de cada tratamento foram pulverizadas com água e utilizadas 
como controle. Os lotes LT1 e LT2 permaneceram no campo, conforme descrito acima, durante um período de seis meses (outubro de 2001 a março de 2002). Após este período, as mudas foram levadas para o campo experimental do Setor de Fitopatologia da ESALQ em Piracicaba para avaliação.

Durante o período de permanência das mudas no campo, foi realizado um levantamento climatológico semanal e da dispersão aérea dos ascósporos na área (Engenheiro Agrônomo Mário Moraes, comunicação pessoal, Casa da Agricultura, Secretaria de Agricultura de Conchal-SP).

A incidência da MPC foi calculada pela seguinte fórmula: \% Incidência $=\left(N^{\circ}\right.$ de folhas com lesões $/ N$ total de folhas contadas $) \times 100, a$ partir de um total de 60 folhas escolhidas ao acaso dentro de cada tratamento. Estas avaliações foram feitas mensalmente de outubro de 2001 a setembro de 2002. A severidade da doença foi avaliada a partir de uma escala diagramática de acordo com a Figura 10 (Noronha, 2003) e atribuíram-se notas de 1 a 5 com base na área foliar doente.
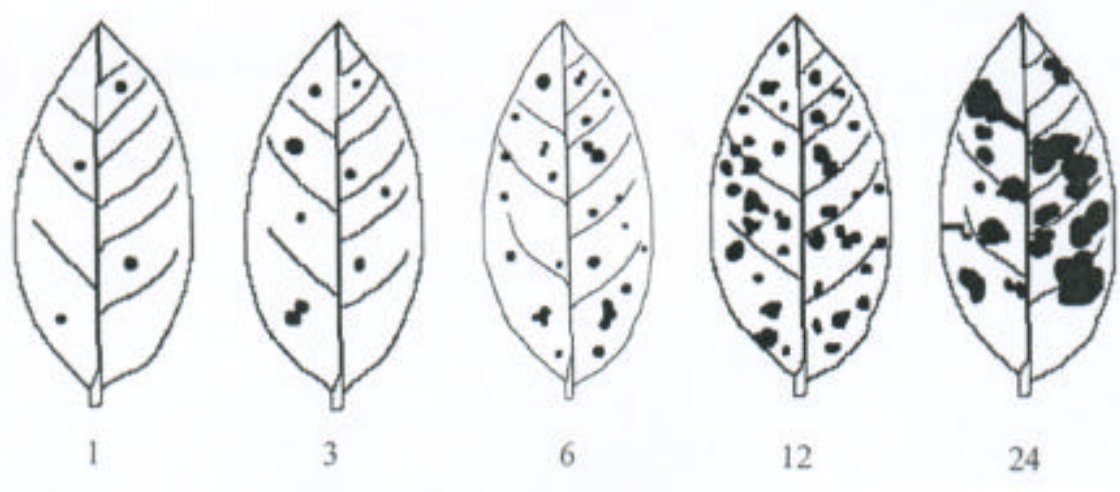

Figura 10 - Escala diagramática para avaliação da mancha preta dos citros (MPC) causada por Guignardia citricarpa em folhas de limão Siciliano (Citrus limonia) com cinco níveis de severidade da doença. (Noronha, 2003). 


\title{
4.2.3 Influência dos indutores na germinação de conídios e formação de apressório
}

\author{
O fungo G. citricarpa (forma anamórfica: $P$. citricarpa - isolado
} IAC-13/96), cedido gentilmente pelo pesquisador Carlos Aguilar-Vildoso (Centro de Citricultura Sylvio Moreira-IAC, Cordeirópolis-SP) foi isolado de frutos sintomáticos e posteriormente crescido em BDA (Oxoid) durante 20 dias, a $25^{\circ} \mathrm{C}$, sob fotoperíodo de $12 \mathrm{~h}$ (Glienke, 1995). Após este período, 100 discos (2 $\mathrm{cm}$ diâmetro) de folhas de limão Siciliano, foram colocados em um recipiente de vidro juntamente com $200 \mathrm{~mL}$ de água e autoclavados (20 min a $120{ }^{\circ} \mathrm{C}$ ) e colocados em seguida em placas de Petri com meio ágar-água ( $3 \% \mathrm{p} / \mathrm{v})$, sendo 5 fragmentos por placa. Logo após, nos pontos adjacentes aos fragmentos das folhas, foram colocados discos de micélio ( $1 \mathrm{~cm}$ diâmetro.), oriundos das placas com BDA, citadas anteriormente. As placas foram incubadas, em câmara de crescimento a $25^{\circ} \mathrm{C}$, também sob fotoperíodo de $12 \mathrm{~h}$ (luz fluorescente) (Glienke, 1995). Ao final de 14 dias, observou-se a presença de picnídios na superfície das folhas. A matriz gelatinosa presente no ostíolo do picnídio foi retirada com auxílio de um alfinete entomológico sob microscópio estereoscópico (aumento de 200 x) e utilizada para o preparo das suspensões de conídios $\left(2 \times 10^{4}\right.$ conídios $\left.\mathrm{mL}^{-1}\right)$, quantificados em hemacitômetro. A seguir, $50 \mu \mathrm{l}$ da suspensão e $50 \mu \mathrm{l}$ de cada indutor, nas concentrações citadas no item 4.2.1, foram misturados e colocados em lâminas de microscopia recobertas com filme de poliestireno (Leite \& Nicholson, 1992). Estas lâminas foram colocadas no interior de placas de Petri esterilizadas, contendo um chumaço de algodão embebido em água destilada. Estas foram seladas com plástico transparente e incubadas em câmara de crescimento àtemperatura de $26{ }^{\circ} \mathrm{C} \mathrm{e}$ luz fluorescente constante por $12 \mathrm{~h}$. Após este período, interrompeu-se 0 processo germinativo com adição de azul-de-algodão, sendo avaliadas a percentagem de germinação e formação de apressórios. Foram considerados 
como germinados os conídios com tubo germinativo maior que o comprimento do próprio picnidiósporos (Glienke, 1995).

\subsubsection{Delineamento experimental e avaliação estatística}

O ensaio para avaliação da indução de resistência em póscolheita consistiu de um delineamento inteiramente casualizado, no esquema fatorial ( 15 frutos $\times 5$ concentrações $\times 4$ tempos de exposição) em 3 repetições.

Em relação ao experimento de indução em pré-colheita, este foi conduzido em delineamento em blocos casualizados, em parcelas subdivididas no tempo (lotes de 25 mudas / 4 blocos com 5 doses dos indutores). Durante um mês, cada bloco de 25 mudas foi levado a campo (um bloco/semana).

Para se avaliar a influência dos indutores sobre o fungo in vitro, foi utilizado um delineamento inteiramente casualizado com 5 repetições. Foi realizada uma análise de variância e aplicou-se a análise de regressão para os fatores quantitativos (concentrações). Para a comparação das médias de tratamentos, aplicou-se o teste de Tukey a $5 \%$ de probabilidade. Os dados expressos em percentagem foram transformados em arco seno da raiz quadrada de $(x)$, antes de serem submetidos à análise de variância, segundo Gomes (1995).

\subsection{Resultados e discussão}

\subsubsection{Indução de resistência em pós-colheita}

Como para o fator quantitativo (concentrações dos indutores) as análises de regressão não foram significativas (apêndice 4), optou-se pela união das médias e uma interpretação descritiva no formato gráfico para os dados avaliados. Desta forma, com base nos resultados mostrados nas Figuras de 11, 12 e 13 nenhum dos indutores avaliados foi capaz de impedir ou diminuir 
o aparecimento de novas lesões nos frutos de laranja Pêra-Rio, em póscolheita, nas condições experimentais testadas.

Entretanto, a literatura mostra inúmeros trabalhos, onde frutos cítricos, em pós-colheita, têm os mecanismos de resistência ativados, como as fitoalexinas (escoparona e escopoletina), em resposta a diferentes tipos de indutores bióticos e abióticos (Arras, 1996; Rodov et al., 1994; Ali et al., 1991), levando a uma redução nos sintomas das doenças. Contudo, nesses trabalhos, os frutos foram tratados primeiramente com os indutores $\mathrm{e}$ inoculados com os patógenos logo a seguir, metodologia que difere da empregada neste ensaio, o que impede comparações mais objetivas. Desta forma, pode-se admitir, simplesmente, que nas concentrações e tempos de exposição avaliados, os indutores empregados ácido salicílico, Bion e $S$. cereviseae não foram capazes de induzir respostas de defesa nos frutos.

Para Wilson \& Wisniewski (1989) e Wisniewski \& Wilson (1992), antagonistas como Aureobasidium pullulans e Candida oerophila não são efetivos contra fitopatógenos que produzem infecções latentes ou que penetram diretamente no tecido vegetal, dentre os quais podemos citar G. citricarpa, Botrytis cinerea e Colletrotrichum capsici, C. musae e C. gloesporioides. Já está evidenciado na literatura que $S$. cereviseae é capaz de induzir respostas de defesa nas plantas (Roveratti, 1989; Silva \& Pascholati, 1992; Stargarlin \& Pascholati, 1994; Roncatto \& Pascholati, 1998; Wulff \& Pascholati, 1998).

Alguns trabalhos mostram que o uso de leveduras em póscolheita é efetivo no controle de infecções ocorridas através de ferimentos, durante a colheita (Ippolito \& Nigro, 2000). Entretanto, falham no controle de infecções previamente estabelecidas, como no caso das infecções latentes (Janisiewicz, 1998; Roberts, 1994). Além disso, existe uma tendência na literatura, que no caso das infecções latentes, o uso de agentes de controle seria mais eficaz quando aplicados na pré-colheita, na fase do florescimento, antes do estabelecimento do patógeno (Lima et al., 1997; Wittig et al., 1997; Ippolito \& Nigro, 2000). 
Em relação ao Bion e ácido salicílico, a literatura mostra que estes indutores abióticos são capazes de induzir resistência em diferentes plantas (Ryals et al., 1996) e sementes (Lantunde-Dada et al., 2001) e que devido a semelhança química estrutural, pode-se inferir que os mecanismos de ação destes compostos poderiam ser semelhantes, via ativação da resistência sistêmica adquirida (Anfoka, 2000). O Bion não é fitotóxico (Silva \& Resende, 2001; Benhamou \& Bélanger, 1998; Ryals et al., 1996) e já está registrado (Bion $500 W G($ ) para uso no Brasil, onde vem sendo aplicado com sucesso, por exemplo, no controle de Xanthomonas campestris pv. vesicatoria em tomateiro, também na proteção de mudas de cacau e citros contra Crinipelis perniciosa e Xylella fastidiosa, respectivamente (Silva \& Resende, 2001). A limitação para o uso do ácido salicílico em escala comercial é a sua fitotoxidade (Ryals et al., 1996; Benhamou \& Bélanger, 1998), fato verificado nas condições experimentais do presente trabalho, em concentrações acima de $1 \mathrm{mM}$ (dados não mostrados). Particularmente em relação ao Bion, a literatura mostra que este indutor de resistência pode ser empregado isoladamente ou em misturas com fungicidas (Ukness et al., 1996; Perez, 2002). Desta forma, o desempenho de um indutor de resistência pode certamente ser melhorado ou estabilizado, se associado a outros indutores, ou até com micronutrientes, que podem atuar como cofatores para várias enzimas envolvidas na síntese de substâncias de defesa da planta (Silva \& Resende, 2001).

A literatura mostra que uma variedade de indutores bóticos e abióticos podem induzir respostas de defesas em pós-colheita (Wilson et al., 1994), entretanto, são estudos isolados, enfatizando um ou outro mecanismo de indução de resistência.

Desta forma, muitos autores (Wisniewski \& Wilson, 1992; Wilson et al., 1994) acreditam que a combinação de diversos agentes bióticos e abióticos, aplicados simultaneamente, seja a chave para 0 biocontrole de fitopatógenos em pós-colheita. 


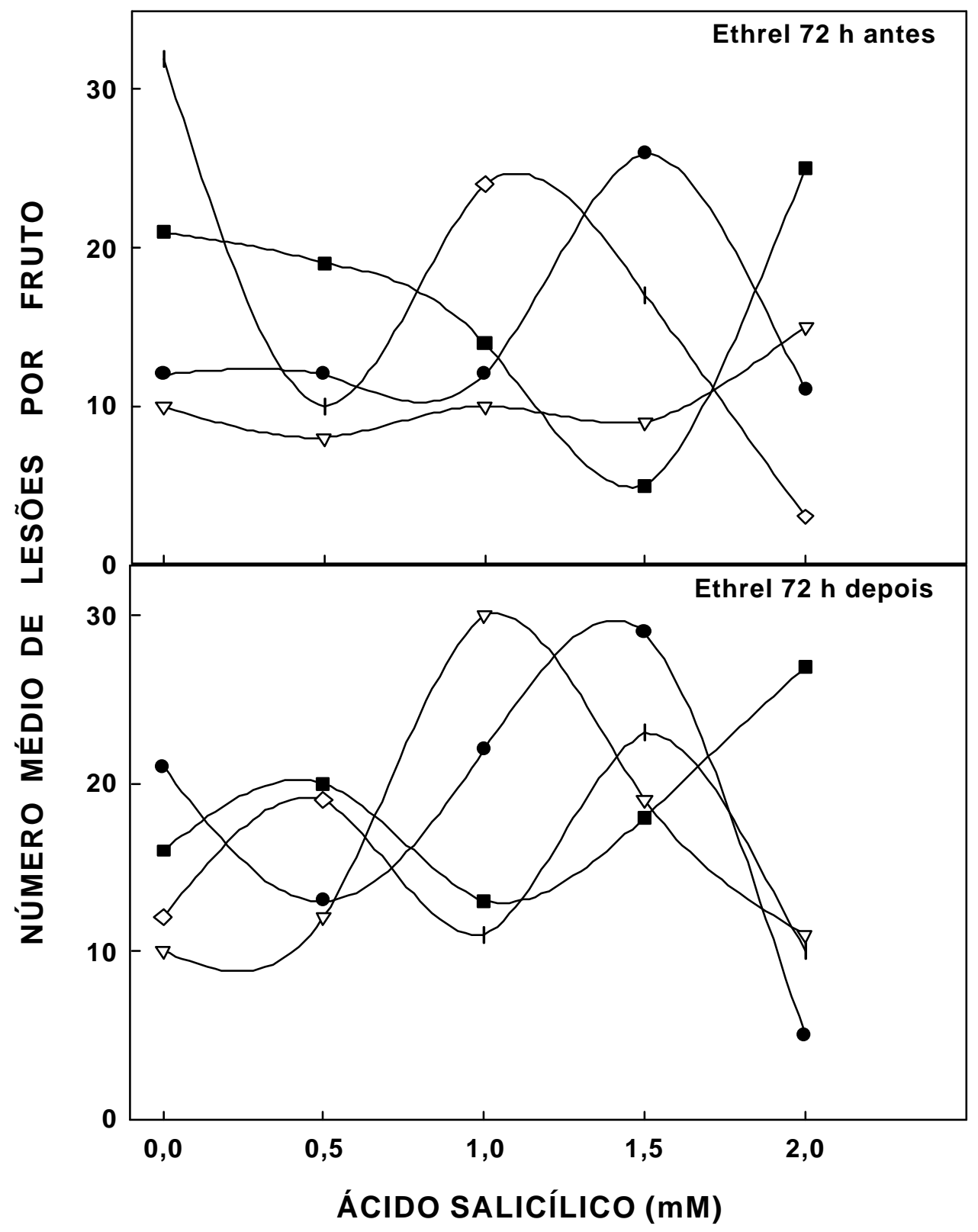

Figura 11 - Efeito do ácido salicílico em pós-colheita, aplicado em frutos sintomáticos de laranja (var. Pêra-Rio), em diferentes concentrações e tempos de exposição. Ethrel aplicado $72 \mathrm{~h}$ antes e depois do indutor. 20 minutos $(\bullet), 3$ horas $(\nabla), 6$ horas

(घ) e 10 horas ( ). 


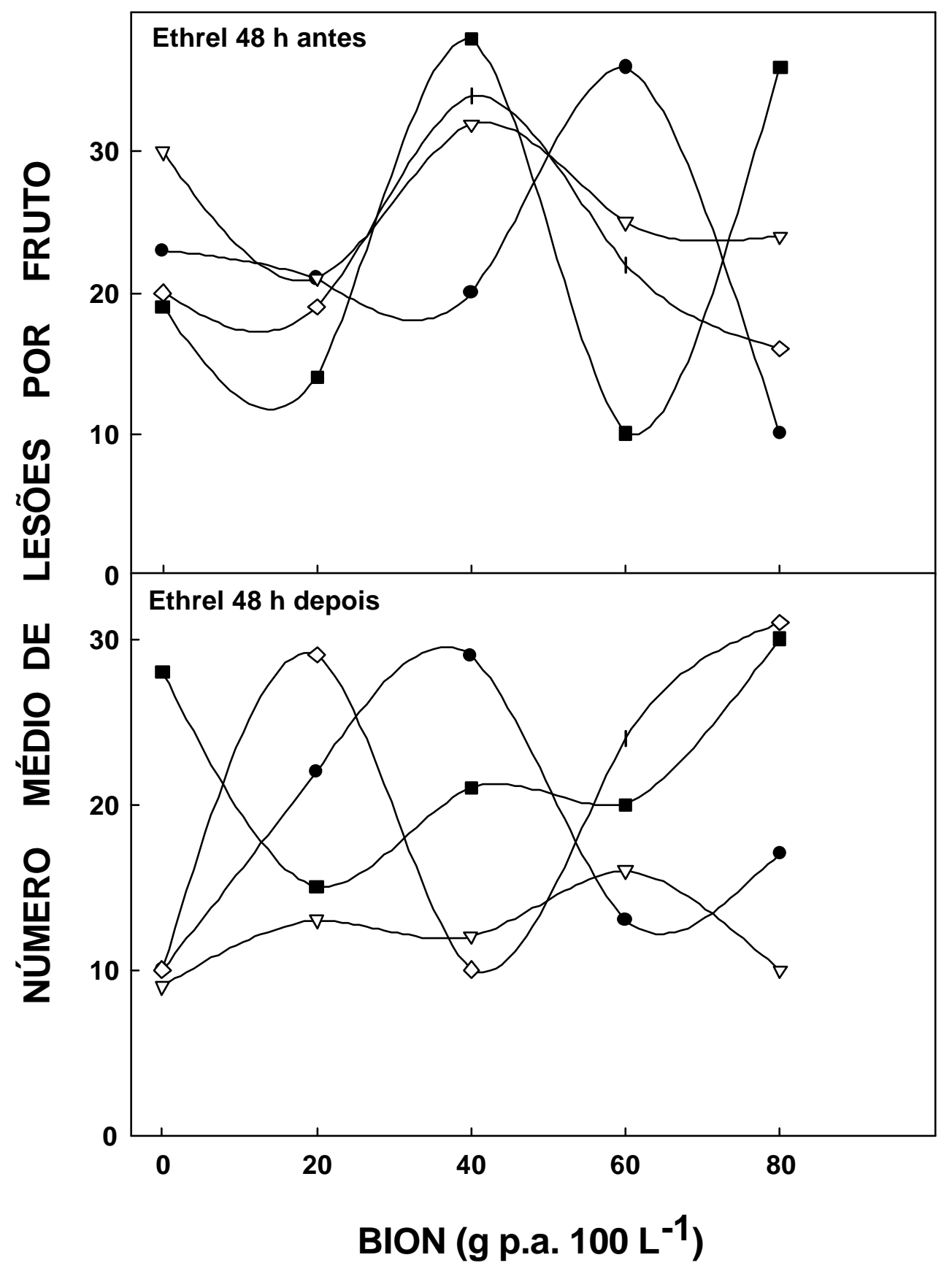

Figura 12 - Efeito do Bion em pós-colheita, aplicado em frutos sintomáticos de laranja (var. PêraRio), em diferentes concentrações e tempos de exposição. Ethrel aplicado $48 \mathrm{~h}$ antes e depois do indutor.20 minutos $(\bullet), 3$ horas $(\nabla), 6$ horas (ם) e 10 horas ( ). 


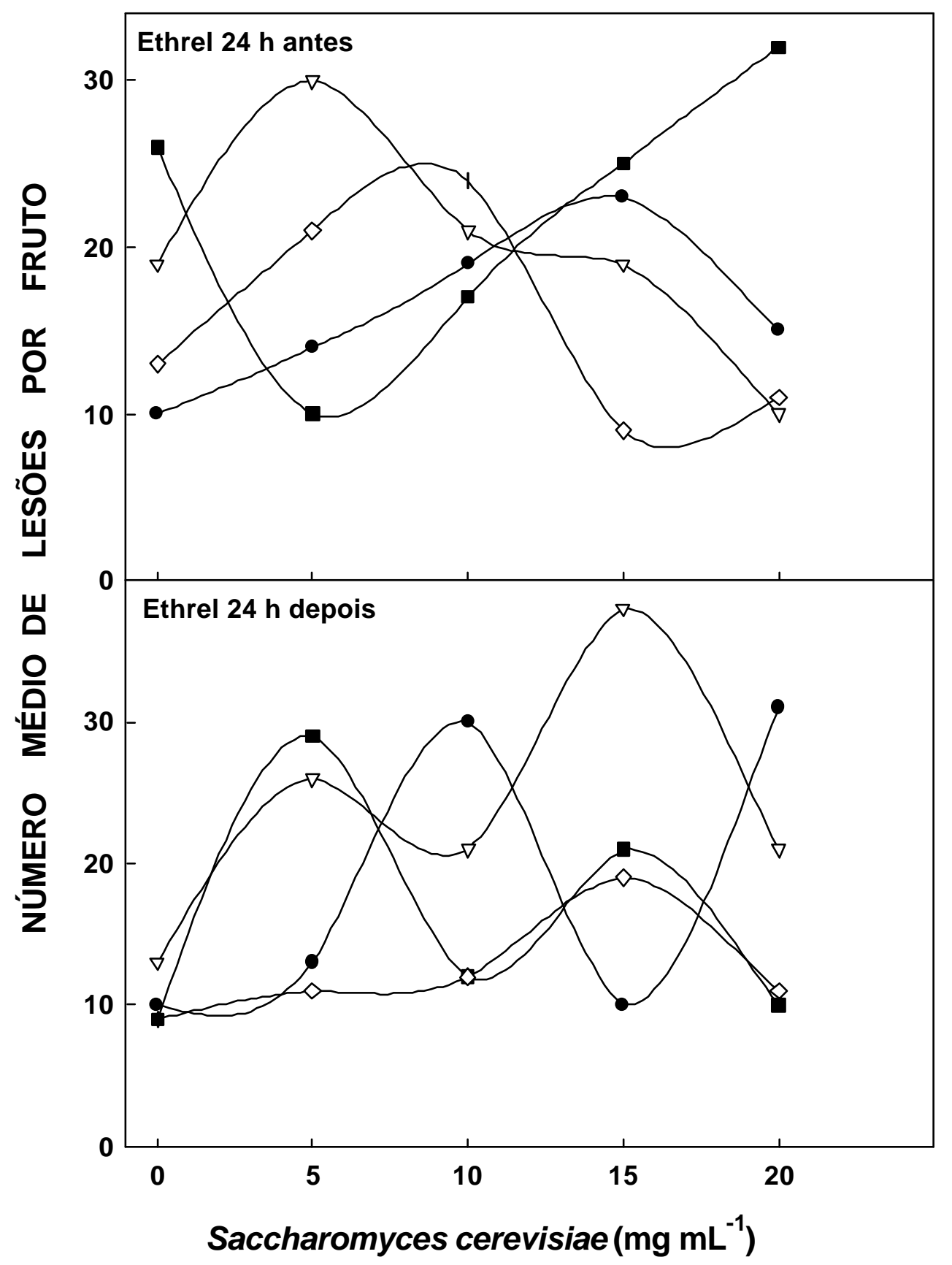

Figura 13 - Efeito de Saccharomyces cerevisiae em póscolheita, aplicado em frutos sintomáticos de laranja (var. Pêra-Rio), em diferentes concentrações e tempos de exposição. Ethrel aplicado $24 \mathrm{~h}$ antes e depois do indutor. 20 minutos $(\bullet), 3$ horas $(\nabla), 6$ horas

(ם) e 10 horas ( ). 


\subsubsection{Indução de resistência em pré-colheita}

A semelhança do item 4.3.1, a análise de regressão para os dados avaliados não apresentou significância estatística (dados não mostrados). Desta forma, também optou-se por uma análise descritiva para o fator quantitativo doses de indutores e as variáveis incidência (número de lesões / folha) e severidade (escala diagramática, Figura 10). Segundos os dados apresentados nas Figuras 14 e 15, nenhum dos indutores testados (Bion® e Saccharomyces cerevisiae), nas concentrações e tempos de exposição avaliados, foi capaz de induzir resistência a MPC em mudas de limão Siciliano. Também foi observado, nas condições experimentais testadas, que os sintomas só manifestaram-se nas folhas após um longo período de latência (dados não mostrados). Esta observação corrobora com os relatos de McOnie (1967) e Kotzé $(1981,1996)$. De acordo com Kotzé (1981) os peritécios são formados a partir de infecções ocorridas em folhas, normalmente assintomáticas, caídas no solo. Por sua vez, de acordo com Feichtenberger (1996) o desenvolvimento e maturação das estruturas reprodutivas do fungo ocorre alguns meses depois (em torno de 2 a 6 meses), favorecida pela alternância entre períodos de molhamento e seca das folhas. Segundo Kotzé $(1981,1996)$, a manifestação dos sintomas da MPC pode ser favorecida por inúmeros fatores, dos quais os de maior importância são temperaturas em torno de $27{ }^{\circ} \mathrm{C}$, precipitação pluviométrica em torno de $200 \mathrm{~mm}$ e alta radiação solar. As condições climáticas (Tabela 6) compreendidas entre outubro de 2001 a março de 2002 (período de permanência das mudas no campo), podem ter contribuído para a baixa incidência (Figuras 14 e 15) da doença nas mudas de limão. Ainda segundo os dados da Tabela 6 , a média das temperaturas $\left(24,9{ }^{\circ} \mathrm{C}\right)$ e precipitações pluvisiométricas $(59,1 \mathrm{~mm})$, quando comparadas com a literatura (Alcoba et al., 2000; Kotzé, 1981, 1996) não correspondem com as consideradas ideais $\left(27^{\circ} \mathrm{C}\right.$ e $212 \mathrm{~mm}$, respectivamente) para o desenvolvimento do fungo. 
Tabela 6. Dados climatológicos e de dispersão de ascósporos de Guignardia citricarpa observados durante os meses de permanência das mudas de limão Siciliano na Fazenda Bela Vista em Conchal-SP.

\begin{tabular}{lcccc}
\hline \multicolumn{5}{c}{ Dados climatológicos ${ }^{1}$} \\
\hline Mês/ ano & $\begin{array}{c}\text { No. de } \\
\text { ascósporos } \\
\text { observados }\end{array}$ & $\begin{array}{c}\text { Temperatura } \\
\text { média mensal } \\
\left({ }^{\circ} \mathrm{C}\right)\end{array}$ & $\begin{array}{c}\text { Umidade } \\
\text { relativa do ar } \\
(\%)\end{array}$ & Precipitação (mm) \\
$\begin{array}{l}\text { Outubro } \\
\text { (2001) }\end{array}$ & 19 & 22,8 & 64,0 & 38,7 \\
$\begin{array}{l}\text { Novembro } \\
(2001)\end{array}$ & 29 & 26,3 & 65,6 & 39,5 \\
$\begin{array}{l}\text { Dezembro } \\
(2001)\end{array}$ & 21 & 24,3 & 71,1 & 107,3 \\
$\begin{array}{l}\text { Janeiro } \\
(2002)\end{array}$ & 39 & 25,7 & 71,0 & 101,0 \\
$\begin{array}{l}\text { Fevereiro } \\
(2002)\end{array}$ & 14 & 24,1 & 72,9 & 41,3 \\
$\begin{array}{l}\text { Março } \\
\text { (2002) }\end{array}$ & 11 & 26,2 & 67,2 & 27,3 \\
\hline
\end{tabular}

1/ Dados fornecidos pelo engenheiro agrônomo Mário Moraes (Casa da Agricultura de Conchal)

2/ Dados fornecidos pelo professor Dr. Antônio Goes - Departamento de Fitossanidade-FCAV/UNESP. 


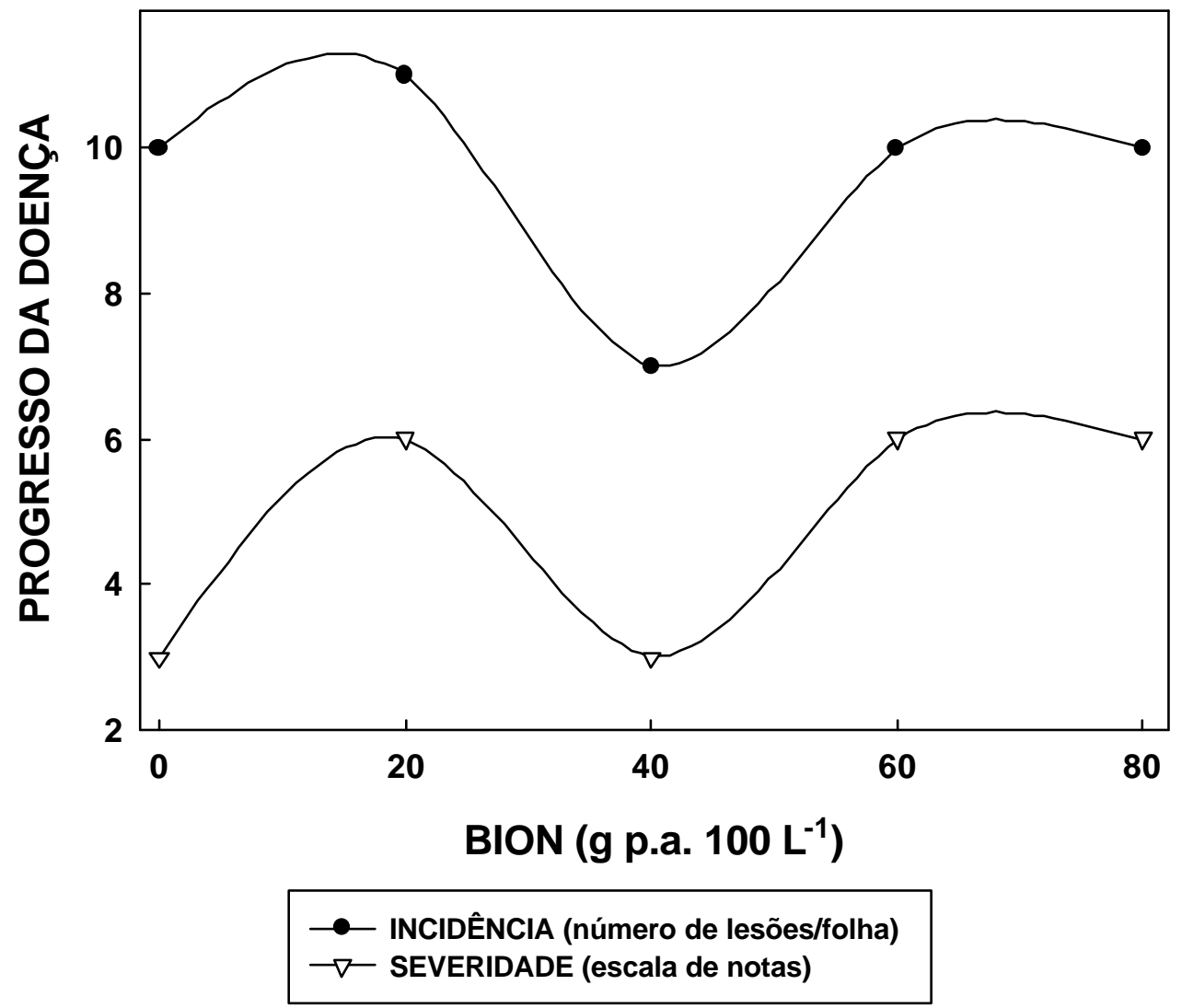

Figura 14 - Efeito do Bion no progresso da mancha preta dos citros em folhas de limão Siciliano (Citrus limonia), infectadas naturalmente a campo por Guignardia citricarpa. Dados médios de avaliações conduzidas durante os meses de março de 2001 a setembro de 2002. 


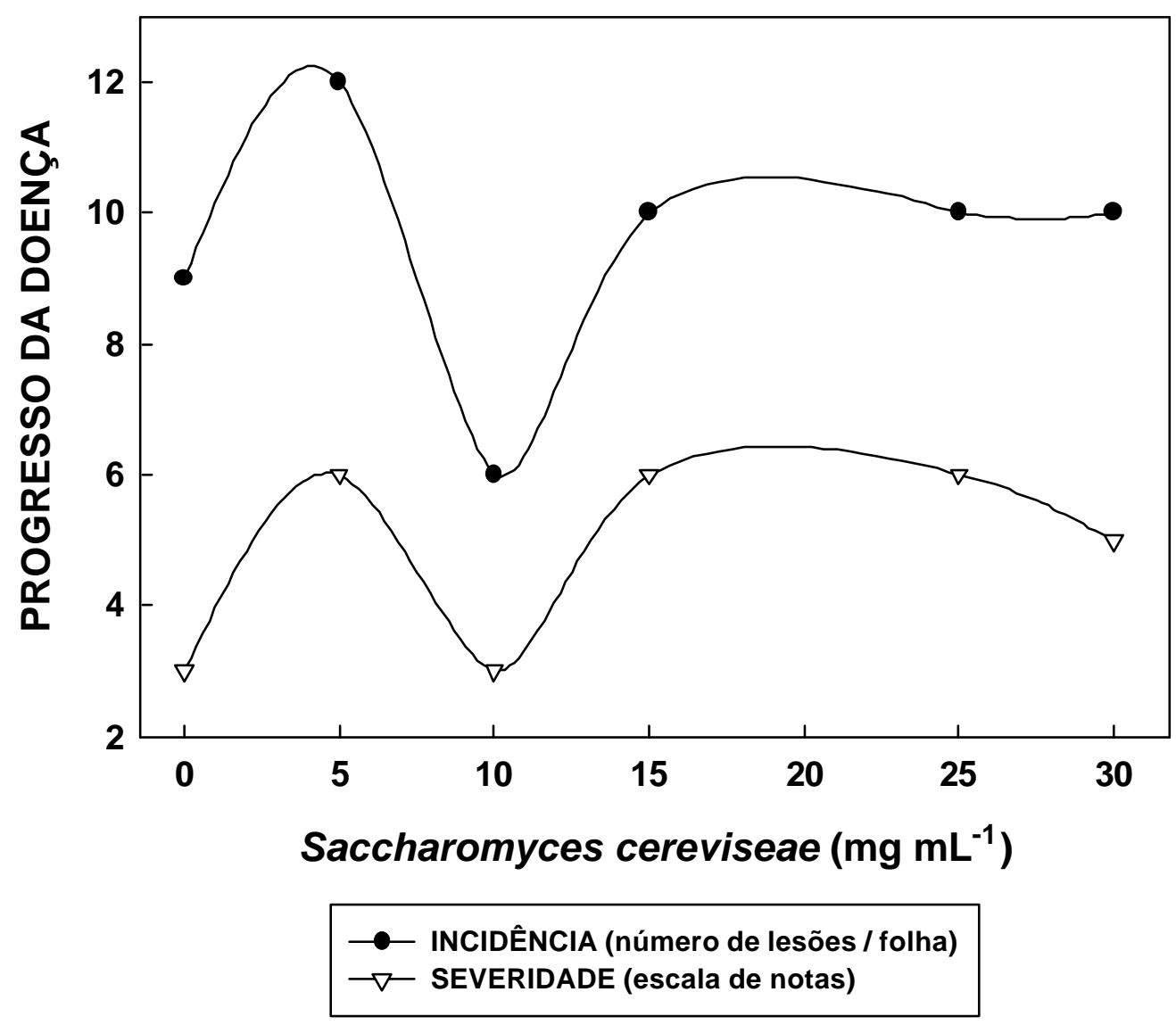

Figura 15 - Efeito de S. cerevisiae no progresso da mancha preta dos citros em folhas de limão Siciliano (Citrus limonia), infectadas naturalmente a campo por Guignardia citricarpa. Dados médios de avaliações conduzidas durante os meses de março de 2001 a setembro de 2002. 
De acordo com os dados experimentais (Figuras 14 e 15) o valor máximo de severidade da doença não ultrapassou a $14 \%$. Este índice de severidade pode ser considerado baixo, quando comparado com outras epidemias foliares, tais como a ferrugem do cafeeiro (Kranz, 1974, 1988) e pode ser resultante de um menor grau de dispersão do inóculo (número de ascósporos - Tabela 6), na área experimental durante o período de permanência das mudas no campo. Estas observações, corroboram com dados da literatura (Alcoba et al., 2000; Feichtenberger, 1996; Góes, 1998; Kotzé, 1981 , 1996) que sugerem que os ascóporos representam principal fonte de inóculo da MPC. É provável que a produção de ascósporos, em folhas infectadas que caíram ao solo e sofreram decomposição, não tenha sido suficientemente alta, contribuindo assim, para uma diminuição no número de propágulos do fungo e nas infecções de órgãos suscetíveis.

A presença de frutos nas mudas tratadas foi constatada após 12 meses depois da inoculação, tendo sido verificado que em todos os tratamentos o número de lesões foi superior a seis lesões por fruto (dados não mostrados). Este resultado, reforça a tese de que nenhum dos indutores testados foi capaz de induzir resistência também em pré colheita nas condições experimentais testadas.

\subsubsection{Influência dos indutores na germinação de conídios e formação de apressório}

No tocante aos efeitos dos indutores na germinação dos conídios e formação de apressório, optou-se também pela união das médias e uma interpretação descritiva no formato gráfico, pelas razões já citadas nos itens 4.3.1 e 4.3.2. Os resultados constantes das Figuras 16, 17 e 18 mostram efeitos diferenciados entre os indutores testados. Com relação aos dados constantes na Figura 18, os mesmos mostram que $S$. cereviseae inibiu totalmente a germinação e a formação de apressórios por G. citricarpa. 


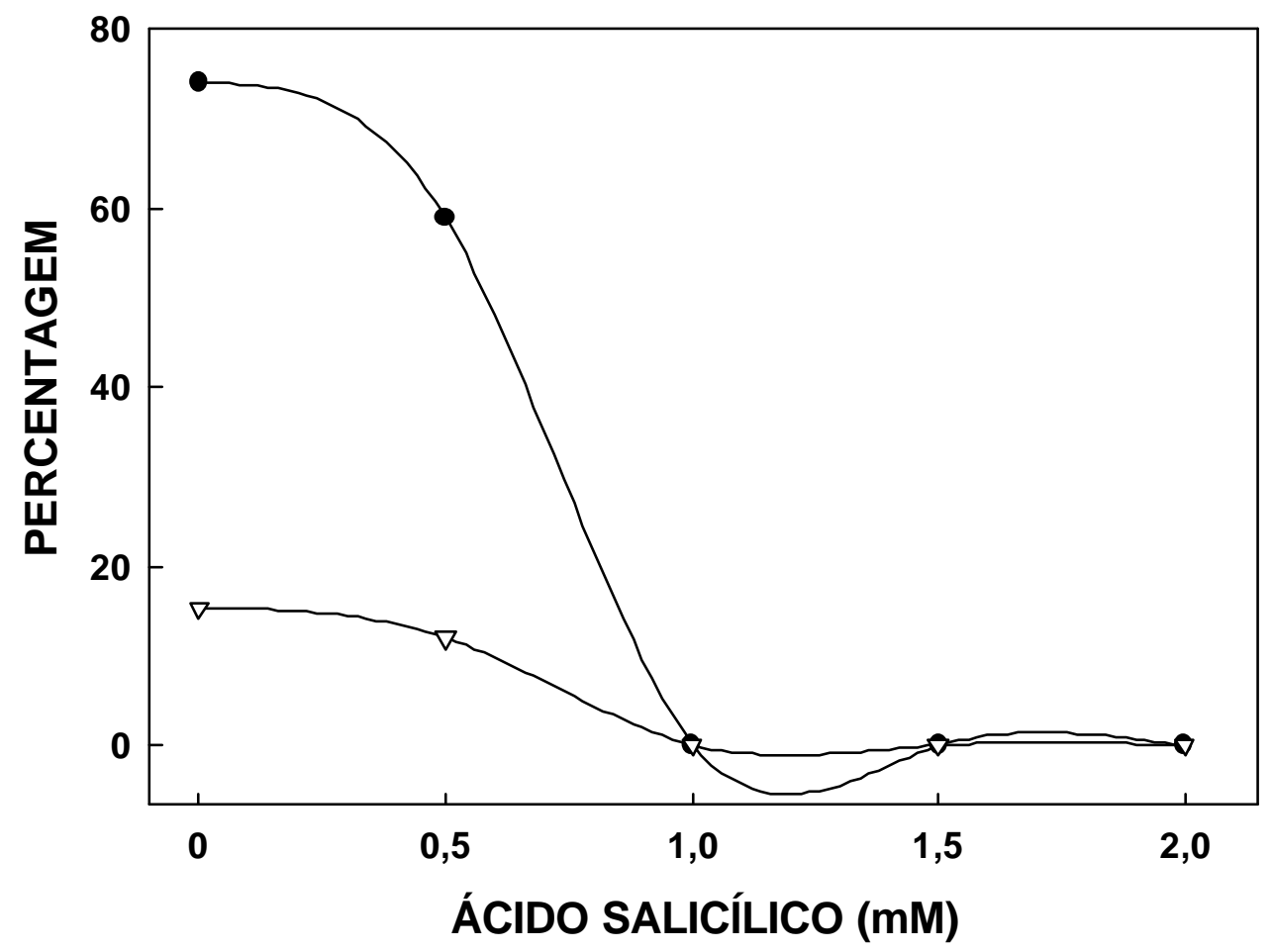

Figura 16 - Efeito in vitro de ácido salicílico na germinação de picnidiósporos e formação de apressório por Phyllosticta citricarpa após $12 \mathrm{~h}$ de incubação a $26{ }^{\circ} \mathrm{C}$, sob luz fluorescente constante. Germinação ( ), apressório ( $\nabla)$. 


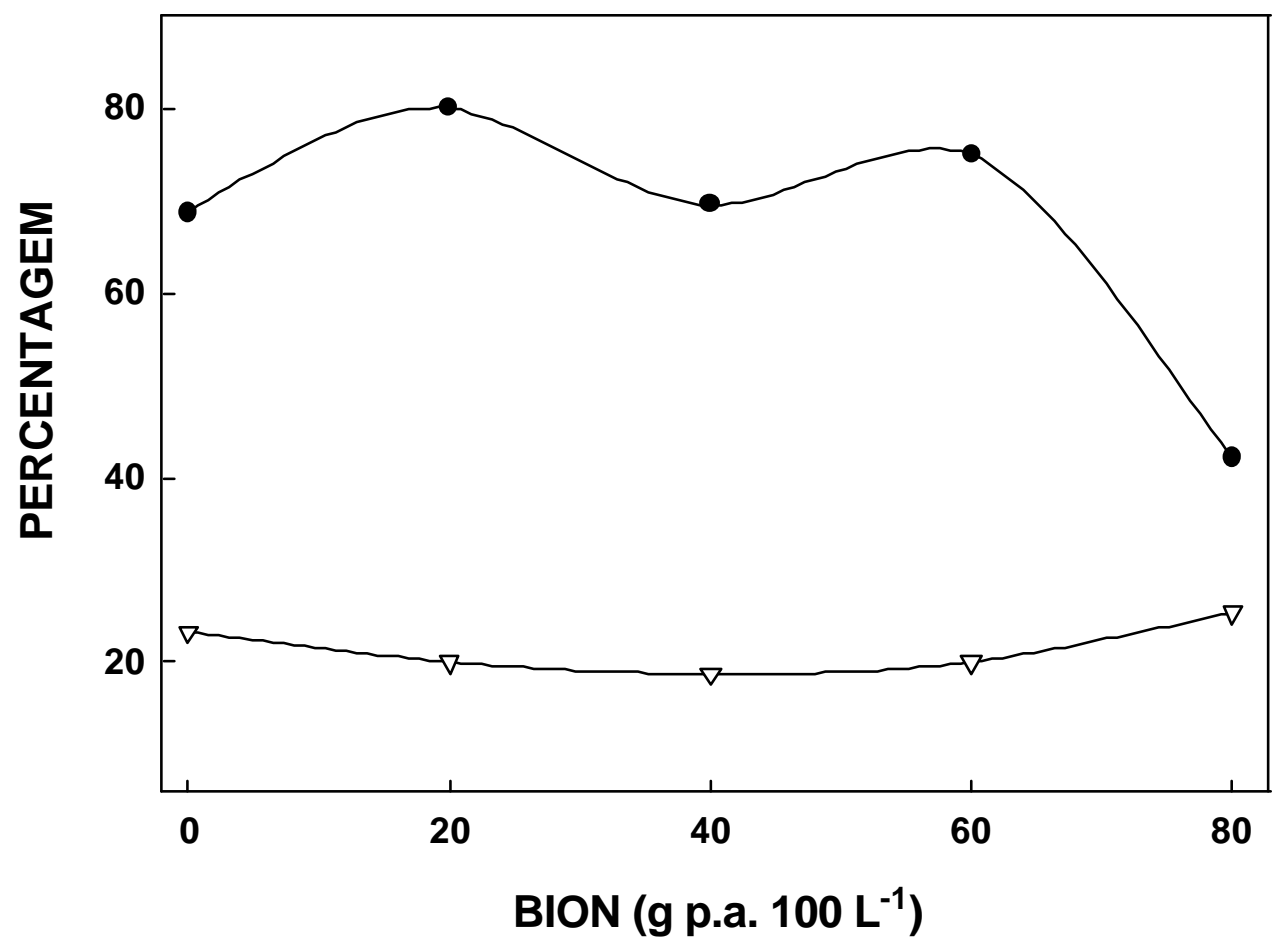

Figura 17 - Efeito in vitro do Bion na germinação de picnidiósporos e formação de apressório por Phyllosticta citricarpa após $12 \mathrm{~h}$ de incubação a $26{ }^{\circ} \mathrm{C}$, sob luz fluorescente constante. Germinação ( ), apressório ( $\nabla)$. 


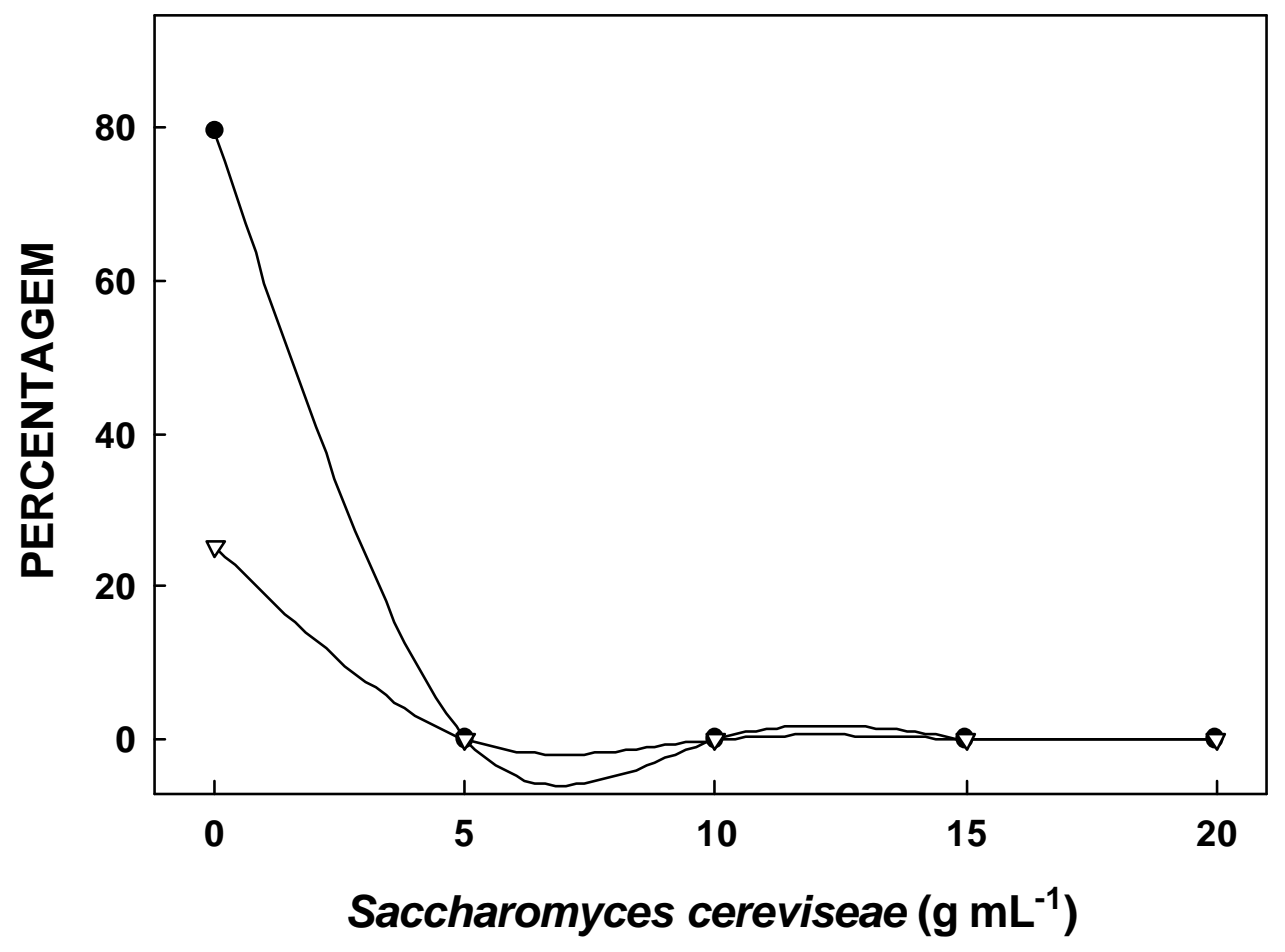

Figura 18 - Efeito in vitro de Saccharomyces cerevisiae na germinação de picnidiósporos e formação de apressório por Phyllosticta citricarpa após $12 \mathrm{~h}$ de incubação a $26{ }^{\circ} \mathrm{C}$, sob luz fluorescente constante. Germinação ( ), apressório ( $\nabla)$. 
Este desempenho pode ser comparado ao benomil na dose recomendada $\left(0,35 \mathrm{~g}\right.$ do p.a. $\mathrm{L}^{-1}$, dados não mostrados) que é o principal fungicida utilizado para o controle de G. citricarpa (dados não mostrados). Por outro lado, o Bion não inibiu a germinação e a formação de apressórios nas concentrações testadas (Figura 17), enquanto o ácido salicílico em concentrações a partir de 1,0 mM inibiu tanto a germinação quanto a formação de apressórios (Figura 16).

Existem evidências experimentais, de que o modo de ação das leveduras utilizadas como antagonistas biológicos, tais como Aureobasidium pullulans, Candida oerophila (Arras, 1996), Debaryomyces hansenii (Wilson \& Wisniewski, 1989) e Pichia guilliermondii (Wisniewski et al., 1991), utilizadas no biocontrole de patógenos de pós-colheita, pode variar deste a competição direta por nutrientes e espaço, micoparasitismo (Wilson et al., 1994), antibiose até a indução de resistência (Wisniewski \& Wilson, 1992). Portanto, a atuação in vitro de $S$. cereviseae na redução da germinação e formação de apressórios por $G$. citricarpa, poderia ser atribuída a liberação de uma substância ou complexo de substâncias com atividade inibitória, envolvendo a antibiose (Pascholati, 1998).

No tocante ao efeito do Bion in vitro, os resultados obtidos (Figura 17) não corroboram com Friedrich et al. (1996), Görlach et al. (1996) e Cole (1999) mostrando que o Bion exerceu efeito direto sobre $P$. citricarpa na concentração de 80 g p.a. / 100 L. Estes dados, entretanto, corroboram parcialmente com os obtidos por Pascholati et al. (1998), que demonstraram que o Bion inibiu a germinação de conídios e a formação de apressórios por Colletotrichum graminicola, além de reduzir o crescimento micelial in vitro.

Recentemente, Resende et al. (2000), baseando-se em valores $\left(365,05\right.$ e $\left.347,19 \mu \mathrm{g} \mathrm{mL}^{-1}\right)$ experimentais estimados para o Bion em relação à germinação de basidiósporos e crescimento micelial de Crinipellis perniciosa in vitro, classificaram o Bion como sendo pouco fungitóxico, pois de acordo com estes autores na classificação dos níveis de toxidez para fungos proposta por Edgington et al. (1971), compostos com $\mathrm{EC}_{50}>50 \mu \mathrm{g} \mathrm{mL} \mathrm{L}^{-1}$ podem ser 
considerados como pouco fungitóxicos. Ainda segundo Resende et al. (2000), a $\mathrm{EC}_{90}$ para o Bion ficou acima do limite de $1.000 \mu \mathrm{g} \mathrm{mL}^{-1}$, na maior dosagem testada, sugerindo que a ação deste produto seja mesmo a de indutor de resistência. Entretanto, o efeito do Bion sobre o patógeno não preenche a um dos requisitos para um composto seja classificado como um verdadeiro indutor de resistência, citados em Görlach et al. (1996), a de que um composto para ser considerado com indutor de resistência vegetal, não deve ter ação direta sobre o patógeno. Assim deste modo, talvez este critério de classificação precise ser revisado, possibilitando o uso de compostos que necessariamente preencham não todos os três critérios exigidos.

Por sua vez, em relação ao ácido salicílico, trabalhos evidenciam a ação fungitóxica (Chen \& Klessing, 1991; Durner \& Klessing, 1995) sobre fitopatógenos, o que reforça os resultados obtidos no presente trabalho, a partir da concentração de $1 \mathrm{mM}$ (Figura 16).

\subsection{Conclusões}

Saccharomyces cereviseae e o ácido salicílico reduziram a germinação e a formação de apressórios por $P$. citricarpa in vitro, porém não inibiram o aparecimento de novas lesões nos frutos em pós-colheita. Por outro lado, Bion influenciou negativamente apenas a germinação de picnidiósporos por $P$. citricarpa e também não inibiu o surgimento de novas lesões nos frutos tratados. Em pré colheita, nenhum dos indutores testados foi capaz de inibir o surgimento de lesões em folhas de mudas de limão Siciliano inoculadas naturalmente. 


\section{CONCLUSÕES GERAIS}

Os extratos de albedo de laranja testados exibem, a depender da concentração utilizada ação fungicida ou fungistástica, inibindo a germinação, esporulação e o crescimento micelial de Phyllosticta citricarpa in vitro.

Os indutores avaliados (ácido salicílico, Bion e Saccharomyces cerevisiae) não foram de induzir resistência ao patógeno, em frutos de Citrus sinensis (var. Pêra-Rio) em pós-colheita e em pré-colheita, em folhas de Citrus limonia (limão Siciliano), nas doses e tempos de exposição testados.

Os indutores ácido salićlico e $S$. cerevisiae, foram capazes de controlar a germinação picnidiósporos e a formação de apressório de $P$. citricarpa in vitro, ao passo que o Bion só exerceu efeito apenas sobre a germinação. 


\section{REFERÊNCIAS BIBLIOGRÁFICAS}

ADIKARAM, N. K. B.; BROWN, A. E.; SWINBURNE, T. R. Phytolaexin involvement in latent infection of Capsicum annuum L. fruit by Glomerella cingulata (Stoenem.). Physiological Plant Pathology, v. 21, p. 161-170, 1982.

AFEK, U.; SZTEJNBERG, A. Accumulation of scoparone, a phytoalexin associated with resistance of citrus to Phytophthora citrophthora. Phytopathology, v. 78, p. 1678-1682, 1988.

AFEK, U.; SZTEJNBERG, A.; CARMELY, S. 6,7-Dimethoxycoumarin, a Citrus phytoalexin conferring resistance against Phytophthora gummosis. Phytochemistry, v. 25, p. 1855-1856, 1986.

AFEK, U.; ORENSTEIN, J.; CARMELI, S.; RODOV, V.; MOSHE, B.J. Umbelliferone, a phytoalexin associated with resistance of immature grapefruit to Penicillium digitatum. Phytochemistry, v. 50, p. 1129-1132, 1999.

AGOSTINI, J. P.; TIMER, L. W.; MITCHELL, D.J. Morphological and pathological characteristics of strains of Colletotrichum gloeosporioides from citrus. Phytopathology, v. 82, p. 1377-1382, 1992.

AGRIOS, G. N. Plant pathology. 4. ed. San Diego: Academic Press, 1997. $635 p$.

AIST, J. R.; GOOLD, R. E.; BAYLES, C. J.; MORRISON, G. H.; CHANDRA, S.; ISRAEL, H. W. Evidence that molecular components of papilla may be involved in $\mathrm{ml}-\mathrm{o}$ resistance to barley powdery mildew. Physiology Molecular Plant Pathology, v. 33, p. 17-33, 1988.

AKHTAR, J. K.; VERNENGHI, A.; RAVISE, A. Incidence of fosetyl Al and elicitors on the defence reactions of Citrus attacked by Phytophthora spp. Fruits, v.41, p. 587-595, 1986. 
AKHTAR, J. K.; KUNESCH, G.; CHUILON, S.; RAVISE, A. Structure and biological activity of xanthyletin a new phytoalexin of Citrus. Fruits, v. 40, p.807-811, 1985.

ALBACH, R. F.; REDMAN, G. H. Composition and inheritance of flavanones in Citrus fruit. Phytochemistry, v. 8, p.127-143, 1969.

ALBACH, R. F.; REDMAN, G. H.; CRUSE, R. R. Annual and seasonal changes in naringin concentrations of ruby red grapefruit juice. Journal of Agricultural and Food Chemistry, v. 29, p. 808-811, 1981.

ALBRECHT, C.; ASSELINA, A.; PICHÉ, Y.; LAPEYRIE, F. Chitinase activities are induced in Eucalyptus globulus roots by ectomycorrhizal or pathogenic fungi, during early colonization. Physiologia Plantarum, v. 91, p.104-110, 1994.

ALCOBA,N.J.; VIGIANI,A.R.; BEJARANO,N.V.; ALVAREZ,S.E; SERRANO, M.A.; BONILLO,M.C. Mancha negra de los citros: epidemiologia y control. San Salvador de Jujuy: Ediciones Universidad Nacional de Jujuy, 2000. 56p.

ALEF, K. Enrichment, isolation and counting of soil microrganisms. In: ALEF, K.; NANNIPIERI, P. (Ed.). Methods in applied soil microbiology and biochemistry. London: Academic Press, 1995. cap. 4, p. 123-191.

ALI, M. K.; LEPOIVRE, P.; SEMAL, J. Fosetyl-Al treatment of Phytophthora citrophthora releases a higher scoparone elicitor activity from fosetyl-Al sensitive strain mutant than from an insensitive mutant. Fruits, v. 46, p. 51-55, 1991.

ALMEIDA, J. G. F. Barreiras æ̀̀ exportações de frutas tropicais. Fitopatologia Brasileira, v.27, p.7-10, 2002.

AMADIOHA, A. C. Controlling rice blast in vitro and in vivo with extracts of Azadirachta indica. Crop Protection, v.19, p. 287-290, 2000.

AMARO, A. A.; MAIA, M. L. Produção e comércio de laranja e de suco no Brasil. Laranja, v.18,p.1-26, 1997.

ANDREU, A.; TONÓN, C.; VAN DAMME, M.; HUARTE, M.; DALEO, G. Effect of glucans from different races of Phytophthora infestans on defense reactions in potato tuber. European Journal of Plant Pathology, v.104, p.777-783, 1998. 
ANFOKA, G. H. Benzo-(1,2,3)-thiadiazole-7-carbothioic acid S-methyl ester induces systemic resistance in tomato (Lycopersicum esculetum. Mill. Cv. Vollendung) to cucumber mosaic virus. Crop Protection, v.19, p. 401405, 2000.

ANIS, M.; AMINUDDIN. E. Flavonoid patterns of leaves of some Citrus species and their hybrids. Plant Biochemical Journal, v. 8, p. 56-60, 1981.

ARRAS, G. Mode of action of an isolate of Candida famata in biological control of Penicillium digitatum in orange fruits. Postharvest Biology and Technology, v. 8, p. 191-198, 1996.

AVERNA-SACCÁ, R. Pústulas pretas sobre laranjas doces produzidas pelo Phoma citricarpa. Revista de Agricultura, Piracicaba, v. 15, p. 668-74, 1940.

AZEVEDO, J. L. de Microrganismos endofíticos. In: MELLO, I. S.; AZEVEDO, J. L. de (Ed.). Ecologia microbiana. Jaguariúna: EMBRAPA, CNPMA, 1998. cap.4, p. 117-137.

BAAYEN, R. P.; BONANTS, P. J. M.; VERKLEY, G.; CARROLL, G. C.; VAN der Aa, H. A.; WEERDT, M. de; VAN BROUWERSHAVEN, I.R.; Schutte,G.C.; MACCHERONI Jr., W.; de BLANCO,C.G.; AZEVEDO,J.L. Nonpathogenic isolates of citrus black spot fungus, Guignardia citricarpa, identified as a cosmopolitan endophyte of woody plants, G. mangiferae (Phyllosticta capitalensis). Phytopathology, v. 92, p. 464-77, 2002.

BAPTISTA, M. J. Envolvimento de exsudatos radiculares, compostos fenólicos e enzimas vegetais na compatibilidade entre isolados do fungo etomicorrízico Pisolithus tinctorius e plântulas de Eucaliptus urophyla. Piracicaba, 2000. 115p. Tese (Doutorado) - Escola Superior de Agricultura Luiz de Queiroz, Universidade de São Paulo.

BECKMAN, C. H. Phenolics: keys to programmed cell death and periderm formation in wilt disease resistance and in general defence responses in plants ?. Physiological and Molecular Plant Pathology, v.57, p. 101-10, 2000.

BELL, A. A. Time sequence of defense. In: HORSFALL, J.G.; COWLING, E.B. (Ed.). Plant disease. New York: Academic Press, 1980. p. 53-73. 
BELL, J. N.; RYDER, T. B.; WINGATE, V. P. M.; BAILEY, J. A.; LAMB, C. J. Differential accumulation of plant defense gene transcripts in a compatible and an incompatible plant-pathogen interaction. Molecular and Cellular Biology, v.6, 1615-23, 1986.

BENATO, E. A. Controle de doenças em pós-colheita em frutas tropicais. Summa Phytopathologica, v. 25, p. 90-93, 1999.

BENHAMOU, N.; BÉLANGER, R. R. Benzothiadiazole-mediated induced resistance to Fusarium oxysporum f.sp. radicis-lycopersici in tomato. Plant Physiology, v. 118, p. 1203-1212, 1998.

BETTIOL, W. (Ed.). Controle biológico de doenças de plantas. Jaguariúna: Embrapa, CNPDA, 1991. 388p. (Embrapa CNPDA. Documentos, 15).

BINYAMINI, N.; SCHIFFMANN-NADEL, M. Latent infection in avocado fruit due to Colletotrichum gloeosporioides. Phytopathology, v. 62, p. 592-94, 1972.

BLANCO, de G.C. Guignardia citricarpa Kiely: análise genética, cariotípica e interação com o hospedeiro. Piracicaba, 1999. 200p. Tese (Doutorado). Escola Superior de Agricultura Luiz de Queiroz, Universidade de São Paulo.

BORRIS, R. P. Natural products research: perspectives from a major pharmaceutical company. Journal of Etnopharmacology, v. 51, p. 2938, 1996.

BOSTOCK, R.M. Signal conflicts and synergies in induced resistance to multiple attackers. Physiological and Molecular Plant Pathology, v. 55, p. 99-109, 1999.

BRASIL. Ministério da Agricultura, Pecuária e Abastecimento. AGROFIT. (www.agricultura.gov.br) (27 nov. 2002)

BRAY, H. G.; THORPE, W. V. Analysis of phenols compounds of interest in metabolism. Methods in Biochemistry Analysis, v.1, p.1194-96, 1954.

BRODRICK, H. T.; RABIE, C. J. Light and temperature effects on symptom development and sporulation of Guignardia citricarpa Kiely, on Citrus sinensis (Linn.) Osbeck. Phytophylactica, v.2, p. 157-64, 1970. 
BROWN, G. E. Ultrastructure of penetration of ethylene-degenerated Robinson tangerines by Colletotrichum gloesporioides after ethylene treatment. Phytopathology, v. 68, p.700-6, 1977.

BROWN, G. E.; BURNS, J .K. Factors affecting susceptibility of ethylene degreened oranges to Diplodia stem-end rot. Phytopathology, v. 85, p.1123, 1995. Abstract. /Apresentado ao 87., Annual Meeting of American Phytopathological Society, Pittsburgh, 1995 - Abstract/

BROWN,G.E. Factors affecting postharvest development of Colletotrichum gloesporioides in Citrus fruits. Phytopathology, v. 65, p. 404-9, 1975.

BRUZZESE, E.; HASAN, S. A whole leaf clearing and staining technique for host specificity studies of rust fungi. Plant Pathology, v. 32, p. 335-38, 1983.

CADENA-GOMEZ, G.; NICHOLSON, R. L. Papilla formation and associated peroxidase activity: a non-specific response to attempted fungal penetration of maize. Physiological Molecular and Plant Pathology, v. 31, p. 51-67, 1987.

CALAVAN, E. C. Black spot of citrus. The California Citrograph, v. 46, p. 22-24, 1960.

CATARINO, V.; GHINI, R.; BETTIOL, W.; SCRAMIN, S.; ZAVATTI, L.M.S. Efeito de extratos de Vernonia condensata e Tagetes minuta sobre germinação de uredinosporos de Hemileia vastatrix. In: WORKSHOP SOBRE PRODUTOS NATURAIS NO CONTROLE DE PRAGAS, DOENÇAS E PLANTAS DANINHAS, 1., Jaguariúna, 1990. Anais. Jaguariúna: Embrapa, CNPDA, 1990. p.31.

CERKAUSKAS, R, F. Latent colonization by Colletotrichum spp. epidemiological considerations and implications for mycoherbicides. Canadian Journal of Plant Pathology, v.10, p. 297-310,1988.

CHEN, Z.; KLESSIG, D. F. Identification of a soluble salicylic acid-binding protein that may function in signal transduction in the plant diseaseresistance response. Proceedings of the National Academy of Science of the USA, v. 88 , p. 8179-8183,1991

CITRUSFEAT. Fresh citrus situation. FASonline. Horticultural \& Tropical ProductsDivision.2001 (www.faz.usda.gov/htp/circular/2001/10/08/citrusf eat.htm). (16 set. 2002). 
COHEN, Y. Induced resistance against fungal diseases by aminobutyric acids. In: LYR, R.; RUSSEL, P. E.; SISLER, H. D. (Ed.). Modern fungicides and antifungal compounds. Andover: Intercept, 1996. cap. 57 , p. 461-466.

COLE, D. L. The efficacy of acibenzolar-S-Methyl, an inducer of systemic acquired resistance, against bacterial and fungal diseases of tobacco. Crop Protection, v. 18, p. 276-273, 1999.

COLLINS, C. H.; BRAGA, G. L.; BONATO, P. S. Introdução a métodos cromatográficos. 4. ed. Campinas: Editora da UNICAMP, 1990.273p.

COOK,R.J.;BAKER,K.F. The nature and practice of biological control of plant pathogens. St. Paul: APS Press, 1983. 539p.

COSTET, L.; CORDELIER, S.; DOREY, S.; BAILLIEUL, F.; FRITIG, B.; KAUFFMANN, S. Relationship between localized acquired resistance (LAR) and the hypersensitive response (HR): HR is necessary for LAR to occur and salicylic acid is not sufficient to trigger LAR. Molecular PlantMicrobe Interactions, v. 12, p. 655-662, 1999.

COWAN, M. M. Plant products as antimicrobial agents. Clinical Microbiology Reviews, v. 12, p. 564-582, 1999.

CRAMER, C. L.; BELL, J. N.; RYDER, T. B.; BAILEY, J. A.; SCHUCH, W.; BOLWELL, G.P. Co-ordinated synthesis of phytoalexin biosynthetic enzymes in biologically-stressed cells of bean (Phaseolus vulgaris L.). EMBO Journal, v. 4, p.285-289, 1985.

CRUICKSHANK,R.H.;WADE,G.C. The activation of latent infections of Monilinia fructicola on apricots by volatiles from the ripening fruit. Journal of Phytopathology, v.136,p.107-112, 1992.

CUYPERS, B.; SCHMELZER, E.; HAHLBROCK, K. In situ localization of rapidly accumulated phenylalanine ammonia lyase mRNA around penetration sites of Phytophthora infestans in potato leaves. Molecular Plant-Microbe Interactions, v. 1, p. 157-60, 1988.

DAAYF, F.; ONGENA, M.; BOULANGER, R.; EL HADRAMI, I.; BELANGER, R.R. Induction of phenolic compounds in two cultivars of cucumber by treatment of healthy and powdery mildew-infected plants with extracts of Reynoutria sachalinensis. Journal of Chemical Ecology, v. 26, p.15791593, 2000. 
DANIEL, M.; PURKAYASTHA, R. P. Handbook of phytoalexin metabolism and action. New York: Marcel Dekker, 1995. 615p.

DAUGROIS, J. H.; LAFITE, C.; BARTHE, J. P.; TOUZE, A. hduction of $\beta$ 1,3- glucanase in compatible and incompatible interactions between Colletrotrichum lindemuthianum and bean cultivars. Journal of Phytopathology, v.130,p.225-34, 1990.

DEY, P. M.; HARBORNE, J. B. Methods in plant biochemistry: plant science laboratories. London: Academic Press, 1989. vol. 1, 552p.

DEY, P. M.; HARBORNE, J. B. Plant biochemistry. New York: Academic Press, 1997. 554p.

DIXON, R. A.; BENDALL, D .S. Changes in the levels of enzymes of phenylpropanoid and flavonoid synthesis during phaseolin production in cell suspension cultures of Phaseolus vulgaris. Physiological Plant Pathology, v.13, p. 295-306, 1978.

DIXON, R. A.; DEY, P. M.; LAMB, C. J. Phytolaexin induction in French bean. Plant Physiology, v. 71, p. 251-256, 1983.

DIXON, R. A.; DEY, P. M.; MURPHY, D. L.; WHITEHEAD, I. M. Dose responses for Colletotrichum lindemuthianum elicitor-mediated enzyme induction in French cell suspension cultures. Planta, v.151, p. 272-280, 1981.

DURNER, J.; KLESSIG, D. F. inhibition of ascorbate peroxidase by salicylic acid and 2.6-dichloroisonicdinic acid, two inducers of plant defense responses. Proceedings of the National Academy of Science of the USA, v. 92, p. 11312-11316, 1995.

DYER, J. R. Applications of absorption spectroscopy of organic compounds. London: Prentice-Hall, 1965. 155p.

EBEL, J. Phytoalexin synthesis: the biochemical analysis of the induction process. Annual Review of Phytopahtology, v. 24, p.235-264, 1986.

ECKERT, J. W.; RATNAYAKE, M. Role of volatile compounds from wounded oranges on germination of Penicillium digitatum conidia. Phytopathology, v.84, p. 746-50, 1994.

EDEN BIOSCIENCE. http://www.edenbio.com/ms/msl.html. (20 dez. 2002). 
EDGINTON, L. V.; KNEW, K. L.; BARRON, G. L. Fungitoxic spectrum of benzimidazole compounds. Phytopathology, v. 62, p. 42-44, 1971.

ELGERSMA, D. M.; LIEM, J. I. Accumulation of phytoalexins in susceptible and resistant near-isogenic lines of tomato infected with Verticillium alboatrum or Fusarium oxysporum f.sp. lycopersici. Physiological and Molecular Plant Pathology, v. 34, p. 545-555, 1989.

EL-TOBSHY, Z.; SINCLAIR, J. B. Inhibition in vitro of Phomopsis citri by extracts from orange and by fungicides. Plant Disease Reporter, v. 48, p.925-927, 1964.

FEICHTENBERGER, E. Mancha preta dos citros no Estado de São Paulo. Laranja, v.17, p.93-108, 1996.

FELDMAN, A. W.; HANKS, R. W. Phenolic content in the roots and leaves of tolerant and susceptible citrus cultivars attacked by Radopholus similis. Phytochemistry, v. 7, p. 5-12, 1968.

FERNANDEZ ,M. R.; HEATH, M. C. Interaction of the no host French bean plant (Phaseolus vulgaris) with parasitic and saprophytic fungi. II. Cytological detectable responses. Canadian Journal of Botany, v.67, p. 686-687, 1989.

FRANCO, D. A. S.; BETTIOL, W. Controle de Penicillium digitatum em póscolheita de citros com produtos alternativos. Fitopatologia Brasileira, v. 25 , p. 602-606, 2000.

FREITAS, J.C.; ZARAMELA, G.S.; PASCHOLATI, S.F. Efeito de agentes bióticos e abióticos no acúmulo de um complexo de pigmentos e fitoalexinas em mesocótilos de sorgo. Fitopatologia Brasileira, v.18, p.349, 1993. Suplemento /Apresentado ao 26., Congresso Brasileiro de Fitopatologia, Aracaju, 1993 - Resumo/.

FRIEDRICH, L.; LAWTON, K.; RUESS, W.; MASNER, P., SPECKER, N. RELLA, M. G.; MEIER, B.; DINCHER, S.; STAUB, T.; UKNES, S.; MÉTRAUX, J.P.; KESSMANN, H.; RYALS, J. A benzothiadiazole derivative induces systemic acquired resistance in tobacco. The Plant Journal, v.10, p.61-70, 1996.

FRITZEMEIER, K. H.; CRETIN, C.; KOMBRINK, E. ;ROWEER, F.;TAYLOR, J. Transient induction of phenylalanine ammonia lyase and 4coumarate;CoA ligase mRNAs in potato leaves infected with virulent and avirulent races of Phytophthora infestans. Plant Physiology, v. 85, p. 34$41,1987$. 
FUNDECITRUS. Manual técnico sobre Pinta Preta. Araraquara:Fundo Paulista de Defesa da Agricultura, 2000. 10p. (Boletim Técnico,Edição especial).

GAMA, G. B. M. N. da; MEDEIROS, J. X. de; PINHEIROS, L. E. L. O comércio da cooperação como fator de desenvolvimento para o sistema de agroindústria de citros. Laranja, v. 21, p. 239-258, 2000.

GHINI,R.; KIMATI, H. Resistência de fungos a fungicidas. Jaguariúna: Embrapa Meio Ambiente, 2000. 78p.

GLIENKE, C. Variabilidade genética do fungo endofítico Guignardia citricarpa Kiely detectada por RAPD. Curitiba, 1995. 115p. Dissertação (Mestrado)- Universidade Federal do Paraná.

GODSHALL M. A.; LONERGAN, T. A. The effects of sugarcane extracts on the growth of the pathogenic fungus, Colletotrichum falcatum. Physiological an Molecular Plant Pathology, v. 30, p. 229-308, 1987.

GÓES, A. de Controle da mancha-preta dos frutos cítricos. Laranja, v. 9, p.293-304, 1998.

GÓES, A. de Efeito da combinação de fungicidas sistêmicos e protetores no controle da mancha preta dos frutos cítricos cusada por Guignardia citricarpa. Summa Phytopathologica, v. 28, p. 9-13, 2002.

GÓES, A. de; FEICHTENBERGER, E. Ocorrência da mancha preta causada por Phyllosticta citricarpa (Mc.Apl.) Van der Aa. (Guignardia citricarpa Kiely) em pomares cítricos do estado de São Paulo. Fitopatologia Brasileira, v. 18, p.138, 1993. Suplemento. /Apresentado ao 26., Congresso Brasileiro de Fitopatologia, Aracaju, 1993. - Resumo/

GÓES, A.; ANDRADE, A. G.; MORETTO, K. C. K. Efeito de diferentes tipos de óleos na mistura de benomyl + mancozeb no controle de Guignardia citricarpa, agente causal da mancha preta dos frutos cítricos. Summa Phytopathologica, v. 26, p. 233-236, 2000.

GÓES, A. de; BARROS, J. C. S.M. de; GRAÇA, J.; CASTRO, N. G.; MARTINS, S. P. Determinação da época de produção de infecções latentes produzidas por Phyllosticta citricarpa em frutos de tangerina "Rio". Fitopatologia Brasileira, v.16, p.34, 1991. Suplemento. /Apresentado ao 24., Congresso Brasileiro de Fitopatologia, Rio de Janeiro, 1991. - Resumo/ 
GÓES, A. de; GRAÇA, J.; BARROS, J. M. de; PINHEIRO, J. E. Controle da pinta preta em frutos de tangerina "Rio"(Citrus deliciosa) ocasionada por Phyllosticta citricarpa. Fitopatologia Brasileira, v.13, p.122. 1988 Suplemento. /Apresentado ao 21., Congresso de Fitopatologia, Salvador, 1988. - Resumo/

GÓES, A. de; GRAÇA, J.; BARROS, J. C. S. M; PINHEIRO, J. E. Controle da pinta preta em frutos de tangerina Rio (Citrus deliciosa) ocasionada por Phyllosticta citricarpa (Guignardia citricarpa). Fitopatologia Brasileira, v.15, p.73-5, 1990.

GOMES, F. P. Curso de estatística experimental. 11. ed. Piracicaba: ESALQ, 1985. 466p.

GÖRLACH, J.; VOLRATH, S.; KNAUF-BEITER, G.; HENGY, G.; BECKHOVE, U.; KOGEL, K.-H.; OOSTENDOPR, M.; STAUB, T.; WARD, E.; KESSMANN, H.; RYALS, J. Benzothiadiazole, a novel class of inducers of systemic acquired resistance, activates gene expression and disease resistance in wheat. The Plant Cell, v. 8, p. 629-643, 1996.

GRISEBACH, H. Lignins. In: STUMF, P. K.; CONN, E. E. (Ed.). The biochemistry of plants. New York: Academic Press, 1981. p. 457-478.

GROVER, R. K. Participation of host exudate chemicals in appressorium formation of Colletotrichum piperatum. In: PREECE, T. F.; DICKINSON, C. $\mathrm{H}$. (Ed.). Ecology of leaf surface microorganisms. London: Academic Press, 1971. p. 509-518.

HAHLBROCK, K.; SCHELL, D. Physiology and molecular biology of phenylpropanoid metabolism. Annual Review of Plant Physiology and Plant Molecular and Biology, v. 40, p. 347-369, 1989.

HAMMERSCHMIDT, R. Induced resistance: how do induced plant stop pathogens ? Physiological and Molecular Plant Pathology, v. 55, p. 7784, 1999.

HAMMERSCHMIDT, H.; DANN, E. K. Induced resistance to disease. In: RECHCIGL, N. A.; RECHCIGL, J. E. (Ed.) Environmentally safe approaches to crop disease control. Boca Raton: CRC Lewis Pub., 1997. cap. 8, p.177-199.

HAMMERSCHMIDT, R.; KUC, J. Lignification as a mechanism for induced systemic resistance in cucumber. Physiological Plant Pathology, v. 20, p.61-71, 1982. 
HAMMERSCHMIDT, R.; KUC, J. Induced resistance to disease in plants. Dordrecht: Kluwer Academic, 1995. 182p.

HAMMERSCHMIDT, R.; ACRES, S.; KUC, J. protection of cucumber against Colletotrichum lagenarium and Cladosporium cucumerinum. Phytopathology, v .66, p. 790-793, 1976.

HARBORNE, J. B. Biochemistry of phenolic compounds. London: Academic Press, 1964. 618p.

HARBORNE, J. P. Phytochemical methods: a guide to modern techniques of plants analysis. 3 ed. London: Chapman \& Hall, 1998. 302 p.

HARDING, V. K.; HEALE, J. B. Isolation and identification of the antifungal compounds accumulating in the induced resistance of carrot root slices to Botrytis cinerea. Physiological and Molecular Plant Pathology, v. 17, p.277-289, 1980.

HARPER, D. B.; SWINBURNE, T. R. 2,3-dihydroxy-benzoic acid and related compounds as stimulus of germination of conidia of Colletotrichum musae (Ber. \& Curt) Arx. Physiological Plant Pathology, v. 14, p.363-370, 1979.

HARPER, D. B.; SWINBURNE, T. R.; MOORE, S. K.; BROWN, A. E.; GRAHAM, $\mathrm{H}$. A role for iron in germination of conidia of Colletotrichum musae. Journal of General Mycrobiology, v. 121, p. 169-174, 1980.

HARTUNG, J. S.; BURTON, C. L.; RAMSDELL, D. C. Epidemiological studies of blue-berry antracnose disease caused by Colletotrichum gloeosporioides. Phytopathology, v. 71, p. 449-453, 1981.

HATTORI, S.; M. SHIMOKORIYAMA; M. KANAO. Studies on flavanone glycosides. IV. The glycosides of ripe fruit peel and flower petals of Citrus aurantium L. Journal of the American Chemical Society, v. 74, p. 36143615, 1952.

HAYWARD, A. C. Latent infections by bacteria. Annual Review of Phytopathology, v. 12, p.87-94, 1974.

HEATH, M. C. Reactions of non-suscepts to fungal pathogens. Annual Review of Phytopathology, v.18, p.211-236, 1980.

HENZ, G. P. Doenças de pós-colheita de hortaliças. Fitopatologia Brasileira, v.27, p.14-16, 2002. 
HERBERT, J. A.; GRENCH, N. M. A strain of Guignardia citricarpa, the black spot pathogen, resistant to benomyl in South Africa. Plant Disease, v. 69, p. p. $1007,1985$.

HIPSKIND, J.; HANAU, R.; LEITE, B.; NICHOLSON, R.L. Phytoalexin accumulation in sorghum: identification of an apigeninidin acyl ester. Physiological and Molecular Plant Pathology, v. 36, p.381-396, 1990.

HOROWITZ,R.M. The citrus flavonoids. In: SINCLAIR,W.B. (Ed.). The orange: its biochemistry and physiology. Riverside: University of California, 1961. cap.11, p. 334-372.

HOWARD, R. J.; FERRARI, M. A. Role of melanin in appressorium function. Experimental Mycology, v.13, p. 403-418, 1989.

IPPOLITO, A.; NIGRO, F. Impact of preharvest application of biological control agents on postharvest diseases of fresh fruits and vegetables. Crop Protection, v. 19, p. 715-723, 2000.

ISHII, H.; TOMITA, Y.; HORIO, T.; YOSHIHIRO, N.; NAKASAWA, Y.; NISHIMURA, K.; IWAMOTO, S. Induced resistance of acibenzolar-Smethil (CGA 245704) to cucumber and Japanese pear diseases. European Journal of Plant Pathology, v. 105, p. 77-85, 1999.

JACOBS, A. K.; DRY, I. B.; ROBINSON, S. P. Induction of different pathogenesis-related cDNAs in grapevine infected with powdery mildew and treated with ethefon. Plant Pathology, v. 48, p. 325-336, 1999.

JACOBS, M.; RUBERY, P. H. Naturally occurring auxin transport regulators. Science, v. 241, p.346-349, 1988.

JAHNEN, W.; HAHLBROCK, K. Cellular localization of nonhost resistance reactions of parsley (Petroselium crispium) to fungal infection. Planta, v. 173, p. 197-204, 1988.

JANISIEWICZ, W. J. Ecological diversity, niche overlap, and coexistance of antagonist used in developing mixtures for biocontrol of postharvest diseases of apples. Phytopathology, v. 86, p. 473-479, 1996.

JANISIEWICZ, W, J. Biocontrol of postharvest diseases of temperate fruits. Challenges and opportunities. In: BOLAND, G. J.; KUYKENDALL, L. D. (Ed.). Plant-microbe interactions and biological control. New York: Marcel Dekker, 1998. p.171-197. 
JI, C.; KUC, J. Antifungal activity of cucumber $\beta$-1,3-glucanase and chitinase. Physiological and Molecular Plant Pathology, v. 49, p. 257-265, 1996.

JOHNSON, G. I.; MEAD, A. J.; COOKE, A. W.; DEAN, R. J. Mango stem end rot pathogen infection levels between flowering and harvest. Annals of Applied Biology, v. 119, p.465-473, 1991.

JULKUNEN-TIITTO, R. Phenolic constituents in the leaves of northern willows: methods for the analysis of certain phenolics. Journal of Agricultural and Food Chemistry, v. 33, p. 213-217, 1985.

KALIX, S.; ANFOKA, G.; LI, Y.; STADNIK, M.; BUCHENAUER, H. Induced resistance in some selected crops - prospects and limitations. In: LYR, R.; RUSSEL, P.E.; SISLER, H.D. (Ed.). Modern fungicides and antifungal compounds. Andover: Intercept, 1996. cap.56, p. 451-460.

KARIBA, R. M.; SIBOE, G. M.; DOSSAJI, S.F. In vitro antifungal activity of Schizozygia coffaeoides bail. (Apocynaceae) extracts. Journal of Ethnopharmacology, v. 74, p. 41-4, 2001.

KAUL, T. N.; MIDDLETON, E.; OGRA, P. L. Antiviral effects of flavonoids on human viruses. Journal of Medical Virology, v. 15, p.71-74, 1985.

KESSMANN, H.; STAUB, T.; HOFMANN, C.; MAETZKE, T.; HERZOG, J. Induction of systemic acquired disease resistance in plants by chemicals. Annual Review of Phytopathology, v. 32, p. 439-459, 1994.

KHAN, J. A.; VERNENGHI, A.; RAVISE, A. Incidence of fosetyl Al and elictors on the defence reactions of citrus attacked by Phytophthora spp. Fruits, v.41, p.587-595, 1986.

KLOTZ, L. J. Color hanbook of citrus disease. 4. ed. Berkeley: University of California, Division of Agricultural Sciences, 1973.122 p.

KLOTZ, L. J. Fungal, bacteria and non-parasitic diseases and injuries originating in the seed, nursery, and orchard. In: REUTHER, W.; CALAVAN, E. C.; CARMAN, G. E. (Ed.). The citrus industry. Riverside: University of California, 1978. p.1-66.

KNOESTER, L.; De JAGER, E. S.; De VILLIERS, E. E.; LOURENS, A.; KOTZÉ, J.M.; WHENER, F.C. Evaluation of bacterial epiphytes isolates from avocado leaf and fruits surfaces for biocontrol of avocado postharvest diseases. Plant Disease, v. 79, p.1149-1156, 1995. 
KNOESTER, M.; PIETERSE, C. M. J.; BOL, J. F.; VAN LOON, L. Systemic resistance in Arabidopsis induced by rhizobacteria requires ethylenedependent signaling at the site of application. Molecular Plant-Microbe Interactions, v. 12, p. 720-727, 1999.

KOLATTUKUDY, P. E.; ROGERS, L. M.; LI, D.; HWANG, C.; FLAISHMAN, M. A. Surface signaling in pathogenesis. Proceedings of the National Academy of Science of the United States of American, v. 92, p. 40804087, 1995.

KOOMEN, I.; JEFFRIES, P. Effects of antagonistic microrganisms on postharvest development of Colletotrichum gloeosporioides on mango. Plant Pathology, v. 42, p. 230-237, 1993.

KOTZÉ, J. M. Epidemiology and control of citrus black spot in South Africa. Plant Disease, v. 65, p. 945-950, 1981.

KOTZÉ,J. M. History and epidemiology of Citrus Black Spot in South Africa. Proceedings of International Society of Citriculture, v. 2, p.1296-1299, 1996.

KOZOLOWISKI, G.; BUCHALA, A.; METRAUX, J.P. Methyl jasmonate protects Norway spruce [Picea abies (L.) Karst.] seedlings against Pythium ultimum Trow. Physiological and Molecular Plant Pathology, v. 55, p. $53-58,1999$.

KRANZ, J. Comparison of epidemics. Annual Review of Phytopathology, v.12, p. 355-374, 1974.

KRANZ, J. Comparative anatomy of epidemics. In: HORSFALL,J.G.; COWLING,E.B. (Ed.). Plant disease and advanced treatise. New York: Academic Press, 1988. v. 2, p. 33-62.

KRETZSCHMAR, A. A. Controle biológico de patógenos que ocorrem em pós-colheita. In: BETTIOL,W. (Ed.). Controle biológico de doenças de plantas. Jaguariúna:EMBRAPA, CNPDA, 1991. cap. 5, p 53-69.

KUC, J. Systemic induced resistance. In: WALTERS, D. R.; SCHOLES, J. D.; BRYSON, R.J.; PAUL, N.D.; MCROBERTS, N. (Ed.) Physiological responses of plants to pathogens. Dundee: Association of Applied Biologists, 1995. p. 235-242. (Aspects of applied biology, 42).

KUROSAKI, F.; TASHIRO, N.; NISHI..A. Induction of chitinase and phenylalanine ammonia lyase in cultured carrot cells treated with fungal mycelial walls. Plant Cell Physiology, v. 27, p. 1587-1591, 1986. 
LABANCA, E. R. G. Purificação parcial de elicitores presentes em Saccharomyces cerevisiae: atividade como indutores de resistência em pepino (Cucumis sativus) contra colletotrichum lagenarium e da síntese de gliceolinas em soja (Glycine max). Piracicaba, 2002. 107p. Dissertação (Mestrado) - Escola Superior de Agricultura "Luiz de Queiroz", Universidade de São Paulo.

LAKS, P. E.; M. S. PRUNER. Flavonoid biocides: structure/activity relations of flavonoid phytoalexin analogues. Phytochemistry, v. 28, p.87-91, 1989.

LANTUNDE-DADA, A. O.; LUCAS, J. A. The plant defence activator acibenzolar-S-Methyl primes cowpea [Vigna unguiculata (L.) Walp.] seedlings for rapid induction of resistance. Physiological and Molecular Plant Pathology, v.58, p. 199-208, 2001.

LAWTON, M. A.; LAMB, C. J. Transcriptional activation of plant defense genes by fungal elicitor, wounding and infection. Molecular Cellular and Biology, v. 7, p. 335-341, 1987.

LEITE, B.; NICHOLSON, R. L. Mycosporine-alaline: a self-inhibitor of germination from the conidial mucilage of Colletotrichum graminicola. Experimental Mycology, v.16, p. 76-86, 1992.

LIMA, G.; POLITO, A.; NIGRO, F.; SALERMO, M. Effectiveness of Aureobasidium pullulans and Candida oleophila against postharvest rots. Postharvest Biology and Technology, v. 10, p.169-178, 1997.

LIU, R.; LI, H. F.; SHEN, C. W. F. Detection of pathogenesis related proteins in cotton plants. Physiological and Molecular Plant pathology, v. 47, p. 357-363, 1995.

LO, L.C.; WEIERGANG, I.; BONHAM, C.; HIPSKIND, J.; WOOD, K.; NICHOLSON, R.L. Phytoalexin accumulation ins sorghum: identification of a methyl ether of luteolinidin. Physiological and Molecular Plant Pathology, v. 49, p. 21-31, 1996.

LOPEZ, A. M. Q. Controle alternativo da antracnose causada por Colletotrichum graminicola (Ces.)Wils. em sorgo (Sorghum bicolor L.(Moench). Rio Claro, 1991. 203 p. Disssertação (Mestrado) - Faculdade Estadual Paulista " Júlio de Mesquita.

LOPEZ, A. M. Q.; PASCHOLATI, S. F. Accumulation of a complex of pigments in sorghum mesocotyls in response to wounding. Journal of Phytopathology, v.135, p. 63-70, 1992. 
LUCS, J. A. Plant immunisation: from myth to SAR. Pesticide Science, v. 55, p. 193-196, 1999.

LYON, G. D.; REGLISKI, T.; NEWTON, A. C. Novel disease compounds: the potential to 'immunize' plants against infection. Plant Pathology, v.44, p.407-427, 1995.

MACE, M. E. Histochemical localization of phenols in healthy and diseased banana roots. Physiologia Plantarum, v. 16, p. 915-925, 1963.

MACE, M. E.; BELL, A. A.; STIPANOVIC, R. D. Histochemical and identification of flavanols in Verticillium wilt-resistance and susceptible cottons. Physiological Plant Pathology, v. 13, p. 143-149, 1978.

MACE, M. E.; HOWELL, C. R. Histochemistry and identification of condensed tannin precursors in the roots of cottons seedlings. Canadian Journal of Botany, v. 52, p. 245-247, 1974.

MADIGAN, T.; MARTINKO, J. M.; PARKER, J. Brock biology of microorganisms. 9. ed. New Jersey: Pretince-Hall, 2000. cap. 4, p.102134.

MAGNANI, R. F.; RODRIGUES FILHO, E.; CARDOSO FILHO, J. A. ; PASCHOLATI, S. F. Estudos visando a obtenção de inibidores de Guignardia citricarpa, fungo causador da patogenia "Pinta-Preta" em Citrus In: 25 a REUNIÃO ANUAL DA SOCIEDADE BRASILEIRA DE QUÍMICA, 25., Poços de Caldas, 2002. Resumos. Poços de Caldas: SBQ, 2002. p.134.

MANGOLD, H. K.; SCHMID, H. H. O. STAHL, E. Thin-layer chromatography (TLC). Methods of biochemical analysis, v.12, p. 394-451, 1964.

MARTEN,U.; KNEUSEL, R.E. The phenolic compounds in plant resistance. Phytoparasitica, v. 16, p.153-170, 1988.

MARTINS, E. M. F.; ROVERATTI, D. S.; MORAES, W. B. C. Elicitation of stress metabolites in coffee leaves by a non-pathogen. Fitopatologia Brasileira v.11, p. 683-695, 1986.

MATTOS, F. J. A. Introdução à fitoquímica experimental. Fortaleza: Coleção Ciência, 1988. 126p.

MAUCH-MANI, B.; METRAUX, J.P. Salicylic acid and systemic acquired resistance to plant pathogen attack. Annals of Botany, v. 82, p.535-540, 1998. 
MCCRACKEN, A. R.; SWINBURNE, T. R. Effect of bacteria isolated from surface of banana fruits on germination of conidia Colletotrichum musae (Berk. And Curt.) Arx. Transactions of the British Mycological Society, v. 74, p.212-213,1980.

MCCRACKEN,A.R.,;SWINBURNE,T.R. Siderophores produced by saprophytic bacteria as stimulated of germination of conidia of Colletotrichum musae. Physiological Plant Pathology, v.15, p.331-340, 1979.

MCONIE, K. C. The latent occurrence in citrus and others hosts of a Guignardia easiluy confused with $G$. citricarpa, the citrus black spot pathogens. Phytopathology, v. 54, p. 40-43, 1964.

MCONIE, K. C. Germination and infection of citrus by ascospores of Guignardia citricarpa in relation to control of black spot. Phytopathology, , v. 57, p. 743-746, 1967.

MILLAR,R.L.; HIGGINS,V.J. Association of cyanide with infection of birsfoot trefoil by Stemphylium loti. Phytopathology, v.60, p.104-110, 1970.

MIZUNO, M.; MATOBA, Y.; TANAKA, T. Two new flavones in Citrus reticulata. Journal of Natural Products, v. 50, p.751-753, 1987.

MOHR, U.; LANGE,J .; BOLLER, T.; WEMKEN, A.; VOGELI-LANGE, R. Plant defence genes are induced in the pathogenic interaction between bean roots and Fusarium solani, but not in the symbiotic interaction with the arbuscular mycorrhizal fungi Glomus mosseae. New Phytologist, v.138, p. 589-598, 1998.

MORAES, M. G. Mecanismos da resistência sistêmica adquirida em plantas. Revisão Anual de Patologia Vegetal, v.6, p. 261-284, 1998.

MORAN, P.J.; CIPOLLINI, D.F. Effect of wind-induced mechanical stress on solube peroxidase activity and resistance to pest in cucumber. Journal of Phytopathology, v. 147, p.313-316, 1999.

MUIRHEAD, I. F. The role of appressorial dormancy in latent infections. In: BLAKEMAN, J. P. (Ed.). Microbial Ecology of the Phylloplane. London: Academic Press, 1981. p. 155-167.

MUSUMECI,M.R.;OLIVEIRA,A.R. Accumulation of phenols and phytoalexins in citrus tissues inoculated with Phytophthora citrophthora. Summa Phytothologica, v. 1, p. 275-282, 1975. 
NAKATANI, N.; YAMADA, Y; FUWA, H. 7-Geranyloxycoumarin from juice oil of hassaku (Citrus hassaku) and antimicrobial effects of related coumarins. Agricultural and Biological Chemistry, v. 51, p.419-423, 1987.

NELLY, E. Q.; SAMPIETRO, A .R.; VATTUONE, M. A. Screening antifungal activities of selected medicinal plants. Journal of Ethnopharmacology, v.74, p. 89-96, 2001.

NICHOLSON, R. L.; HAMMERSCHMIDT, H. Phenolic compounds and their role in disease resistance. Annual Review of Phytopathology, v. 30, p. 369-389, 1992.

NICHOLSON, R. L.; KOLLIPARA, S. S.; VINCENT, J. R.; LYONS, P.C.; CADENA-GOMEZ, G. Phytoalexin synthesis by the sorghum mesocotyl in response to infection by pathogenic and nonpathogenic fungi. Proceedings of the National Academy Science of United States of American, v. 84, p. 5520-5524, 1987.

NIDERMAN, T.;GENETET,I. BRUERE,T.; GEES,R.; STINTZI, A.; EGRAND,M.; FRITIG, B.; MOZINGER, E. Pathogenesis-related PR1 proteins are antifungal. Plant Physiology, v.108, p.17-25, 1995.

NIEMAN, G. J.; VAN DER B. I.J. A.; BRANDT-DE BOER, B.; BOON, J. J.; BAAYEN, R.P. Differential response of four carnation cultivars to races 1 e 2 of Fusarium oxysporum f.sp. dianthi and to Phialophora cinerescens. Physiological and Molecular Plant Pathology, v. 38, p.117-136, 1991a.

NIEMANN, G. J.; VAN DER KERK, A.; NIESEN, M. A.; VERSLUIS, K . Free and cell wall-bound phenolics and others constituents from healthy and fungus infected carnation (Dianthus caryopjyllus L.) stems. Physiological and Molecular Plant Pathology, v. 38, p. 417-432, $1991 \mathrm{~b}$.

NORONHA,M.A. de Escala diagramática para a avaliação da mamcha preta em folhas de citros e efeito da temperatura e da duração do molhamento na pré-penetração de conídios de Guignardia citricarpa Kiely [Phyllosticta citricarpa (McAalp.) Van der Aa]. Piracicaba, 2003. 67p. Dissertação (Mestrado) - Escola Superior de Agricultura "Luiz de Queiroz", Universidade de São Paulo.

OGALLO, J. L.; MCCLURE, M. A. Systemic acquired resistance and susceptibility to root-knot nematodes in tomato. Phytopathology, v. 86, p.498-501, 1996. 
PAJOT, E.L.E.; CORRE, D.; SILUE, D. Phytogard® and DL-B-amino butyric acid (BABA) induce resistance to downy mildew (Bremia lactucae) in lettuce (Lactuca sativa L). European Journal of Plant Pathology, v. 107, p. 861-869, 2001.

PANDEY, R. R.; ARORA, D. K.; DUKEY, R. C. Antagonistic interactions between fungal pathogens and phylloplane fungi of guava. Mycopathologia, v. 124, p. 31-39, 1994.

PASCHOLATI, S. F. Potencial de Saccharomyces cerevisiae e outros agentes bióticos na proteção de plantas contra patógenos. Piracicaba, 1998. 123p. Tese (Livre-Docência) - Escola Superior de Agricultura "Luiz de Queiroz", Universidade de São Paulo.

PASCHOLATI, S. F.; LEITE, B. Mecanismos bioquímicos da resistência as doenças. Revisão Anual de Patologia Vegetal, v. 2, p.1-51,1994.

PASCHOLATI, S. F.; LEITE, B. Hospedeiro: mecanismos de resistência. In: BERGAMIN FILHO, A.; KIMATI, H.; AMORIM, L. (Ed.). Manual de fitopatologia: princípios e conceitos. 3. ed. Piracicaba: Agronômica Ceres, 1995. cap. 22, p. 417-453.

PASCHOLATI, S. F.; HEIM, D.; NICHOLSON, R. L. Phenyalalanine ammonia lyase and susceptible of the maize mesocotyl to Helminthosporium maydis. Physiological Plant Pathology, v. 95, p. 34556, 1985.

PASCHOLATI, S. F.; NICHOLSON, R. L.; BUTLER, L.G. Phenylalanine ammonia lyase activity and anthocyanin accumulation in wounded maize mesocotyls, Journal of Phytopathology, v.1 15, p. 165-172, 1986.

PASCHOLATI, S. F.; STANGARLIN, J. R.; HOTO, F. V.; PICCININ, E.; OSSWALD, W. Efeito in vitro do ativador de defesa vegetal "Bion" no crescimento micelial e na germinação de conídios de Colletotrichum graminicola. Fitopatologia Brasileira, v. 23, p. 266-267, 1998

PEREZ, J. O. Caracterização de isolados de Crinipelis perniciosa, indução de resistência àvassora-de-bruxa no cacaueiro e análise de peroxidases na interação planta-patógeno. Lavras, 2002. 81p. Tese (Doutorado) Universidade Federal de Lavras. 
PICCININ, E. Uso de Saccharomyces cerevisiae na proteção de plantas de sorgo (Sorghum bicolor), maracujá azedo amarelo (Passiflora edulis) e eucalipto (Eucalyptus spp.) contra fitopatógenos fúngicos e bacterianos. Piracicaba, 1995. 107 p. Dissertação (Mestrado) - Escola Superior de Agricultura "Luiz de Queiroz", Universidade de São Paulo.

PODILIA, G. K.; ROGERS, L. M.; KOLATUKKUDY, P. E. Chemicals signals from avocado surface wax trigger germination and apressorium formation in Colletotrichum gloesporioides. Plant Physiology, v.103, p. 267$272,1993$.

POLLACK, S. Forecast for citrus: a mixed bag growers. Agricultural Outlook, n. 287, p. 2-4, 2001.

PRATES, H. S.; NOGUEIRA, N. L. Controle químico da pinta preta (Phyllosticta citricarpa) em laranjeiras pêra. In: CONGRESSO PAULISTA DE FITOPATOLOGIA, 20. São Paulo, 1996. Programas e resumos. São Paulo: Grupo Paulista de Fitopatologia, 1996. p. 89.

PRUSKY, D.; FREEMAN, S.; RODRIGUEZ, R. J.; KEEN, N. T. A nonpathogenic mutant strain of Colletotrichum magna induces resistance to C. gloeosporioides in avocado fruits. Molecular Plant-Microbe Interactions, v.7, p. 326-333, 1994.

PRUSKY,D. Pathogen quiescence in postharvest diseases. Annual Review of Phytopatholgy, v. 34, p. 413-434, 1996.

PURKAYASTHA, R. P. Progress in phytoalexin research during the past 50 years. In: DANIEL, M.; PURKAYASTHA, R.P. (Ed.). Handbook of Phytoalexin metabolism and action. New York: Marcel Dekker, 1995. p.1-39.

QASEM, J. R.; ABU-BLAN, H. A. Fungicidal activity of some weed extracts against different plant pathogenic fungi. Journal of Phytopathology, $v$. 144, p. 157-161, 1996.

QUIROGA, E. N.; SAMPIETRO, A. R.; VATTUONE, M. A. Screening antifungal activities of selected medicinal plants. Journal of Ethnopharmacology, v. 74, p. 89-96, 2001.

RESENDE, M. L.; NOJOSA, G. B. A.; AGUILAR, M. A. G.; SILVA, L. H. C. P.; NIELLA, G. R.; CARVALHO, G. A.; GIOVANNI, G. R.; CASTRO, R. M. Perspectiva da indução de resistência em cacaueiro contra Crinipellis perniciosa através do benzotiadiazole (BTH). Fitopatologia Brasileira, v. 25, p. 149-156, 2000. 
RIBEIRO, L. F.; BEDENDO, I. P. Efeito inibitório de extratos vegetais sobre Colletotrichum gloeosporioides - agente causal da podridão dos frutos de mamoeiro. Scientia Agricola, v. 56, p. 1267-1271, 1999.

RIBÉREAU-GAYON, P. Plant phenolics. Edinburgh: Oliver \& Boyd, 1972. $247 p$.

ROBARDS, K.; PRENZLER, P. D.; TUCKER, G.; SWATSITANG, P.; GLOVER, W. Phenolics compounds and their role in oxidative processes in fruits. Food Chemistry, v. 66, p.401-36, 1999.

ROBBINS, R. Medical and nutritional aspects of citrus bioflavonoids. In: NAGY, S.; ATTAWAY, J. (Ed.). Citrus nutrition and quality. Washington: American Chemistry Society, 1980. p. 43-59.

ROBBS, C. F. A mancha preta dos frutos cítricos (Phyllosticta citricarpa) ameaça a citricultura paulista. Laranja, v. 11, p. 75-86, 1990.

ROBERTS, R. G. Integrating biological control into postharvest disease management strategies. HortScience, v. 29, p. 758-762, 1994.

RODOV,S.;BEN-YEHOSHUA,D.;D'HALLEWIN,G.;CASTIA,T. Accumulation of phytoalexins scoparone and scopoletin in citrus fruits subjected to various postharvest treatments. Acta Horticulture, n. 381, p. 517-523, 1994.

RODRIGUEZ, R. J.; REDMAN, R. S. Fungal life-styles and ecosystem dynamics: biological aspects of plant pathogens, plant endophytes and saprophytes. Advances in Botanical Research, v. 24, p.169-193, 1997.

RONCATTO, M.C.; PASCHOLATI, S. F. Alterações na atividade e no perfil eletroforético da peroxidase em folhas de milho (Zea mays) e sorgo (Sorghum bicolor) tratadas com Saccharomyces cerevisiae. Scientia Agricola, v. 55, p. 395-402, 1998.

ROVERATTI, D.S. Proteção de plantas de café (Coffea arabica L.) contra Hemileia vastatrix Berk. et Br. por Saccharomyces cerevisiae. Piracicaba, 1989. 94p. Dissertação (Mestrado)-Escola Superior de Agricultura "Luiz de Queiróz", Universidade de São Paulo.

RYALS, J. A.; NEUENSCHWANDER, U. H.; WILLITS, M. G.; MOLINA, A.; STEINER, H. Y.; HUNT, M. Systemic acquired resistance. Plant Cell, v. 8, p. 1809-1819, 1996. 
SAFASCIENCE http://www.safascience.com./agriculture/eleaxasmart.html. (20 dez. 2002).

SCHONBECK, F.; SCHLOSSER, E. Preformed substances as potential protectants. In: HEITEFUS,R.; WILLIANS,P.H. (Ed.). Physiological Plant Pathology. New York: Springer-Verlag, 1976. p. 653-678. (Encyclopedia of Plant Physiology, 4).

SCHRINER, R. L.; FUSON, R. C.; CURTIN, D. Y.; MORRILL, T. C. Identificação sistemática dos compostos orgânico: manual de laboratório. 3. ed. Rio de Janeiro: Guanabara Dois, 1983. 517p.

SCHULZ, F. A. Some physiological and biochemical aspects of the action mechanism of fungal parasites during fruit storage. Fruits, v. 33, p.15-21, 1978.

SEGURA, A.; MORENO, M.; MOLINA, A.; GARCíA-OLMEDO, F. Novel defensin subfamily from spinach (Spinacia oleracea). FEBS-Letters, v.435, p. 159-162, 1998.

SELA-BUURLAGE, M. B.; PONSTEIN, A. S.; BRES-VLOEMANS, S. A; ELCHERS, L S.; VAN DEN ELZEN, P. J. M.; CORNELISSEN, B. J. C. Only specific tobacco (Nicotiana tabacum) chitinases and $\beta-1,3-$ glucanases exhibit antifungal activity. Plant Physiology, v. 101, p. 857863, 1993.

SHERMA, J.; FRIED, B. (Ed.). Handbook of thin-layer chromatography. 2. ed. New York:Marcel Dekker, 1996. 1104p. (Chromatographic Science Series, 71).

SHIRAISHI, T.; YAMAOKA, N.; KUNOH, H. Association between increased phenylalanine ammonia lyase acticity and cinnamic acid synthesis and the induction of temporary inaccessibility caused by Erysiphe graminis primary tube penetration of the barley leaf. Physiological and Molecular Plant Pathology, v. 34, p. 75-83, 1989.

SHULAEV, V.; SILVERMAN, P.; RASKIN, I. Airborne signaling by methyl salicylate in plant pathogen resistance. Nature, v. 385, n.6618, p. 718$721,1997$.

SILVA, L. H. C. P.; RESENDE, M. L. V. de Resistência induzida em plantas contra patógenos. In: SILVA,L.H.C.P. da; CAMPOS, J. R.;NOJOSA, G. B. A. (Ed.). Manejo integrado de doenças e pragas em hortaliças. Lavras: UFLA, 2001. p. 221-234. 
SILVA, S. R.; PASCHOLATI, S. F. Saccharomyces cerevisiae protects maize plants, under greenhouse conditions, against Colletotrichum graminicola. Journal of Plant Disease and Protection, v. 99, p. 159-67, 1992.

SILVERSTEIN, R. M.; BASSLER, G. C. Spectrometric identification of organic compounds. 2. ed. New York: John Wiley, 1967. 256p.

SINCLAIR, J. B. Latent infection of soybean plants and seeds by fungi. Plant Disease, v. 75, p.220-224, 1991.

SINCLAIR, W. The biochemistry and physiology of the lemon and others citrus fruits. Riverside:University of California, 1984 cap. 10, p.409: Citrus flavonoids.

SITTERLY, W. R.; SHAY, J. R. Physiological factors affecting the onset susceptibility of apple fruit to rotting by fungal pathogens. Phytopathology, v. 50, p. 91-93, 1960.

SMITH, C. J. Accumulation of phytoalexins: defence mechanisms and stimulus response system. New Phytologist, v. 132, p.1-45, 1996.

SMITH, D. A. Toxicity of phytoalexins. In: BAILEY, J. A.; MANSFIELD, J.W. (Ed.). Phytoalexins. Glasgow: Blackie, 1982. cap.8, p. 218-252.

SNYDER, B. A.; LEITE, B.; HIPSKIND, J.; BUTLER, L.G.; NICHOLSON, R.L. Accumulation of sorghum phytoalexins induced by Colletotrichum graminicola at the infection site. Physiological and Molecular Plant Pathology, v. 39, p. 463-470, 1991.

SNYDER, B. A.; NICHOLSON, R. L. Synthesis of phytoalexins in sorghum as a site-specific response to fungal ingress. Science, v. 248, p.1637$1639,1990$.

SOMMER, N. F. Postharvest handling practices and postharvest diseases of fruit. Plant Disease, v. 66, p. 357-364, 1982.

SPLETZER, M.; ENYEDI, A. J. Salicylic acid induces resistance to Alternaria solani in hydroponically grown tomato. Phytopathology, v. 89, p. $722-$ 727, 1999.

STANGARLIN, J. R.; PASCHOLATI, S. F. Proteção de plântulas de milho pipoca contra Exserohilum turcicum pelo uso de Saccharomyces cerevisiae. Summa Phytopathologica, v. 20, p. 16-21, 1994. 
STANGARLIN, J. R.; SCHWAN-ESTRADA, K. R. F.; CRUZ, M. E. S.; NOZAKI, $M$. $H$. Plantas medicinais e controle alternativo de fitopatógenos. Biotecnologia Ciência \& Desenvolvimento, n. 11, p. 1621, 1999.

STEIN, B. D.; KLOMPARENS, K.L.; HAMMERSCHMIDT, R. Histochemistry and ultrastructure of the induced resistance response of cucumber plants to Colletotrichum lagenarium. Journal of Phytopathology, v.137, p.177188, 1993.

STELL, R. G. D.; TORRIE, J. H. Principles and procedures of statistics. New York: McGraw-Hill, 1980. 633p.

STEVENS, C.; KHAN, V.A.; LU, J.Y.; WILSON, C.L.; ADEYEYE, O.; PUSEY, L.P.; TANG, A.Y.A. Induced resistance of sweetpotato to Fusarium root rot by UV-C. Crop Protection, v.18, p. 463-470, 1999.

STICHER, L.; MAUCH-MANI, B.; METRAUX, J.P. Systemic acquired resistance. Annual Review of Phytopathology, v.35, p.235-270, 1997.

SUTTON, B. C.; WATERSON, J. M. Guignardia citricarpa. Kew: Commonwealth Mycological Institute, 1966. 2 p. (Descriptions of Pathogenic Fungi and Bacteria, 85).

SWINBURNE, T. R. Stimulus of germination and apressoria formation by Colletotrichum musae (Berk. \& Curt.) Arx. in banana leachate. Phytopathology Zeitschrift, v. 87, p. 74-90, 1976.

SWINBURNE, T. R. Post-infection antifungal compounds in quiescent or latent infections. Annals Applied of Plant Biology, v. 89, p. 322-325, 1978.

SWINBURNE, T. R. Quiescent infections in post-harvest diseases. In: DENNIS, C. (Ed.). Post-Harvest pathology of fruits and vegetables. London: Academic Press, 1983. p.1-21.

TATUM, J.H.; BERRY, R. E. Coumarins and psoralens in grapefruit peel oil. Phytochemistry, v. 18, p. 500-502, 1979.

TEWARI, S. N.; NAYAK, M. Activity of four-plant leaf extracts against three fungal pathogens of rice. Tropical Agriculture, v. 68, p. 373-375, 1991.

TOIT, E. A. du; RAUTENBACH, M. A sensitive standardized micro-gel well diffusion assay for the determination of antimicrobial activity, Journal of Microbiological Methods, v. 42, p. 159-165, 2000. 
TOMAS, F.; O. CARPENA ARTES; R. PASTOR; J. J. MATAIX BENEYETO. Flavonoids in flowers of Citrus limon cv. Eureka. Proceedings of the International Society of Citriculture, v.1, p. 74-76, 1978.

TSURUSHIMA,T.; UENO,T.; FUKAMI, H.; IRIE, H.; INOUE, M. Germination self-inhibitors from Colletotrichum gloesporioides f.sp. jussiae. Molecular Plant Microbe Interactions, v.8, p.652-657, 1995.

UKNESS, S; VERNOOIJ, B.; MORRIS, S.; CHANDLER, D.; STEINER,H. Y.; SPECCKER,N.; HUNT,M.; NEUENSCHAWADER,U.; LAWTON, K.; STARRET,M.; FRIEDRICH,L.; WEYMANN,K.; NEGROTTO, D.; GÖLACH,J.; LANAHAN,M.; SALMERON, J.; WARD,E.; KESSMANN, H.; RYALS,J. Reduction of risk for growers: methods for the development of disease-resistants crops. New Phytologist, v.133, p. 3-10, 1996.

VAN LOON, L.C.; VAN KAMMEN, A. Polyacrylamide disc eletrophoresis of the soluble leaf proteins from Nicotiana tabacum var. "Samsun" and "Samsun NN" Changes in protein constitution after infection with TMV. Virology, v. 40, p.199-211, 1970.

VAN LOON L.C.; BAKKER, P.A.H.M.; PIETERSE, C.M.J. Systemic resistance induced by rhizosphere bacteria. Annual Review of Phytopathology, v.36, p.453-483, 1998.

VAN LOON, L. C.; VAN STRIEN, E. A. The families of pathogenesis-related proteins, their activities, and comparative analysis of PR-1 type proteins. Physiological and Molecular Plant Pathology, v. 55, p. 85-97, 1999.

VANETTEN, H. D.; MANSFIELD, J. W.; BAILEY, J. A.; FARMER, E. E. Two classes of plant antibiotics: phytoalexins versus phytoanticipins. Plant Cell, v. 9, p. 1191-1192, 1994.

VERHOEFF, K. Latent infections by fungi. Annual Review of Phytopathology, v.12, p. 99-110, 1974.

VOGELI, U.; MEINS, F.; BOLLER, T. Co-ordinated regulation of chitinase and $\beta$-1,3-glucanase in bean leaves. Planta, v. 174, p. 364-372, 1988.

WADE, G.C.; CRUIKSHANK, R.H. The establishment and structure of latent infections with Monilinia fructicola on apricots. Journal of Phytopathology, v. 136, p. 95-106, 1992. 
WATANABE, T.; SEKIZAWA, Y.; SHIMURA, M.; SUZUKI, Y.; MATSUMOTO, K.; IWATA, M.; MASE, S. Effects of probenazole (Oryzemate ${ }^{\circledR}$ ) on rice plants with reference to controlling rice blast. Journal of Pesticide Science, v.4, p.53-59, 1979.

WATERMAN, P. G.; MOLE, S. Methods in ecology: analysis of phenolic plant metabolites. Oxford: Blackwell Scientific, 238p. 1994.

WATTAD, C.; DINNOR, A.; PRUSKY, D. Purification of pectato lyase produced by Colletotrichum gloeosporioides and its inhibition by epicatequina: a possible factor involved in the resistance of unripe avocado fruits to anthracnose. Molecular Plant Microbe Interactions, v. 7, p. 293-297, 1994.

WHITESIDE, J. O.;GARNSEY, S. M.;TIMMER, L. W. Compendium of citrus disease. 2.ed. St. Paul: APS Press, 1993.

WIDMER, W. W.; MONTANARI, A. M. Citrus waste streams as a source for phytochemicals. Proceedings of the Florida State for Horticultural Society, v.107, p. 284-288, 1994.

WILSON,C.L.; WISNIEWSKI, M. E. Biological control of postharvest diseases of fruits and vegetables. Annual Review of Phytopathology, v. 27, p. 425-441, 1989.

WILSON, C. L.; WISNIEWSKI, M. E. (Ed.). Biological control of postharvest diseases of fruits and vegetables: theory and practice. Boca Raton: CRC Press, 1994. 425p.

WILSON, C. L.;GHAOUTH, A. E.;CHALUTZ, E.; DROBY, C.; STEVENS, C.;LU, J. Y.; KHAN, V.; ARUL, J. Potential on induced resistance to control postharvest diseases of fruits and vegetables. Plant Disease, $v$. 78, p. 837-844, 1994.

WISNIEWSKI, M. E.; BILES, C. L.; DROBY, S.;McLAUGHLIN, R. J.; WILSON, C. L.; CHALUTZ, E. Mode of action of the posthavest biocontrol yeast Pichia guilliermondii. I. Characterization of attachment to Botrytis cinerea. Physiological Molecular Plant Pathology, v. 39, p. 245-258, 1991.

WISNIEWSKI, M. E.;WILSON, C. L. Biological control of postharvest diseases of fruits and vegetables: recent advances. HortScience, v. 27, p. 94-98, 1992. 
WITTIG,H.P.P.;JOHNSON,K.B.;PSCHEIDT,J.W. Effect of epiphytic fungi on brown rot blossom blight and latent infections in sweet cherry. Plant Disease, v.81,p.383-387, 1997.

WULFF, N.A. Caracterização parcial de elicitores de fitoalexinas em sorgo (Sorghum bicolor) obtidos a partir de Saccharomyces cerevisiae. Piracicaba, 1997. 62p. Dissertação (Mestrado) - Escola Superior de Agricultura "Luiz de Queiroz", Universidade de São Paulo.

WULFF, N. A.; PASCHOLATI, S. F. Preparações de Saccharomyces cerevisiae elicitoras de fitoalexinas em mesocótilos de sorgo. Scientia Agrícola, v. 55, p.138-143, 1998.

WULFF, N. A.; PASCHOLATI, S. F. Partial characterization of sorghum phytoalexin elicitors isolated from Saccharomyces cerevisiae. Fitopatologia Brasileira, v. 24, p. 428-435, 1999.

YAMAOKA, N.; LYONS, P.C.; HIPSKIND, J.; NICHOLSON, R.L. Elicitor of sorghum phytoalexin synthesis from Colletotrichum graminicola. Physiological and Molecular Plant Pathology, v.37, p.255-270, 1990.

YI, S.Y.; HWANG, B.K. Differential induction and accumulation of $\beta-1,3-$ glucanase and chitinase isorforms in soybean hypocotlys and leaves after compatible and incompatible infection with Phytophthora megasperma f. sp. glycinea. Physiological and Molecular Plant Pathology, v. 48, p.179-192, 1996.

YOSHIOKA, K; NAKASHITA, H.; KLESSIG, D. F.; YAMAGUCHI, I. Probenazole induces systemic acquired resistance in Arabidopsis with a novel type of action. The Plant Journal, v. 25, p.149-157, 2001.

ZAAT, S. A. J.; BRUSSEL, A. A. N. VAN; TAK, T. Flavonoids induce Rhizobium leguminosarum to produce nodDABC gene-related factors that cause thick, short roots and root hair responses on common vetch. Journal of Bacteriology, v. 169, p. 3388-91, 1987.

ZAMBONELLI, A.; ZECHINI D' AULERIO, A.; BIANCHI, A.; ALBASIN, A. Effects of essential oils on phytopathogenic fungi in vitro. Journal of Phytopahology, v. 144, p. 491-494, 1996. 


\section{APÊNDICES}


Apêndice 1 - Curva padrão para dosagem de compostos fenólicos pelo método do Reagente de Folin-Ciocalteau.

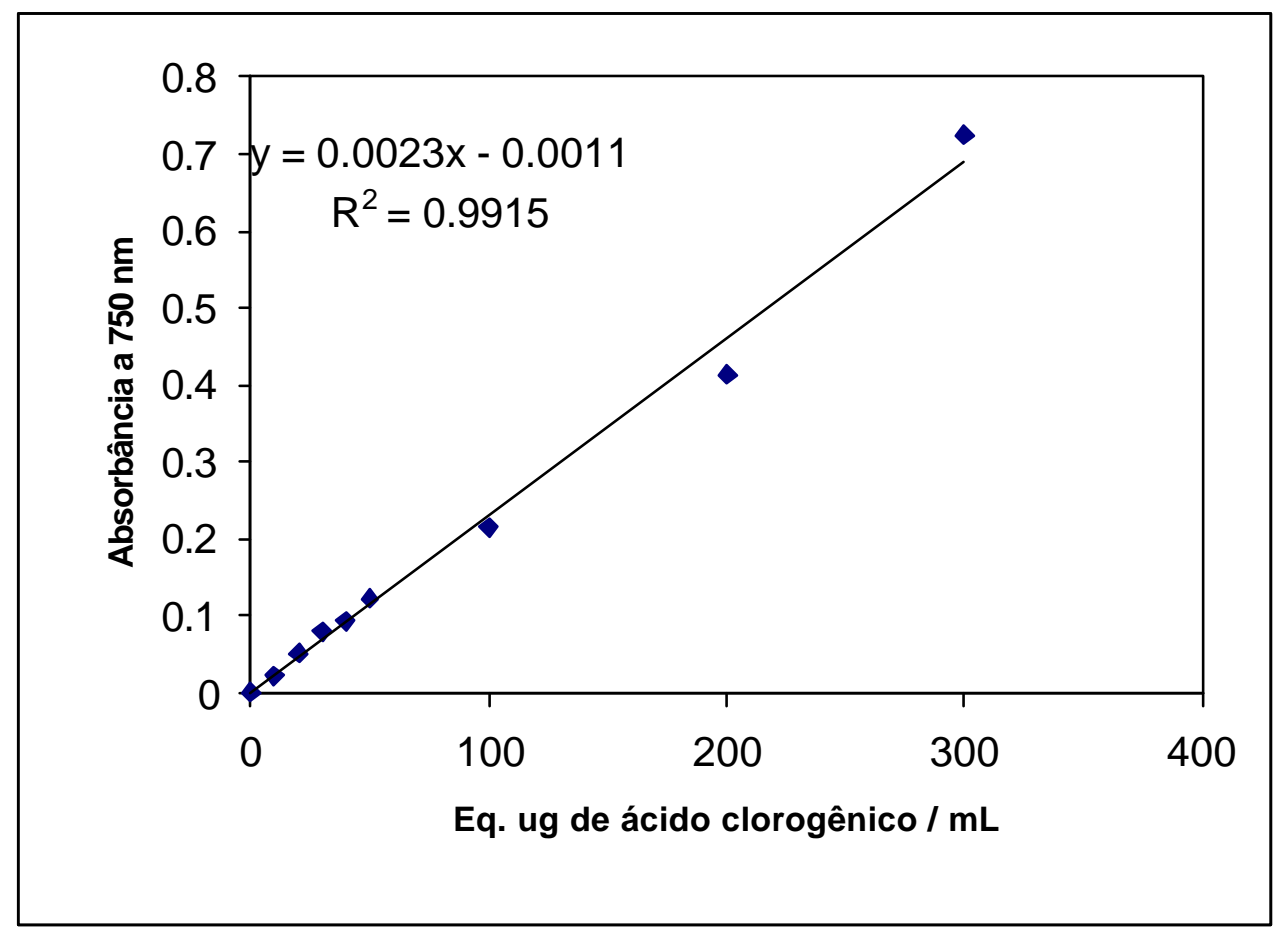


Apêndice 2 - Fluxograma para obtenção de extratos do albedo de laranja Pêra-Rio. $\mathrm{O}$ albedo foi submetido à extração com solventes e mistura dos mesmos visando obter extratos com diferentes polaridades (Magnani et al., 2002). Os extratos foram submetidos àHPLC, espectrometria de massas e RMN${ }^{13} \mathrm{C}$ onde foi identificado o flavonóide glicosilado naringina.

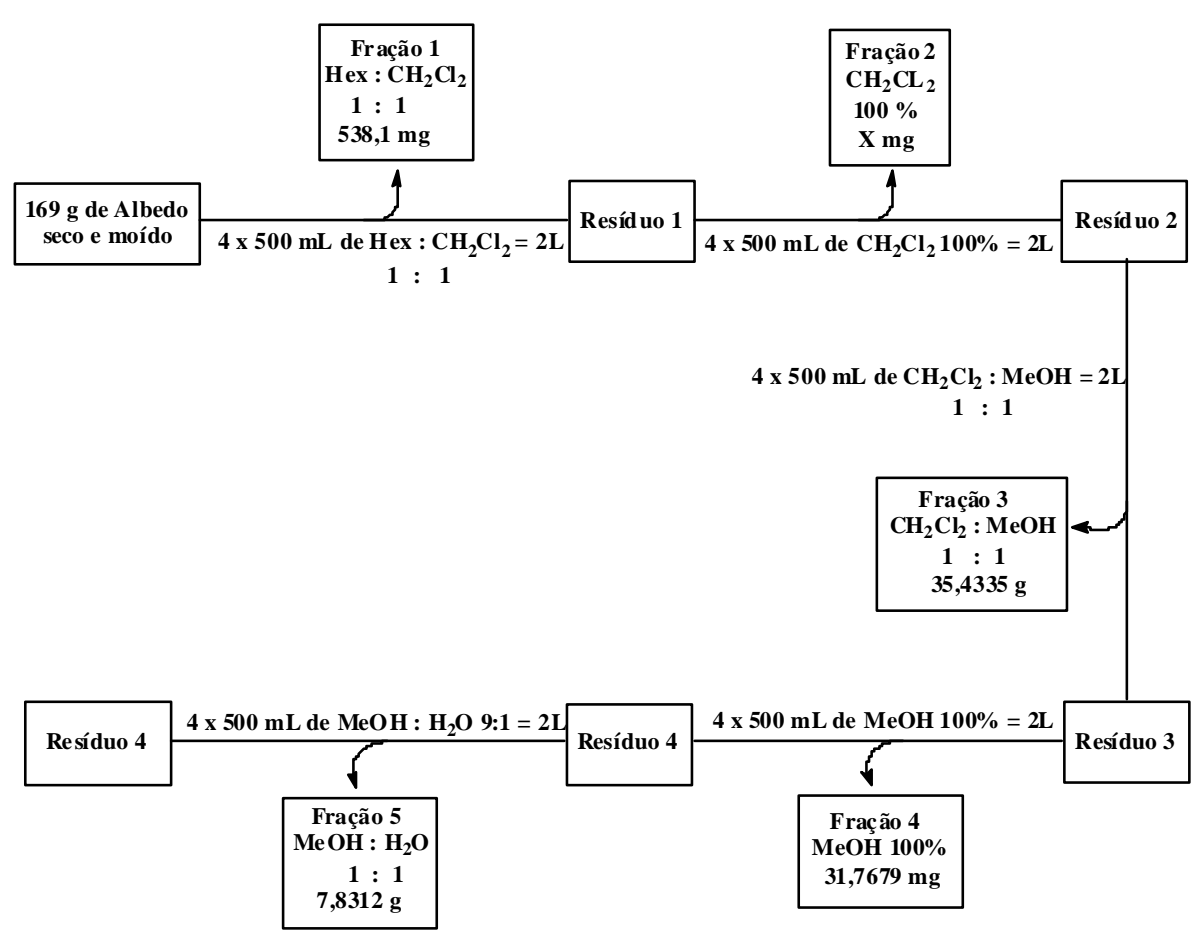


Apêndice 3 - Espéctro de absorção em ultra violeta de eluente de naringina cromatografado em placas de sílica gel $\left(\mathrm{SiO}_{2} \times \mathrm{H}_{2} \mathrm{O} 20 ; 20 \mathrm{~cm} ; \mathrm{G}\right.$ $60 \mathrm{~F}_{250 \mathrm{~nm}}$ (Whatman)) com indicador de luminescência obtido através de cromatrografia de camada delgada (fase móvel butanol, ácido acético, água; 4:1:1; v/v).

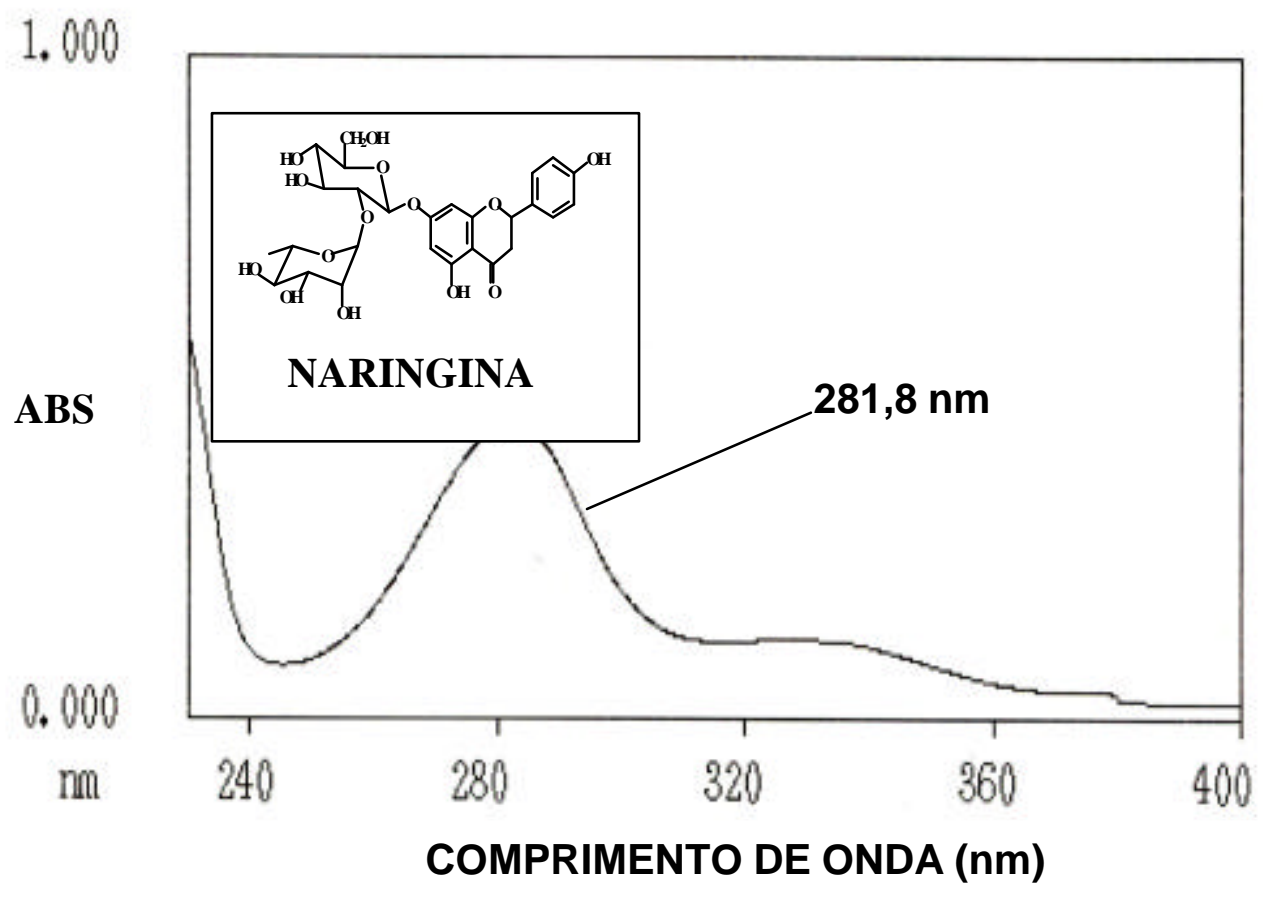


Apêndice 4 - Coeficientes de determinação para os efeitos de indução de resistência de ácido salicílico, Bion e Saccharomyces, cerevisiae, antes e depois do uso de Ethrel, em frutos de laranja (Citrus sinensis, var. Pêra-Rio) sintomáticos e assintomáticos infectados por Phyllosticta citricarpa.

\begin{tabular}{|c|c|c|}
\hline Tratamento & $\mathrm{R}^{2}$ (antes) & $R^{2}$ (depois) \\
\hline $\begin{array}{l}\text { Ácido salicílico } 20 \mathrm{~min} / \\
72 \mathrm{~h} \text { antes }^{1} \text { e depois }\end{array}$ & $0,86 \mathrm{~ns}$ & $0,99 \mathrm{~ns}$ \\
\hline $\begin{array}{l}\text { Ácido salicílico } 3 \text { h / } 72 \\
\text { h antes e depois }\end{array}$ & $0,93 \mathrm{~ns}$ & $0,29 \mathrm{~ns}$ \\
\hline $\begin{array}{l}\text { Ácido salicílico } 6 \text { h / } 72 \\
\text { h antes e depois }\end{array}$ & $0,71 \mathrm{~ns}$ & $0,87 \mathrm{~ns}$ \\
\hline $\begin{array}{l}\text { Ácido salicílico } 10 \text { h / } 72 \\
\text { h antes e depois }\end{array}$ & $0,85 \mathrm{~ns}$ & $0,69 \mathrm{~ns}$ \\
\hline $\begin{array}{l}\text { Bion } 20 \text { min / } 48 \mathrm{~h} \\
\text { antes e depois }\end{array}$ & $0,76 \mathrm{~ns}$ & $0,76 \mathrm{~ns}$ \\
\hline $\begin{array}{l}\text { Bion } 3 \mathrm{~h} / 48 \mathrm{~h} \text { antes e } \\
\text { depois }\end{array}$ & $0,57 \mathrm{~ns}$ & $0,70 \mathrm{~ns}$ \\
\hline $\begin{array}{l}\text { Bion } 6 \mathrm{~h} / 48 \mathrm{~h} \text { antes } \mathrm{e} \\
\text { depois }\end{array}$ & $0,24 \mathrm{~ns}$ & $0,81 \mathrm{~ns}$ \\
\hline $\begin{array}{l}\text { Bion } 10 \mathrm{~h} / 48 \mathrm{~h} \text { antes } \mathrm{e} \\
\text { depois }\end{array}$ & $0,50 \mathrm{~ns}$ & $0,57 \mathrm{~ns}$ \\
\hline $\begin{array}{l}\text { S. cerevisiae } 20 \mathrm{~min} / \\
24 \mathrm{~h} \text { antes e depois }\end{array}$ & $0,88 \mathrm{~ns}$ & $0,48 \mathrm{~ns}$ \\
\hline $\begin{array}{l}\text { S. cerevisiae } 3 \mathrm{~h} / 24 \mathrm{~h} \\
\text { antes e depois }\end{array}$ & $0,98 \mathrm{~ns}$ & $0,61 \mathrm{~ns}$ \\
\hline $\begin{array}{l}\text { S. cerevisiae } 6 \mathrm{~h} / 24 \mathrm{~h} \\
\text { antes e depois }\end{array}$ & $0,80 \mathrm{~ns}$ & $0,42 \mathrm{~ns}$ \\
\hline $\begin{array}{l}\text { S. cerevisiae } 10 \mathrm{~h} / 24 \mathrm{~h} \\
\text { antes e depois }\end{array}$ & $0,95 \mathrm{~ns}$ & $0,81 \mathrm{~ns}$ \\
\hline
\end{tabular}

